\title{
ESTUDO COMPARATIVO DE TRÊS CAPINS DA ESPÉCIE maximum Jacq. (COLONIÃO, TOBIATÃ E K-187 B)
}

\author{
JOAO BATISTA DE ANDRADE
}

Orientador: Dr. JOSE VICENTE SILMEIRA PEDREIRA

Dissertação apresentada ̀̀ Escola Superior Agricultura "Luiz de Queiroz", da Univ de São Paulo, para obtenção do $t$ Mestre em Agronomia - Area de Concent "Nutriçâo Animal e Pastagens".

\author{
PIRACICABA \\ ESTADO DE SÃO PAULO - BRASIL \\ FEVEREIRO - 1987
}


Ao meu pai Fabio de Andrade "in memorian"

e a minha maé Almerinda Gabriel de Andrade,

por terem me dado a vida, amor e o máximo de si pela minha educação e

Aos meus inmãos Antonio, Pedro e Fabio e

$\dot{A}$ minha irmã Almeninda,

pelo respeito e carinho dedicado, ofereço.

$\dot{A}$ minha esposa Neuza Maria, pelo amor que nos une e à Luciana, Lilian e João, frutos desse amor,

dedico. 


\section{AGRADECIMENTOS}

- Ao Eng Agro Dr. José Vicente Silveira Pedreira pelas orientações seguras, ensinamentos e atenção dedicada.

- Ao Engo Agro PhD Joaquim Carlos Werner pela va liosa colaboração e atenção dedicada.

- Ao Engo Agro Gilberto Bufarah, Diretor da Divisão de Nutrição Animal e Pastagens, pelas facilidades concedidas.

- Ao Prof. Dr. José Carlos Barbosa pela execução da análise estatistica.

- Ao Engo Agro M.S = Benedicto do Espirito Santo de Campos, Dra. Eliana Aparecida Schamass e o Estat. Antonio Ál varo Duarte de Oliveira, pela colaboração durante as análises estatisticas.

- Às Seções de Nutrição de Plantas Forrageiras e de Avaliação de Forragens, pelas análises químicas efetuadas.

- Ao Engㅇ Agro PhD Francisco Antonio Monteiro pe la colaboração e atenção dedicada.

- Ao Jorn. Nils Ferdinand Sabey pela revisão do texto deste trabalho.

- Aos Professores do Curso de Pós-graduação de Nutrição Animal e Pastagens, pelos ensinamentos ministrados. 
- Aos Técnicos Agrícolas Senhores Diogēnes Lopes e Hélio Soares do Nascimento, funcionários da Divisão de Nutrição Animal e Pastagens, pela eficiente colaboração durante a execução da fase de campo.

- Aos funcionários dos laboratórios da Divisão de Nutrição Animal e Pastagem, pela realização das análises.

- ̇̀ minha esposa Neuza Maria e aos meus filhos Luciana, Lilian e João pelo sacrifício e compreensão prestados. - Ao meu irmão Pedro e minha cunhada Vera Maria com reconhecimento.

- E a todos aqueles que direta ou indiretamente contribuiram para a realização deste trabalho.

- Ao Instituto de Zootecnia pela facilidades con cedidas.

- À EMBRAPA, Empresa Brasileira de Pesquisa Agro pecuária, pela concessão de bolsa. 
ÍNDICE

Página

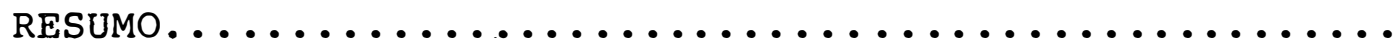
IX

SUMMARY . XII

1. INTRODUÇÃO. 1

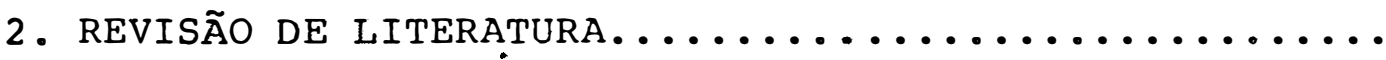

2.1. Informações sobre os capins estudados.........

2.2. Ganho acumulativo de matéria seca...........

2.3. Número de perfilhos por área, peso médio dos perfilhos, relação lâmina:haste, altura da cultura, altura do meristema a-

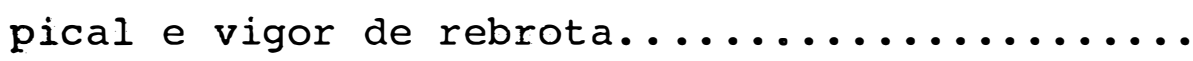

2.4. Teores de matéria seca, fibra bruta, proteína bruta e participação porcentual de proteína bruta contida na lámina e na haste em relação à proteína da planta in-

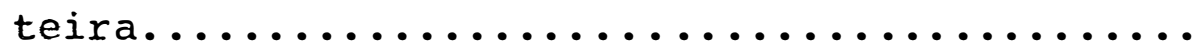

2.5. Teores de conteúdo celular, fibra insolúvel em detergente neutro, fibra insolúvel em detergente ácido, hemicelulose, celulo se, lignina e digestibilidade "in vitro"

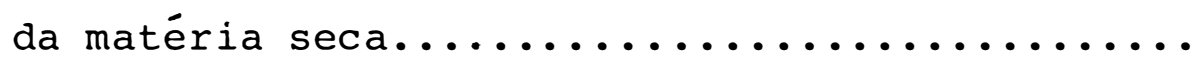

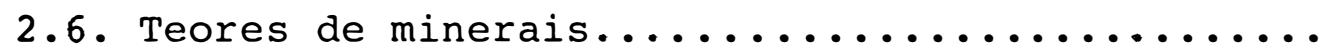

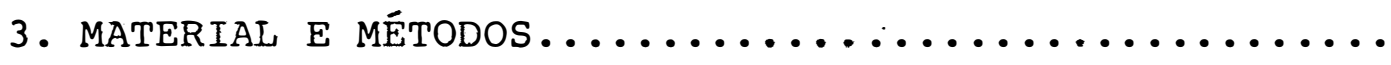


Página

3.1. Crescimento em ganho acumulativo de matéria seca da parte aérea................. 28

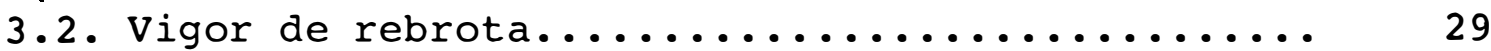

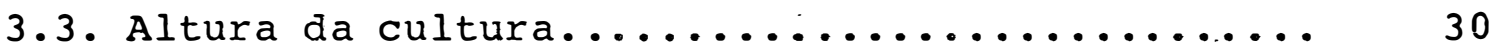

3.4. Número de perfilhos por área e peso médio dos perfilhos................... 30

3.5. Relação lâmina:haste e latura do meris-

- tema apical........................

3.6. Teores de matéria seca, proteína bruta

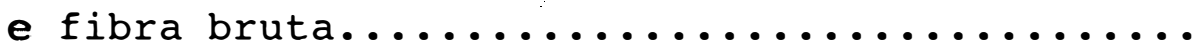

3.7. Participação porcentual de proteína bru ta da lämina e da haste em relaçäo à

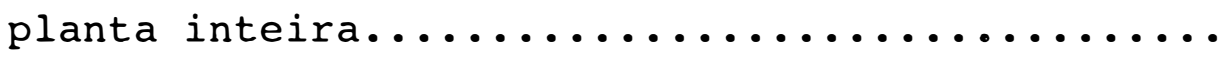

3.8. Teores de conteúdo celular, fibra insolúvel em detergente neutro, fibra insolúvel em detergente ácido, hemicelulose,

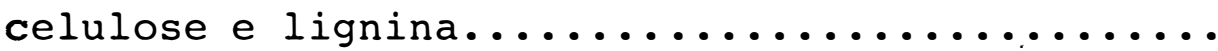

3.9. Digestibilidade "in vitro" da matéria se

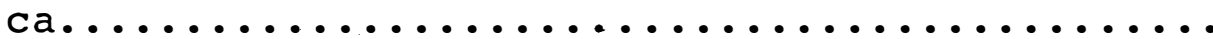

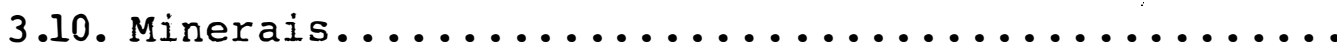

4. RESUltadaos E Discussão.

4.1. Comparação pelo teste Tukey $(P \leq 0,05)$ das médias dos capins e das médias den tro de cada idade de corte................. 
Página

4.1.1. Ganho acumulativo de matéria seca .....

4.1.2. Número de perfilhos por área, peso médio dos perfilhos, relação lâmina:haste, altura da cultura, altu ra do meristema apical e vigor de

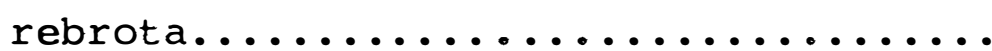

4.1.3. Teor̉es de matéria seca, fibra bruta, proteína bruta e participação porcentual de proteína bruta da lámina e da haste em relação à planta in-

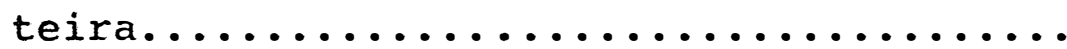

4.i.4. Teores de conteúdo ceìuiar, fibra insolúvel em detergente neutro, fi bra insolúvel em detergente ácido, hemicelulose, celulose, lignina e digestibilidade "in vitro" da matéria seca...................... 50

4.1.5. Teores de minerais................. 56

4.2. Comparação através de equações de regressão dos capins frente as idades de corte estudadas.... 63 4.2.1. Ganho acumulativo de matéria seca dos

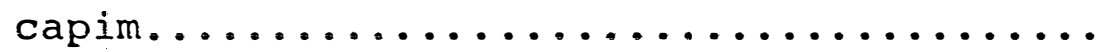

4.2.2. Número de perfilhos por área, peso mé dio dos perfilhos, relação lâmina:has te, altura do meristema apical e vi- 
4.2.3. Teores de matéria seca, fibra bruta e proteína bruta e participação por centual de proteína bruta da lámina e da haste em relação à plánta in-

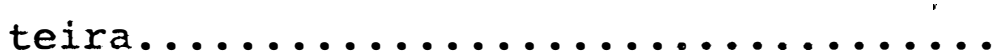

4.2.4. Teores de conteúdo celular, fibra in solúvel em detergente neutro, fibra insolúvel em detergente ácido, hemicelulose, celulose, lignina e digestibilidade "in vitro" da matéria se-

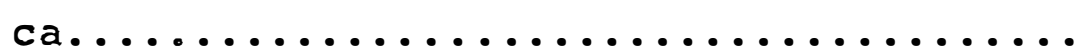

4.2.5. Teores de minerais................. 90

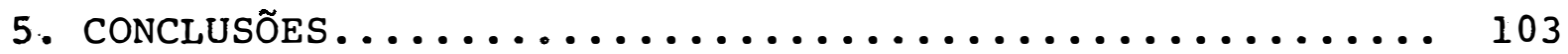

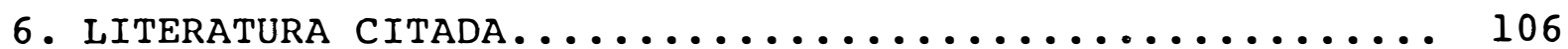

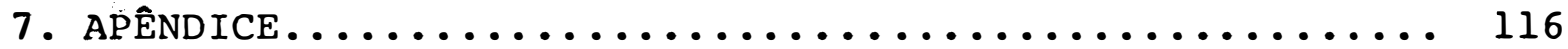


ESTUDO COMPARATIVO DE TRÊS CAPINS DA ESPÉCIE Panicum maximum JACQ. (COLONIÃO, TOBIATÃ E K-187 B)

AUTOR: João Batista de Andrade ORIENTADOR: Dr. José Vicente Silveira Pedreira

RESUMO

Foi desenvolvido no Instituto de Zootecnia, em Nova Odessa, SP, ensaio de ganho acumulativo de matéria seca, para comparar os capins colonião IZ-l, tobiatã e K-187 B . o solo do local foi classificado como Latosol Vermelho Amarelo - fase arenosa. Para a semeadura, realizada em fevereiro de 1983, o terreno recebeu 2 t/ha de calcário dolomítico. As forrageiras foram plantadas em parcelas de 5,00 m x 2,25 m, contendo 20 linhas espaçadas de $0,25 \mathrm{~m}$. A densidade de semeadura foi de 80 sementes viáveis por metro linear. No plantio foram aplicados. $80 \mathrm{~kg} \mathrm{P}{ }_{2} \mathrm{O}_{5} /$ ha (como superfosfato simples) e no corte de uniformização, em setembro de 1983, mais $100 \mathrm{~kg} \mathrm{~N} /$ ha (como sulfato de amônio), $60 \mathrm{~kg} \mathrm{~K} \mathrm{~K}_{2} \mathrm{ha}$ (como cloreto de potássio) e $40 \mathrm{~kg} \mathrm{P}{ }_{2} \mathrm{O}_{5} / \mathrm{ha}$ (como superfosfato simples). O en- 
saio foi instalado em um esquema fatorial 3 x 9 (capins $x$ idades de cortel, com duas repetições. As idades de corte tinham um intervalo de 28 dias e compreendiam um período de vegetação de 252 dias. A produção de matéria seca acumulada de cada capim, em 252 dias de vegetação, atingiu cerca de 18 t/ha, não havendo diferenças entre os capins. Houve efeito significativo de capins em 18 das 33 variáveis estudadas. Os capins colonião IZ-1 e tobiatã apresentaram diferenças significativas em 16 das 33 variáveis estudadas, quais sejam, ganho acumulativo de matéria seca do material verde, número de perfilhos por área, peso médio dos perfilhos, relação lâmina:haste, altura do meristema apical, participação porcentual de proteína bruta de lâmina em relação à planta inteira, participação porcentuaì . de proteína bruta de haste em relação à planta inteira, e relação nitrogènio:enxofre, concentração de enxofre e zinco nas láminas foliares, e porcentagens de matéria seca, fibra bruta , fibra insolúvel em detergente ácido, hemicelulose, celulose e digestibilidade "in vitro" da matéria seca da planta inteira. Entre os capins colonião IZ-l e K-187 B foram verificadas diferenças significativas em 11 das 33 variáveis estudadas: peso médio dos perfilhos, relação lámina:haste, participação porcentual de proteína bruta da lâmina em relação a planta inteira, par ticipação porcentual de proteína bruta de haste em relação à planta inteira, e relação nitrogènio:enxofre, concentração de potássio, enxofre e zinco nas lâminas foliares, e porcentagens de celulose, lignina e digestibilidade "in vitro" da matéria 
seca. Os capins tobiatã e K-187 B apresentaram diferenças significativas em apenas 4 das 33 variáveis estudadas: número de perfilhos por área, e porcentagens de fibra bruta, fibra insolúvel em detergente ácido e celuiose da planta inteira. ofeito significativo de idades de corte foi verificada em 29 das 33 variáveis estudadas. Este efeito só não foi obsèrvado nas variáveis: relação nitrogênio:enxofre e nas concentrações de cálcio, magnésio e manganès da lâmina foliar. Houve interação capins $\mathrm{x}$ idades de corte significativa para: número de perfilhos por área, porcentagens de fibra bruta, fibra insolúvel em detergente ácido, hemicelulose, celulose, lignina e digestibilidade "in vitro" da matéria seca. Estes resultados mostraram que us capins colonião Iz-1, tobiatã e K-187 d aprosentaram padrões de variação distintos frente às idades de corte. Os dados obtidos neste ensaio evidenciaram que os capins tobiatã e K-187 B tiveram comportamentos semelhantes como plantas forrageiras, enquanto o capim colonião IZ-I teve comportamento diferente em relação aos dois primeiros. 
COMPARATIVE STUDY OF THREE GRASSES OF

Panicum maximum Jacq. SPECIES (COLONIÃO, TOBIATÃ E K-l87 B)

AƯTHOR: João Batista de Andrade ADVISER: Dr. José Vicente Silveira Pedreira

SUMMARY

Three grasses of the Panicum maximum species ("Colonião", "tobiatã", and "K-187 B") were studied at the Instituto de Zootecnia, Nova Odessa, State of são Paulo. A plot trial was set on a Red-Yellow Latosol sandy phase. Plots were $5,00 \mathrm{~m} \times 2,25 \mathrm{~m}$ and the grasses were seeded in 20 lines 0,25 m apart in each plot. Eigthy viable seeds were used per linear meter. The experimental area received 2 t/ha of dolomitic limestone and $80 \mathrm{~kg} / \mathrm{ha}$ of $\mathrm{P}_{2} \mathrm{O}_{5}$ (as ordinary superphosphate) at seeding. At the beginning of the experimental period (September 1983 ) $100 \mathrm{~kg} \mathrm{~N} / \mathrm{ha}$ (as ammonium sulfate), $60 \mathrm{~kg} \mathrm{~K}$ O/ha (as potassium chloride), and $40 \mathrm{~kg} \mathrm{P}_{2} \mathrm{O}_{5} / \mathrm{ha}$ (as ordinary superphosphate). A $3 \times 9$ (grasses $\times$ age of harvest) factorial with two replications was the experimental design. Samples were taken 
at 28 days interval, harvesting a new area each time.

The accumulated dry matter yield (total of 252 days) was about $18 \mathrm{t} / \mathrm{ha}$, and three ewere no significant differences among the three grasses. However, significant differences were found among grasses in 18 out of 33 variables studied. Significant differences between "colonião IZ-l" and "tobiatã" were observed in 16 of those variables: accumulative growth measured as dry matter of the live material, number of tillers per area, tiller weight, blade: stem ratio, apical meristem height, crude protein content of blades in relation to whole plant crude protein content, crude protein content of stem in relation to whole plant crude protein content., sulfur and zinc concentrations in the blades, nitrogen: sulfur ratio, and percentages of dry matter, crude fiber, acid detergent fiber, cellulose, hemicellulose and "in vitro" dry matter digestibility in the whole plant. Between "colonião Iz1" and "K-187 B" significant differences were observed in 11 ont of 33 variables: tiller weight, blade: stem ratio, crude protein content of blades in relation to whole plant crude protein content, crude protein content of stem relation to whole plant crude protein content, potassium, sulfur and zinc concentrations in the blades, nitrogen: sulfur ratio, and percentagens of cellulose, lignin and "in vitro" dry matter digestibility in whole plant. "Tobiatã". and "K-I87 B" significantly differed only in 4 out of 33 parameters: number of tillers per area, and crude fiber, acid detergent fiber and 
cellulose percentages in whole plant. For the three grasses the age of harvest was significantly different in 29 out of 33 measured variables: only the concentrations of calcium, magnesium, and manganese, and the nitrogen: sulfur ratio in the blades did not differ. The interaction grasses $x$ age of harvest was significant for: number of tillers per area, and percentages of crude fiber, acid detergent fiber, cellulose , hemicellulose. lignin, and "in vitro" dry matter digestibility in the wholw plant. Grasses showed distinct standards of variation in relation to age of harvest. The results showed that "tobiatã" and "K-187 B" were similar, as forage plants, while colonião IZ-l differed from the others two ones. 


\section{INTRODUÇÃO}

No Estado de São Paulo, o colonião è uma da forrageiras mais utilizadas na engorda de bovinos, em virtude do seu alto potencial de produção de matéria seca, e qualidade de forragem. Todavia, se não são observadas algumas técnicas de manejo, essas pastagens se degradam rapidamente e o coIonião dá lugar para espécies geralmente de hábito prostrado, menos exigentes e mais resistentes ao pisoteio, porém, de menor potencial de produção.

Essa deficiência de manejo, e a conseqüênte degradação da pastagem leva os pecuaristas e os técnicos ligados aosetor à procura de novas espécies ou cultivares que tenham melhor desempenho.

Recentemente foi lançado no comércio o capim tobiatã o qual segundo seus divulgadores, teria um mais alto 
potencial de produção.de matéria seca do que o capim-colonião , bem como sua forragem seria de melhor qualidade, motivos esses que dariam produções animais muito elevadas em termos de Brasil. Embora esse capim ainda seja pouco estudado entre nós, verifica-se pela literatura que a introdução K-187 B, traziāo da Costa do Marfim, Noroeste da África, pela EMBRAPA, o qual deu origem ao tobiațã, foi relativamente bem estudada e utilizada por PERNES et alii (1975), como padrão de comparação dos clones melhorados da espécie (Panicum maximum Jacq.).

Pelos motivos expostos, evidência-se a necessidade de um estudo comparativo entre os capins colonião, tobiatã e K-187 B, avaliando-se os seus potenciais de produção de matéria seca, em diferentes estádios de crescimento, suas alterações morfofisiológicas a cada estádio de crescimento, bem como a qualidade da forragem produzida. 
2. REVISÃO DE LITERATURA

Como regra geral, os ensaios para comparar o potencial de produção de matéria seca e qualidade da forragem, entre espécies ou cultivares de plantas forrageiras, são realizados dentro de um certo manejo (altura de corte, frequêencia de corte, adubação, etc.) definido "a priori". Todavia, se não são conhecidas algumas características morfofisiológicas da planta a ser testada, pode-se subestimar o seu potencial forrageiro, caso o manejo adotado não for adequado. O estudo detalhado do crescimento das plantas forrageiras e o emprego de técnicas de manejo baseadas nas alterações morfofisiológicas poderão levar a aumentos significativos naprodutividade forrageira (LANGER, 1958 e JEWISS, 1966). 


\subsection{Informações sobre os capins estudados}

Conforme relatado em CAPIM CCLONIÃO IZ-1, (1983/84) o capim colonião IZ-l que foi lançado pelo Instituto de Zoctecnia, em $1979 / 80$ através de seleção massal de material proveniente de Guararapes, SF, é descrito como: planta perene de hábito de crescimento cespitoso, com altura média de $4 \mathrm{~m}$; tendo na base em média 6 entre nós curtos e pílosos, fortemente achatados; com folhas quilhadas e acuminadas, de cor azuladas com serosidade brancā, com nervura central bem evidenciada, limbo levemente piloso com bordos serrilhados ; lígula com franja e pelos curtos, colar branco e visível e auriculas pequenas e brancas e paniculas cônicas com $40 \mathrm{~cm}$ de comprimento, espiquetas pareadas uma curta e outra longa pedicelada; semente elíp tica acuminada no ápice, com tegumento amarelo esverdeado, $\operatorname{ccm} 2,8 \mathrm{~mm}$ de comprimento e $1,0 \mathrm{~mm}$ de lar gura, glöbra; tendo de 900 - 1100 sementes por grama.

o capim tobiatã foi lançado como novo cultivar de capim-colonião em janeiro de 1982. (USBERTI FILHO, 1982 e CAPIM COLONIÃO "TOBIATÃ", 1982).

Segundo CAPIM COLONIÃO "TOBIATÃ" (1982) "O cultivar tobiatã, de capim cclonião (Panicum maximum Jacq.) é proveniente da linhagem K-187, introduzida da Costa do Marfim em 1977, através de testes de adaptação e seleção de plantas individuais realizadas em 1978 e 1979. Planta adulta: altura média $200 \mathrm{~cm}$; dimensões de folha: $80 \mathrm{~cm}$ de comprimento e 
4,5 de largura; pilosidade de órgãos: folhas com pouca nenhuma pilosidade; bainhas e lígulas densamente pilosas; perfilhamento: 40 - 45 perfilhos, em média; tamanho de panícula: longa $(65-70 \mathrm{~cm})$, pouco ramificada e frouxa; ciclo de florescimento: 180 dias. Sementes: forma elíp tica, acuminada no ápice, semelhante a do capim colonião comum, medindo de $3-4 \mathrm{~mm}$ de comprimento; sem pilosidade e com nervuras imperceptíveis; tegumento amarelo-esverdeado; número médio de sementes por grama: 720. Produtividade média: 130 - 140 t/ha/ano de massa verde, obtidos em ensaios instalados em Presidente prudente e Araçatuba, em 1981 e 1982, utilizando seis cortes efetuados a cada 45 dias, 8 - 98 de proteína/matéria seca e $65-70 \%$ de digestibilidade "in vitro". Boa palatabilidade e resisténcia ao pisoteio animal; elevado potencial de rebrota após o corte (ou pastoreio)".

Quanto à caracterização morfológica vegetativo e reprodutiva os capins $\mathrm{K}-187 \mathrm{~B}$ e tobiatã poderiam ser descritos* como: Planta de hábito cespitoso, com altura média de aproximadamente $3,5 \mathrm{~m}$, com colmos elípiticos, ocos, globras e com nós pilosos; folhas lineares lanceoladas, lâminas de coloração verde-escura, com aproximadamente $100 \mathrm{~cm}$ de comprimento

* Comunicação pessoal do Eng Agr Bióloga Maria Judith I.R. Gomes do Instituto de Zootecnia: 
e $3,5 \mathrm{~cm}$ de largura, ventral e dorsalmente glabras, com nervura principal ventralmente esbranquiçadas e ventral e dorsalmen te glabra; bainha de ccloração verde-clara, com aproximadamente $27 \mathrm{~cm}$ de comprimento, dorsalmente hirsuto-pilosas; lígula membranácea ccm um denso anel de pêlos longos e grossos por trás; na região ligular a lâmina apresenta pêlos longos e gros sos na região ventral e a bainha apresenta pélos nas margens; inflorescência em pânículas abertas, com pêlos longos e finos, no ponto de inserção dos eixos secundários e das ráquilas; espiguetas com aproximadamente $4 \mathrm{~mm}$, bi-floras, dorsi-ventralmen te comprimidas, de coloração inicialmente verde-arroxeadas e posteriormente havana, la gluma menor, com metade de comprimen to da 2a gluma; 3 - nervada, globra; 20 gluma igual a lema, 5nervada, globra; lema do antécio estaminado membranácea, mútica, 5 - nervada, globra e pálea hialina; lema e pálea do antécio superior fértil cartilaginosas e rugosas, com bordas do lema esverdeado a pálea.

\subsection{Ganho acumulativo de matéria seca}

Trabalhos realizados com plantas forrageiras, a partir de crescimento inicial ou rebrota, demonstraram que o crescimento-padrão (ganho acumulativo de matéria seca), pode ser representado por uma curva sigmóide (BROUGHAM, 1955; BARNES, 1960; PEDREIRA, 1965/66; PEDREIRA e BOIN, 1969 e ANDRADE e GOMIDE, 1971). Todavia, para se observar essa curva sigmóide de crescimento é ncessário que ocorram e sejam avaliadas as fa- 
ses de crescimento vegetativo e reprodutivos. Ensaios nos quais somente a fase vegetativa é avaliada, geralmente tèm os seus padrões de crescimento representados por uma reta (TARDIN et àlii 1971; NASCIMENTO Jr. e PINHEIRO, 1975; GOMIDE e ZAGO, 1980 e BOTREL e GOMIDE, 1981.

Por outro lado, a produção de matéria seca estimada em ensaios de crescimento contínuo deve ser analisada com cuidado, uma vez que as plantas forrageiras, na maioria das vezes são utilizadas para formação de pastagem, onde são pastejadas com uma certa freqüência (PEDREIRA, 1965/66). Contudo, quando são feitas comparações relativas entre cultivares, juntamente com observações morfofisiológicas para os vários estááios ae crescimento, a proaução de matéria seca parece ser um valioso critério auxiliar de seleção, uma vez que pode sugerir o manejo mais adequado.

PEDREIRA (1965/66) verificou produções de matéria seca de 6.621 a $21.775 \mathrm{~kg} / \mathrm{ha}$ para o colonião aos $50 \mathrm{e}$ 173 dias de crescimento. GOMIDE et alii (1979 a) registraram produções de matéria seca de $83 \mathrm{~kg} / \mathrm{ha} /$ dia para o colonião. GoMIDE e ZAGO (1980), para o colonião na fase vegetativa, aos 63 dias de crescimento, obtiveram produções de 27,3 a 75,8 kg/ha/ dia e PEDREIRA (1973), estudando a estacionalidade de produção de vários capins, obteve para o capim-colonião (média de 5 anos) $10.115 \mathrm{~kg} / \mathrm{ha}$ de MS, com produções diárias de 64,0 e 2,0 de MS $\mathrm{kg} / \mathrm{ha} / \mathrm{dia}$, respectivamente para máxima de verão e mínima de inverno. BOYER (1977), em experimento no Senegal com o cultivar 
K-187 B de Panicum maximum Jacq. e com outras 6 gramineas tropicais, estudou o consumo de água e a produção de matéria seca, obtendo cerca de $43.000 \mathrm{~kg} / \mathrm{ha} /$ ano com produções diárias que variaram de 83,5 a $192,0 \mathrm{~kg} / \mathrm{ha}$. Ressalta-se que essas produções foram conseguidas no senegal, onde a disponibilidade dos fatores climáticos de crescimento é alta e com aplicações de $600 \mathrm{~kg}$ de $\mathrm{N}, 600 \mathrm{~kg}$ de $\mathrm{K}$ e $200 \mathrm{~kg}$ de $\mathrm{P}$ por ha, parceladas 4 ve zes por ano.

PERNES et alii (1975) conduziram ensaios para a intensificação da produção forrageira em Costa do Marfim com clones de Panicum maximum, verificando que o tetraplóide $\mathrm{K}-187$ B foi dos mais produtivos.

2.3. Número de perfilhos por área, peso médio dos perfilhòs, relação lâmina:haste, altura da cultura, altura do meristema apical e vigor de rebrota

O alto potencial de repodução de capins tropicáis e a cápacidade de perfilhar, conferem a tais plantas excelentes atributos forrageiros.

O número de perfilhos por área depende da capacidade de perfilhamento da espécie, da estação do ano e do manejo adotado.

Segundo JEWISS (1972), a alta capacidade de perfilhamento dos capins auxilia o estabelecimento e assegura a perenidade da pastagem. CORSI (1972) afirma que o perfilha- 
mento pode aumentar a produção de matéria seca e determinar o espaçamento de certas culturas; de acordo com CosTA (1982), o perfilhamento resulta numa cobertura maior do terreno, evitando assim, a erosão e o estabelecimento de plantas invasoras.

LEOPOLD (1949) sugere que o perfilhamento está sob ccntrole hormonal regido pela dominância apical. Todavia, em planta originária de semente parece qué nos primeiros estádios de crescimento essa dominância apical é fraca, pois, sesundo TROUGHTON (1955), em capins de clima temperado o perfilhamento em plantas jovens é exponencial e persiste até ao redor dos 70 dias após a germinação, quando então cessa. LANGER (1963) também afirma que a formação de perfilhos é exponencial, desde que não haja fatores limitantes, uma vez que o perfilhamento é afetado por fatores ambientais e genéticos. Pa ra SINGH e CHARTERJEE (1966), os fatores de crescimento, luz, temperatura e umidade do solo, são essenciais para o perfilhamento, porém, com a ccntínua disponibilidade desses fatores ocorre o alongamento e desenvolvimento dos perfilhos, reduzindo, mais tarde, a atividade de perfilhamento. 0 perfilhamento de gramíneas forrageiras trcpicais parece, segundo PEDREIRA (1975), obedecer a uma estacionalidade. Este autor verificcu para o colonião em crescimerto livre, que havia duas épocas de baixo perfilhamento, ou seja, 2/3 finais do verão e em fins do outono. Sugere que a queda de verão talvez fosse de vida ao grande sombreamento oferecido pelo intenso perfilhamento e crescimento vegetativo que ocorre na primavera e no 
início de verão. Essa hipótese de sombreamento reduzindo o perfilhamento, também foi sugerida por CORSI (1972) e JEWISS (1972).

Para o capim colónião, segundo PEDREIRA (1965/ 66) e GOMIDE et alii (1979 b), o aparecimento das primeiras gemas basilares ocorre por volta dos 50 dias de brotação do - perfilho.

NASCIMENTO et alii (1980), estudando os capins colonião, jaraguá e gcrdura, verificaram que o capim colonião foi o que menos perfjlhou, apresentando, no entanto, o maior número de gemas basilares por perfilho.

Estudos de crescimento contínuo de capins têm revelado que o niimorn de perfilhos cai com $\propto$ avango na idade da planta; essa queda seria devida à competição dos perfilhos pelos fatores de crescimento, e quanto maior o peso seco por perfilho menor o númєıro destes por área, no final do ciclo da forrageira.

PEDREIRA (1965/66) registrou para o capim colonião, em crescimento contínuo, 312; 243; 109; 93; 83; 111 e 68 perfilhos, respectivamente para as idades de 26 ; 50 ; 68; 89 ; 110; 132 e 152 dias de crescimento, para uma área de 0,20 $\mathrm{m}^{2}$. Essa queda no número de perfilhos com a idade é ainda mais acentuada para o capim-elefante napier (PEDREIRA e BOIN, 1969). o peso médio de perfilhos, aumenta com a idade da planta. De acordo com PEDREIRA (1965/66), em ensaios de crescimento contínuo, os maiores rendimentos de matéria seca 
não estavam relacionados positivamente com o número de perfilhos e sim com peso individual de perfilho. Esses resultados foram comprovados por PEDREIRA e BOIN (1969), para o capim elefante napier. Todavia, PEDREIRA (1965) cita knight (1961) que ressalta que sob cortes ou pastejo freqüèntes o perfilhamento rápido poderia ser importante, embora houvesse pequena relação entre a produção de matéria seca de Dactylis glomerata em crescimento contínuo e a capacidade de perfilhamento. Segundo MECELIS (1979) para o colonião cortado sob várias freqüências verificou-se uma relação negativa entre a produção de matéria seca e o número de perfilhos. FERRARIS e SINCLAIR (1980 a e b) verificaram que para o capim elefante os rendimentos de rebrota eram lineares e positivamente correlacionados com a densida de de perfilhos. Contudo, PEDREIRA (1973) em trabalho sobre a estacionalidade da produção de matéria seca do capim colonião, verificou que o número de perfilhos no verão não era estatistí camente diferente do número de perfilhos no inverno; todavia, o peso individual dos perfilhos no verão era superior ao peso dos perfilhos no inverno. Essa situação levou o autor a sugerir que para o capim colonião a produtividade estava relacionada comopeso individual de perfilhos e não com 0 seu número.

A relação lâmina:haste nos capins está diretamente relacionada com o valor nutritivo dos mesmos. Para WHITE MAN (1980) a qualidade de uma forragem depende basicamente de dois componentes quais sejam, a dua digestibilidade e seu consumo voluntário. Desta maneira, um mais baixo potencial de 
produção de matéria seca pode ser compensado por um melhor valor nutritivo da forragem.

É sabido que para estádios avançados de crescimento as partes das plantas tèm maiores diferenças entre si quanto à digestibilidade (GOMIDE, 1973 e HACKER e MINSON, 1981). Todavia, segundo MINSON (1980), mesmo para digestibilidades iguais, o consumo voluntário da fração lâmina é até $44 \%$ mais alto do que o da fração haste. Este fato sugere que forrageiras que tenham diferentes relações lâmina:haste, também teriam diferentes consumos voluntários. MINSON (1971), estudando a digestibilidade e o consumo de 6 variedades de Panicum maximum, verificou que relações lâmina:haste de 0,67, 0,80 e 1,00 foram suficientes para anresentarem consumos voluntárins diferentes entre si. Nesse trabalho, as maiores porcentagens de lámina apresentadas foram dos capins colonião e hamil, os quais também foram os mais consumidos. Por essas razões, a relação lâmina:haste parece ser um bom critério auxiliar de seleção de cultivares de Panicum.

PEDREIRA $(1965 / 66)$ registrou para o capim colonião em crescimento contínuo nas idades de 26 ; 50 ; 68 ; 89 ; 110, 132 e 152 dias, as relações Iămina:haste de 0,95; 1,30 ; 1,$25 ; 0,95 ; 0,81 ; 0,68$ e 0,57 , respectivamente.

A relação lâmina:haste é inversamente relacionada à altura da planta (PRINE e BURTON, 1956). Esta afirmativa concorda com os resultados de PEDREIRA (1965/66) para o capim colonião e com os de PEDREIRA e BOIN (1969) para o ca- 
pim elefante napier.

A altura da cultura é um importante fator de manejo de pastagem, uma vez que a entrada e a retirada dos animais da mesma é usualmente condicionada à altura de sua vegetação.

A posição do meristema apical está diretamente relacionada com a decapitação de perfilhos, o que segundo BOOYSEN et alii (1963), GOMIDE et alii (1979 b), GOMIDE e ZAGO (1980) e BOTREL e GOMIDE (1981), é o fator mais limitante na determinação do vigor de rebrota.

A "altura" do meristema apical é geralmente me dida como sendo a distāncia entre a gema apical e a base do colmo. Cómo mediua relativa na comparação de cultivarcs ou cspécies esse parâmetro é válido. Porém, para o cálculo da porcentagem de perfilhos decapitados, é provável que ocorra algum tipo de erro, pois, para alguns capirs, como é o caso do colonião, os perfilhos tèm geralmente uma posição oblíqua, o que leva a uma efetiva redução da altura do meristema apical em relação à superfície do solo.

Entre outros fatores a elevação do meristema apical varia com a espécie, adubação e altura de corte (GOMIDE et alii, 1979 b e NASCIMENTO et alii (1980)

Para o capim colonião nas idades de 14,$28 ;$ 42; 56; 70, 84 e 98 dias, GOMIDE et alii (1979 b) verificaram respectivamente às alturas de 0,$6 ; 0,8 ; 4,4 ; 15,2 ; 36,0,60,0$ e 77,0 cm do ápice meristemático. NASCIMENTO et alii (1980), 
em estudo com os capins jaraguá, colonião e gordura, observaram alturas de 1,$0 ; 1,8 ; 2,3 ; 11,7 ; 22,7$ e $32,7 \mathrm{~cm}$ do ápice meristemático para o colonião às idades de $21 ; 28 ; 35 ; 49 ; 63$ e 77 dias de crescimento, respectivamente.

o vigor de rebrota, medido em $\mathrm{kg} / \mathrm{ha}$ de matéria seca, é altamente relacionada com a decaṕtação de perfilhos.

GOMIDE et alii (1979 b) encontraram para rebrotas de parcelas de diversas idades de capim colonião, produções que variaram de 1.659 a $333 \mathrm{~kg} / \mathrm{ha}$ de matéria seca, sendo que as maiores produções eram rebrotas de parcelas cujo corte inicial não resultavam em elevada decapitação de perfilhos. Em com parações da mesma ordem, GOMIDE e ZAGO (1980) também verifica-

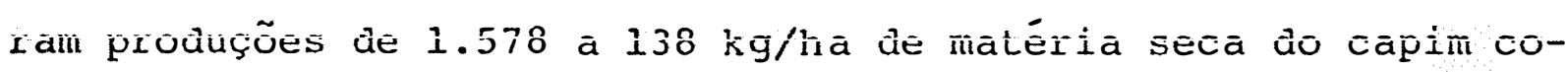
lonião, sempre em alta relação negativa com a decapitação de perfilhos.

2.4. Teores de matéria seca, fibra bruta, proteína bruta e participação porcentual de proteína bruta contida na. lâmina e na haste em relação à proteina bruta da planta inteira

O teor de matéria seca das plantas forrageiras aumenta com a maturação da planta.

PEDREIRA (1965/66) verificou para o colonião cortado aos $26 ; 50 ; 68 ; 89 ; 110,132$ e 152 dias de crescimento, 17,$8 ; 16,4 ; 17,0 ; 21,4 ; 22,0 ; 26,1$ e $26,3 \%$ de matéria seca, res 
pectivamente.

Deve-se ressaltar, conforme os resultados de GOMIDE et alii (1969 a), que o teor de matéria seca varia com a espécie forrageira, a idade da planta e o ano.

A variação do teor. de fibra bruta com a idade da planta é conhecida há muito tempo.

PEDREIRA e SILVEIRA (1972) obtiveram para

○ capim colonião cortado aos 26; 50; 68; 89; 110; 132 e 152 dias de crescimento, 19,$4 ; 35,8 ; 40,7 ; 42,7 ; 42,7 ; 43,8$ e $42,8 \%$ de fibra bruta, respectivamente. Nota-se, por esses resultados , que o maior aumento no teor de fibra bruta ocorreu entre as idades de 26 e 50 dias.

¿̀ semelhança da variação no teor de fibra bruta, a variação no teor de proteína bruta com a maturação da planta também é conhecida há muito tempo. Todavia, na maior parte dos trabalhos sobre composição bromatológica de plantas forrageiras essa fração só é determinada nas amostras de planta inteira, podendo não representar satisfatoriamente a dieta de animais a pasto, devido a seletividade exercida pelos mesmos às partes da planta.

PEDREIRA e SILVEIRA (1972) registraram para o colonião cortado aos 50; 68; 89; 110; 132 e 152 dias, respectivamente os teores de 19,$8 ; 14,4 ; 14,6 ; 12,9 ; 11,9$ e $11,3 \%$ de proteína bruta na lâmina foliar, 16,$7 ; 12,6 ; 12,6 ; 8,6 ; 6,3$ e $5,9 \%$ de proteina bruta na haste e 17,$7 ; 12,6 ; 12,6 ; 11,1 ; 8,9$ e 7,7\% de proteína bruta na planta inteira, todos na base de 
matéria seca. Verifica-se, por esses resultados, que a queda nos teores de proteína bruta da haste é muito mais acentuada do que da lâmina foliar em idades mais avançadas, tornando-se evidente a importância da relação lâmina:haste na qualidade da forragem, visto que a fração lâmina tem o consumo e a digestibilidade menos afetados com a maturação da planta.

GOMIDE et alii (1979 a) verificaram para plan ta inteira do capim colonião cortado aos $28 ; 42 ; 56 ; 70 ; 84$ e 98 dias os teores de 21,$2 ; 16,8 ; 13,6 ; 9,4 ; 9,0$ e $7,7 \%$ de proteína bruta, respectivamente.

A participação porcentual de proteína bruta de lâmina e de haste em relação à planta inteira é parâmetro que pođe auxiliar na avảiáçãó relativã de espáciss ou cultivares forrageiros.

2.5. Teores de conteúdo celular, fibra insolúvel em detergente neutro, fibra insolúvel em detergente ácido, hemicelulose, celulose, lignina e digestibilidade "in vitro." da matéria seca

O conteúdo celular tem digestibilidade de $100 \%$; contudo, o seu teor nas gramíneas forrageiras tropicais é baixo.

Por outro lado, a digestibilidade da fração fibra insolúvel em detergente neutro é afetada pelo arranjamento da hemicelulose e celulose na parede celular e do grau de lignificação (VAN SOEST, 1967). 
Segundo VAN SOEST (1965), teores de fibra insolúvel em detergente neutro acima de $60 \%$ causam limitação no consumo da forragem. Isto tem conseqüências na nutrição de bovinos, pois, segundo FLORIO (1976), que estudou a composição da fibra em gramineas forrageiras tropicais (planta inteira) , os teores de fibra em detergente neutro estavam sempre acima de $65 \%$, ocorrendo com mais freqüència teores de 70 a $80 \%$.

Segundo THOMAS (1982), em capins tropicais a variação nos teores de fibra insolúvel em detergente neutro tem sido 56 a $80 \%$ na matéria seca.

FLORIO (1976) verificou que os capins tropicais não apresentam diferenças marcantes quanto aos componentes da narede celular (fibra insolúvel em detergente neutro).

A fração fibra em detergente ácido contém prin cipalmente celulose e lignina. Esta fração é a portadora da maior quantidade de energia das plantas forrageiras, contudo, sua digestibilidade também é afetada como a da parede celular.

A variação dos teores de fibra insolúvel em detergente ácido nas gramíneas forrageiras tropicais, segundo THOMAS (1982), é de 32 a $46 \%$ na matéria seca.

ANDRADE (1973) obteve para o capim colonião em crescimento contínuo, cortado aos 35; 55; 85; 115 e 145 dias, os teores de 36,$3 ; 31,8 ; 26,6 ; 23,3$ e $20,2 \%$ de conteúdo celular, de 63,$7 ; 68,2 ; 73,4 ; 76,6$ e 79,7\%. de fibra insolúvel em detergente neutro e de 34,$0 ; 40,0 ; 47,5 ; 53,1$ e $56,9 \%$ de fibra insolúvel em detergente ácido, respectivamente. Por esses 
resultados, nota-se que mesmo em estádios iniciais de crescimento (35 dias) o colonião teria o teor de fibra insolúvel em detergente neutro limitando o consumo.

Segundo ANDRADE (1973), o qual cita vários autores, há controvérsias sobre qual dos componentes da parede celular (hemicelulose ou celulose) que tem maior digestibilida de, todavia, ambas as frações tem uma porção indigestível.

Dentre os componentes da fibra insolúvel em detergente neutro a hemicelulose é aquele que menos varia com a maturação da planta, tendo os maiores teores nas plantas mais jovens.

Em capins tropicais, a celulose, segundo FLORIO (1976), foi o único componente da parede celular gue teve seus teores aumentados significativamente com a adubação.

A lignina das plantas forrageiras é totalmente indigestível. Segundo THOMAS (1982), sua variação nos capins tropicais é de 3 a $8 \%$ na matéria seca.

ANDRADE (1973) verificou para o colonião em crescimento contínuo, cortado aos 35; 55; 85; 115 e 145 dias, os teores de 29,$7 ; 28,2 ; 25,9 ; 23,5$ e 22,8\% de hemicelulose, 17,$6 ; 32,2 ; 37,6 ; 40,5$ e $43,2 \%$ de celulose e de 3,$8 ; 5,7 ; 7,4 ;$ 10,0 e 11,2 de lignina, na matéria seca, respectivamente.

Segundo GOMIDE et alii (1979 a) a digestibilidade das plantas forrageiras cai com a. sua maturação. Para o colonião em crescimento contínuo, cortado aos $28 ; 42 ; 56 ; 70$ e 84 dias, os autores obtiveram 73,$0 ; 68,5 ; 61,8 ; 55,6$ e $52,6 \%$ 
de digestibilidade "in vitro" da matéria seca. Levando em conta os teores de proteína bruta, de minerais e a digestibilidade "in vitro" da matéria seca, concluíram que o fator que mais afetou o valor nutritivo da forragem foi a sua idade.

\subsection{Teores de minerais}

Os minerais mais comumente analisados nas forragens são o cálcio e o fósforo. Todavia, outros minerais são importantes para o desempenho animal. WHITEMAN (1980) cita Minson et alii (1967), os quais sugerem os seguintes teores de elementos minerais na dieta de gado de corte: fósforo, 0,22\% ; notássio, 0.31 a $0.44 \%$ : cálcio, 0,22 a $0.35 \%$; magnésio, 0,12\%; ferro, 30 ppm; manganès, 40 ppm;.zinco, 20 a 40 ppm; e cobre, 4 a 10 ppm, todos com base na matéria seca. Para o enxofre, NATIONAL RESEARCH COUNCIL (1984) sugere 0,1\% na matéria seca como sendo a exigência do elemento para o gado de corte. Todavia, segundo GALLO et alii (1974), quando se avaliam minerais na forragem, para relacionar os seus níveis na planta com as exigências animais, devem ser consideradas algumas limitações, tais como variações com a época do ano, pastejo seletivo, variação do consumo animal e disponibilidade para os animais. GALLO et alii (1974) verificaram que os elementos, sódio, zinco, enxofre, fósforo, cobalto, cobre, nitrogênio e cloro contidos em capins eram os que apresentavam teores abaixo das necessidades admitidas para o gado de corte. 
GOMIDE et alii (1969 b) em estudo com 6 gramíneas tropicais, verificaram que os teores de fósforo decresceram com a idade da planta, variando de 0,26 a $0,12 \%$ na matéria seca das plantas cortadas aos 28 e 252 dias, respectivamente. Observaram ainda que havia diferenças entre as espécies estudadas. PEDREIRA e SILVEIRA (1972), estudando a composição bromatológica do capim colonião em crescimento contínuo, obser varam na planta inteira cortada aos $26 ; 50 ; 68 ; 89 ; 110 ; 132$ e 152 dias, os seguintes teores de fósforo na matéria seca: 0,28; 0,$23 ; 0,15 ; 0,12 ; 0,11 ; 0,09$ e 0,10, respectivamente. GOMIDE et alii (1979 a), obtiveram para o capim colonião cortado aos 28; 47; 56; 70 e 84 dias, os respectivos teores de fósforo de 0,$18 ; 0,13 ; 0,14 ; 0,12$ e 0,04\% na matéria seca da planta inteira. Todavia, para avaliação de minerais a nivel de pastágem, recomenda-se a amostragem somente de lâmina foliar, devido a seletividade dos bovinos durante o pastejo. PEDREIRA e SILVEIRA (1972), avaliando o teor de fósforo na lâmina de capim colonião, verificaram que nesta fração da planta os teores se mantinham mais elevados e por um maior intervalo de tempo do que aqueles verificados na planta inteira e haste. Para as lâminas colhidas nas idades de 50; 68; 89; 110; 132 e 152 dias, os autores obtiveram os seguintes teores de fósforo na matéria seca: 0,$23 ; 0,12 ; 0,15 ; 0,15 ; 0,12$ e 0,11, respectivamente. Se for considerado o teor de fósforo sugerido por Minson et alii (1967), citados por WHITEMAN (1980), verifica-se que o capim colonião somente atenderia as exigéncias 
de fósforo se fosse pastejado até a idade de 50 dias.

Com relação ao cálcio na planta forrageira , GOMIDE et alii (1969 b) verificaram que os teores do elemento variam com a espécie e com o ano: GOMIDE et alii (1979 a) encontraram para o colonião cortado áos $28 ; 42 ; 56 ; 70$ e 84 dias os seguintes teores de cálcio na matéria seca: 0,48; 0,49; 0,$36 ; 0,33$ e $0,32 \%$, respectivamente.

Nas lâminas do capim colonião, PEDREIRA e SILVEIRA (1972), obtiveram aos 50; 68; 89; 110; 132 e 152 dias de crescimento, os teores de 0,$54 ; 0,47 ; 0,57 ; 0,62$ e $0,58 \%$ de cálcio na matéria seca, respectivamente.

Para o magnésio, os resultados de GOMIDE et alii (1969 b) demnnctraram gie $n$ tonr th olomento é afetado pela espécie forrageira, pela idade da planta e pelo ano, havendo ainda interações entre espécies $\mathrm{x}$ idade e ano $\mathrm{x}$ espécie x idade. Os teores encontrados por GOMIDE et alii (1979 a) para a planta inteira de capim colonião cortado aos 28; 42; 56 ; 70 e 84 dias foram: 0,$26 ; 0,28 ; 0,24 ; 0,21$ e 0,18\% na matéria seca, respectivamente. Estes teores são bastante inferiores aos encontrados por GOMIDE et alii (1969 b) para o capim sempre verde, cortado aos 28; $84 ; 140 ; 196$ e 252 dias de crescimento, que foram: 0,$41 ; 0,45 ; 0,46 ; 0,50$ e $0,46 \%$ na matéria seca, res pectivamente.

Em trabalho de GOMIDE et alii (1969 b), os teores de potássio nas plantas forrageiras variaram com a idade das mesmas; nesse mesmo trabalho näo se verificou diferenças 
entre espécies de capins. GOMIDE et alii (1979 a) obtiveram para o colonião cortado aos $28 ; 42 ; 56 ; 70$ e 84 dias os seguintes teores de potássio na matéria seca da planta inteira: 2,28 ; 2,$03 ; 2,22 ; 2,51$ e $2,38 \%$ respectivamente.

Com relação ao enxofre na forragem, sabe-se que além dos seus níveis, é importante a sua relação com os teores de nitrogênio. PLAYNe (1969), KENNEDY e SIEBERT (1972), REES et alii (1974) e REES e MINSON (1976) estudaram o enxofre como nutriente para animais e fertilizante para as plantas forrageiras, e as variações deste elemento com o nitrogênio, afetando o consumo, a digestibilidade e a retenção de nitrogênio pelo animal. Verificaram que a forrageira fertilizada com enxofre, passando o teor do elemento de um nível de 0,09\% para 0,15\% na matéria seca, tinha o seu consumo aumentado em até $48 \%$. Sabé-se que relação $\mathrm{N}: \mathrm{S}$ mais adequada para nutrição animal é em torno de 14. Todavia, desde que o teor de enxofre na matéria seca esteja acima de $0,10 \%$, relações superiores a 14 não trariam nenhuma conseqüência desastrosa para o animal.

Os minerais cobre, ferro, manganès e zinco, são requeridos em menores quantidades pelos animais.

Para GOMIDE et alii (1969 b) as espécies forrageiras variam em relação aos seus teores de cobre, não tendo sido possível verificar tendência definida quanto à variação desse animal com a idade da planta. Para o colonião, GOMIDE et alii (1979 a) verificaram teores que variaram de 10 a 15 ppm na matéria seca. Em um dos experimentos do trabalho de GOMIDE et 
alii (1979 a) foi constatado o efeito da idade da planta obtendo os autores os seguintes teores de cobre na matéria seca: 19; 18 ; 17 e 17 ppm, respectivamente para o colonião cortado aos 21 ; $35 ; 49$ e 73 dias. Os teores de ferro no trabalho de GOMIDE et alii (1969 b) foram afetados pelas espécies forrageiras pela idade da planta. Os autores encontraram para o capim sempre verde cortado na 4a ; 12a ; 20a ; 28a e 36ạ semanas, os respectivos teores de fer ro de 725; 353; 484; 261 e 195 ppm na matéria seca. Esses tẹres encontrados estavam muito acima dos requeridos pelos animais.

Quanto aos teores de manganês, embora GOMIDE et alii (1969 b) não tenham encontrado diferença significativa entre espécies, apontam que o teor obtido para o capim pangola (248 ppm) era bastante superior ao encontrado para o bermuda (64 ppm). Ressaltaram também que a adubação aumentou em 41 ppm o teor de manganês em todas as forrageiras. Para o capim coloniãc, GOMIDE et alii (1979 a) encontraram teores mangañes de 199; 246; 241 e 238 ppm nas idades de 21; 35; 46 e 63 dias de crescimento, respectivamente.

Os teores de zincc na forragem no trabalho de GO MIDE et alii (1969 b) não foram afetados nem pela espécie, nem pela fertilização com nitrogènio.

Os teores de zinco no trabalho de GOMIDE et alii (1979 a) variaram com a idade da plantạ. Para as idades de 21; 35; 44 e 63 dias, os teores obtidos foram de 22; 18; 17 e 16 ppm na matéria seca, respectivamente. 
3. MATERIAL E MÉtOdOS

O experimento foi instalado em área da Estação Experimental Central do Instituto de Zootecnia, em Nova Odessa, SP, localizada nas coordenadas geográficas de $22^{\circ} 42$ ' latitude Sul, $47^{\circ} 18^{\prime}$ longitude Oeste, a 550 metros de altitude. Para a instalação do experimento as sementes do capim tobiatã foram conseguidas no Instituto Agronómico do Estado de São Paulo, em Campinas, SP; as da introdução K-187 B vieram do Centro Nacional de Pesquisa de Gado de Corte da EMBRAPA, Campo Grande, MS, e as sementes de capim colonião IZ1 foram produzidas no campo de sementes básicas do Instituto de Zootecnia do Estado de São Paulo, em Nova Odessa, SP.

A Tabela 1 mostra a qualidade das sementes dos très capins, bem como a quantidade. calculada para garantir 80 
sementes viáveis por metro linear.

Tabela 1. Qualidade das sementes dos 3 capins estudados e quantidade usada para garantir 80 sementes viáveis por metro linear

\begin{tabular}{lcccc}
\hline CAPINS & $\%$ G $28 \mathrm{D}^{(1)}$ & $\% \mathrm{p}^{(2)}$ & No $\mathrm{s} / \mathrm{g}^{(3)}$ & $\mathrm{g} / \mathrm{m}^{(4)}$ \\
\hline K-187 B & 82 & 15,5 & 767 & 0,820 \\
Colonião IZ-1 & 42 & 76,0 & 988 & 0,254 \\
Tobiatã & 73 & 90,0 & 558 & 0,220 \\
\hline
\end{tabular}

(1) - Porcentagem de germinação aos 28 dias; (2) - porcentagem de pureza; (3) - número de se mentes viáveis por grama; (4) - gramas de sementes por metro linear.

o solo da área experimental é classificado cọ mo Latossol Vermelho Amarelo-fase arenosa, apresentando a seguinte análise química, anterior ao plantio: 2,7 a 3,0 \% de matéria orgânica; $\mathrm{pH} 4,7 ; 0,9$ a 1,1 de $\mathrm{Al}^{3+} ; 0,4$ a 0,8 de $\mathrm{Ca}^{2+}$; 0,2 a 0,3 de $\mathrm{Mg}^{2+}$ todos em e.mg/100 $\mathrm{ml}$ de TFSA; 56 a 68 de $\mathrm{K}^{+}$ e 4.1 de $\mathrm{P}$ ambos em Mg de TFSA.

Foram aplicados $2.000 \mathrm{~kg} / \mathrm{ha}$ de calcário dolomítico, incorporados três meses antes do plantio.

Durante a realização da fase de campo (setembro de 83 a maio de 84 ) foram observadas as médias de temperaturas e precipitações pluviais constantes na Tabela 2 . 
Tabela 2. Média mensal de precipitação pluvial (1968 - 1980) e total mensál de precipitação pluvial $(\mathrm{mm})$ e médias mensais das temperaturas mínima e máxima $\left(C^{0}\right)$ obtidas no Pos to metereológico do Instituto de Zootecnia

Set. Out. Nov. Dez. Jan. Fev. Mar. Abr. Maio

\begin{tabular}{lrrrrrrrrrr}
\hline Temp. mínima & 14,7 & 17,0 & 17,4 & 19,2 & 19,9 & 20,7 & 19,0 & 17,1 & 14,6 \\
Temp. máxima & 23,9 & 28,1 & 29,9 & 28,9 & 31,9 & 34,6 & 31,6 & 28,1 & 28,5 \\
Precipitação & 242,4 & 125,0 & 82,8 & 226,0 & 170,7 & 13,8 & 58,3 & 82,1 & 101,0 \\
Precip. média $(1968-1980)$ & 67,5 & 119,5 & 144,6 & 179,2 & 207,7 & 162,9 & 110,1 & 78,9 & 52,2 \\
\hline
\end{tabular}

A semeadura foi realizada manualmente de 4 a 7 de fevereiro de 1983. Para isso, as sementes foram misturadas à uma porção de superfosfato simples correspondente a uma aplicação de $400 \mathrm{~kg} / \mathrm{ha}$. A mistura de sementes mais adubo foi diluído a $50 \%$ com areia grossa lavada. As quantidades de sementes, adubo e areia, previamente pesadas, foram misturadas no momento da semeadura no campo. Após a semeadura as sementes foram cobertas por uma fina camada de terra, recebendo, em seguida, compactação uniforme por meio de uma roda de ferro de $15 \mathrm{~kg}$ aproximadamente.

Antes do periodo experimental propriamente dito, foi efetuado, em 13 de julho de 1983, um corte de rebaixamento. Em 20 de setembro de 1983, para início da fase de coleta de dados, foi realizado um corte de uniformização a $10 \mathrm{~cm}$ da superfície do solo. Nesse dia, após o corte e retirada do material, foi efetuada uma adubação correspondente a $100 \mathrm{~kg} \mathrm{~N} / \mathrm{ha}$ (como sulfato de amōnio), $40 \mathrm{~kg} \mathrm{P}{ }_{2} \mathrm{O}_{5} / \mathrm{ha}$ (como su- 
perfosfato simples) e $60 \mathrm{~kg} \mathrm{~K}_{2} \mathrm{O} / \mathrm{ha}$ (como cloreto de potássio). Foram plantados 2 blocos com 9 parcelas (idade de corte) de cada capim. Todas as parcelas dentro de cada bloco foram totalmente casualizadas.

A parcela experimental media 5,00 a $2,25 \mathrm{~m}$, contendo 20 linhas de plantio distanciadas $0,25 \mathrm{~m}$ uma da outra.

As análises de variância obedeceram um esquema fatorial de $3 \times 9$ (capins $\times$ idade de corte). A Tabela 3 mostra o esquema geral para análise de variância.

Tabela 3. Esquema geral para análise de variância

FONTES DE VARIAÇÃO

GRAU DE LIBERDADE

\begin{tabular}{lr}
\hline Blocos & 1 \\
Capins & 2 \\
Idade de Corte & 8 \\
Capin x idade de corte & 16 \\
Resíduo & 26 \\
Total & 53
\end{tabular}

Os esquemas da análise de variāncia para outras variáveis, que foram avaliadas com menor número de idades de corte, foram adaptados para cada caso.

As médias dos tratamentos foram comparados através do teste Tukey a $5 \%$ de probabilidade.

Para estudar o comportamento dos capins nas idades de corte foram estimadas as esquações de regressão das variáveis. 
$\mathrm{Na}$ comparação entre os capins as seguintes variáveis foram estudadas:

3.1. Crescimento em ganho acumulativo de matéria seca da parte aérea

A avaliação da matéria seca produzida foi realizada através de 9 idades de corte espaçádas dentro de um período de crescimento de 252 dias, entre os meses de setembro de 1983 a maio de 1984. Os cortes foram feitos a cada 28 dias, de modo que as idades de corte foram: 28 ; 56 ; 84 ; 112 ; $140 ; 168$; $196 ; 224$ e 252 dias.

No transcorrer do experimento, devido a um período de baixa pluviosidade durante o mês de fevereiro de 1984, verificou-se que os capins haviam secado bastante. Na avaliação da produção de matéria seca dicidiu-se então separar o material colhido em duas frações, ou seja, material verde e material seco. Esse procedimento permitiu a partir da idade de 168 dias avaliar a matéria seca produzida como três variáveis : a primeira como matéria seca total. correspondente à soma do material verde e do material seco colhido na parcela (MST) ; a segunda como matéria seca do material verde (MSV); e a terceira, como matéria seca correspondente ao material colhido (MSS).

Para avaliação da matéria seca produzida

$(\mathrm{kg} /$ ha), foram cortadas dentro das parcelas experimentais áreas de $1,50 \mathrm{~m}^{2}$ tendo como bordadura uma faixa de 0,75 $\mathrm{m}$ de largura 
em todo o perímetro.

O corte das forrageiras era efetuado a $10 \mathrm{~cm}$ da superfície do solo. Toda a forragem cortada na área de 1,50 $m^{2}$ foi ensacada e transportada para o laboratório, onde foi pesada e amostrada. Até a idade de 140 dias foi retirada somente uma amostra por parcela, pois até aquele momento a ocorrência de material seco na amostra era pequena. A partir da idade de 168 dias o material colhido foi separado e pesado nas frações verde e seca, retirando-se uma amostra de cada. amostras das forrageiras, foram picadas, pesadas e deixadas em estufa secadora de ventilação forçada a $65^{\circ} \mathrm{C}$ até peso constante, o que foi atingido em 72 horas aproximadamente. Depois da secagem as amostras eram pesadas, após equilíbrio com o ambien te e moídas passando em peneira de 40 "mesh". As amostras moídas eram acondicionadas em saquinhos de polietileno e enviadas ao laboratório para as análises subseqüèntes.

\subsection{Vigor de rebrota}

o vigor de rebrota foi avaliado através da matéria seca produzida 28 dias após o corte, para determinar o ganho acumulativo de matéria seca. Para essa avaliação, o corte foi feito também a $10 \mathrm{~cm}$ da superfície do solo. A área experimental utilizada foi a mesma área de $1,50 \mathrm{~m}^{2}$ usada no ganho acumulativo de matéria seca. A produção de matéria seca foi estimada em $\mathrm{kg} / \mathrm{ha}$. O vigor de rebrota foi avaliado até a idade de 112 dias, pois, a partir daí o período de baixa pluviosidade ocorrido reduziu muito as rebrotas. 


\subsection{Altura da cultura}

A altura da cultura foi tomada na data de cor te, para se avaliar o ganho acumulativo, com o auxílio de uma mira topográfica, tomando-se três posições dentro da parcela . Para a leitura era visado na mira topográfica o ponto da curvatura das lâminas foliares. Essa variável foi avaliada até a idade de 196 dias, pois, em seguida houve emissão de inflorescència, o que impedia uma boa medida.

\subsection{Número de perfilhos por área e peso médio dos perfilhos}

o número de perfilhos por área foi avaliado em uma área correspondente a $0,50 \mathrm{~m}^{2}$ : em cada parcela. Esta área de $0,50 \mathrm{~m}^{2}$ e a de $1,50 \mathrm{~m}^{2}$ utilizadas na avaliação da matéria seca, foram situadas na parcela experimental de 5,00 x 2,25 $\mathrm{m}^{2}$, de maneira casualizada. Na área para avaliação do número de perfilhos a forragem foi cortada o mais rente possivel do solo. Após a eliminação do material seco os perfilhos foram contados. Foram considerados os perfilhos de origem basilar (que emergiam da base da planta) e aérea (que emergiam de gemas aéreàs), porém, após o final do experimento decidiu-se não considerar os perfilhos aéreos, devido à sua baixa ocorrência nos três capins.

Para a determinação do peso médio dos perfiIhos, foi utilizado o material colhido para contagem do número de perfilhos. Após a secagem, for am retiradas amostras de de- 
terminação da porcentagem da matéria seca. A amostra retirada recebeu o mesmo tratamento das outras já descritas.

o peso seco médio dos perfilhos em gramas foi estimado dividindo-se o peso seco do total de perfilhos pelo número de perfilhos da amostra.

\subsection{Relação lâmina:haste e altura do meristema apical}

Para a determinação da relação lâmina:haste em matéria seca, o perfilho foi separado nas duas frações. A fração haste correspondeu ao colmo propriamente dito, mais as bainhas das folhas, além de folhas jovens ainda não emergidas cortando-se a haste no seu topo, na altura da última lígula ví sível. Á separação àa läinina foi feita na altura da ígula.

Os perfilhos utilizados nesta avaliação foram obtidos dos perfilhos coletados para a estimativa do seu número por área, após o agrupamento deste por tamanho. Desta maneira, procurou-se retirar uma amostra representativa de todos os tamanhos de perfilhos que ocorriam na cultura, guardan do também a proporcionalidade dos mesmos.

Para avaliação da altura do meristema apical foi retirada uma amostra de 30 perfilhos da amostra para determinação da relação lâmina:haste. Nesta amostragem procurou-se selecionar os perfilhos por tamanho, de maneira à representar proporcionalmente todos os tamanhos de perfilhos de cada corte. Para medição da altura os perfilhos foram seccionados longitudinalmente para localização da gema apical, to- 
mando-se, então, a distância desta gema à base do colmo, com o auxílio de uma régua. Desta maneira, cada observação de altura do meristema apical correspondeu à média de 30 leituras. As observações foram efetuadas até a idade de 196 dias, em razão da passagem dos capins da fase vegetativa para reprodutiva.

3.6. Teores de matéria seca, proteína bruta e fibra bruta

As determinações de matéria seca e fibra bruta foram efetuadas segundo ASSOCIATION OF OFFICIAL AGRICULTURAL CHEMISTS (1960).

Os teores de proteína bruta $\left(\frac{\circ}{2} \times 6,25\right)$ foram determinadas pelo método de análise de nitrogênio semi-micro Kjeldahl, usando o óxido de mercúrio como catalizador (LOTT et alii, 1956).

Os teores de matéria seca a $100^{\circ} \mathrm{C}$ e proteína bruta na matéria seca foram determinados nas amostras de planta inteira, lâmina, haste. A fibra bruta na matéria seca foi determinada somente na amostra da planta inteira. Todas as variáveis foram avaliadas na matéria seca a $100^{\circ} \mathrm{C}$.

3.7. Participação porcentual da proteína da lâmina e da haste em relação à planta inteira

Essas participações foram calculadas utilizando-se as produções de matéria seca, os teores de proteína na amostra de planta inteira, lâmina e haste erelação lâmina:haste. 
3.8. Teores de conteúdo celular, fibra insolúvel em detergente neutro, fibra insolúvel em detergente ácido, hemicelulose, celulose e lignina

Essas análises forám determinadas com base na matéria seca seguindo os métodos descritos por GOERING e VAN SOEST (1970). Os teores de conteúdo celular, celulose e hemicelulose foram calculados por diferença.

Essas determinações foram realizadas até a idade de 140 dias, pois forragens acima dessa idade são de baixo valor para alimentação animal e as análises realizadas são de custo muito elevado.

3.9. Digestibilidade "in vitro" da matéria seca

Essa análise foi realizada segundo o método de TILLEY e TERRY (1963). As determinações foram efetuadas somente nas amostras de planta inteira. As análises foram realizadas até a idade de 140 dias, pelo motivo já exposto.

3.10. Minerais

Os minerais fósforo, cálcio, magnésio, potássio, enxofre, cobre, ferro,manganès e zinco, foram analisados somente nas amostras de lâmina foliar a partir da extração nitro-perclórica (SARRUGE e HAAG, 1974).

o fósforo foi determinado pelo método de vanádio-molibdato de amōnio, com leitura no colorímetro foto- 
elétrico Klett-Summerson (SARRUGE e HAAG, 1974).

Os demais foram determinados pelo método

de espectrofotometria de absorção atômica Perkin-Elmer, num aparelho modelo 306 (PERKIN-ELMER CORPORATION, 1976).

Para a determinação do cálcio fez-se uma diluição inicial da alíquota do extrato com óxido de lantânio.

As análises de minerais na làmina foliar foram efetuadas até a idade de 140 dias, pelos motivos já mencionados.

O fósforo, cálcio, magnésio, potássio. e enxofre foram determinados em porcentagem da matéria seca a $100^{\circ} \mathrm{C}$, enquantoo cobre, ferro, manganès e zinco foram determinados em ppm na matéria seca.

A relação $\mathrm{N}: \mathrm{S}$ foi calculada mediante as porcen tagens de nitrogênio e enxofre da amostra da lámina. 
4. RESUltados E Discuss Ão

4.1. Comparação pelo teste Tukey $(P<0,05)$, das médias dos capins e das médias dentro de cada idade de corte.

\subsubsection{Ganho acumulativo de matéria seca}

Conforme já mencionado verifica-se pela Tabela 2 a ocorrência de um período de baixa precipitação pluvial entre os meses de janeiro e março $(170,7 \mathrm{~mm})$.

Todavia, o aparecimento de grande quantidade de forragem seca em todos os capins a partir da idade de 168 dias de crescimento pode ter sido agravada pela ocorrência dós mematóides Pratylenchus zea, Pratichodorus minor, Helicotylenchus dihystera e Xiphilema sp., identificados nos três capins por técnicos da Escola Superior de Agricultura "Luiz de Quei- 
roz", em Piracicaba, SP, e do Instituto Agronômico da Secretaria de Agricultura e Abastecimento do Estado de São Paulo, em Campinas, SP. Como conseqüència, a produção de matéria seca dos capins foi afetada.

A tabela 4 mostra as produções médias de MST, MSV e MSS dos capins estudados.

A análise de variância mostrou que os capins não diferiram entre si pela produção de MST.

Todavia, para a produção de MSV (Tabela 4) a análise de variância mostrou que os capins diferiram entre si, $(\mathrm{P}<0,05)$. A comparação das médias revelou que os capins tobiatã e K-187 B não diferiram quanto à produção de MSV. Todavia, a produção de MSV do capim coloniäo foi superior a do capim tobiatã, não diferindo porém da produção do K-187 B.

Para as produções médias de MSS, (Tabela 4), a análise de variância mostrou que os capins não diferiram entre si.

A produção de MST de cada capim aos 252 dias de crescimento, foi ao redor de $18.000 \mathrm{~kg} / \mathrm{ha}$ (Tabela 4). Essa produção é menor do que a verificada para o capim colonião em crescimento contínuo (PEDREIRA, 1965/66). Entretanto, no perío do inicial de crescimento deste ensaio, fase vegetativa, ocorreram produções diárias de MST e MSV bastante elevadas. Entre as idades de 56 e 84 dias observaram-se produções diárias de $172,67,132,50$ e $107,88 \mathrm{~kg} / \mathrm{ha}$, respectivamente para o colonião, tobiatã e K-187 B. Para o período seguinte de crescimento, en- 


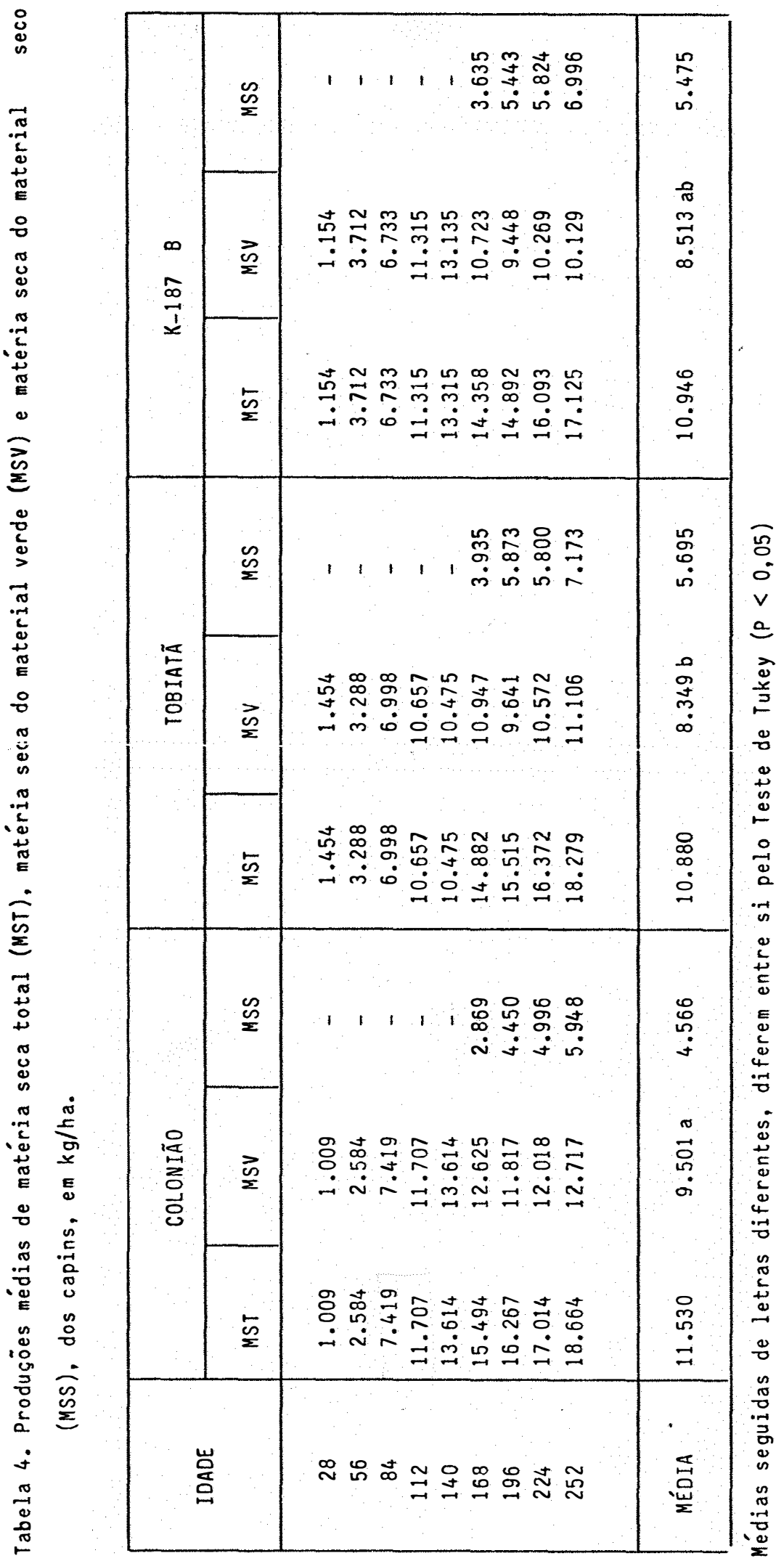


tre as idades de 84 e 112 dias, essas produções foram de 153,16; 130,68 e $163,66 \mathrm{~kg} / \mathrm{ha}$. Essas taxas diárias são superiores às obtidas por GOMIDE et alii (1979 a) e GOMIDE e ZAGO (1980). Contudo, ainda que produções diárias obtidas neste trabalho possam ser consideradas altas para as nossas condições, verifica-se que o potencial de produção dessas forrageiras é ainda bem superior. BOYERS (1971), trabalhando com O capim K-187 B no Senegal, com altas aplicações de nitrogênio e potássio em ensaios de irrigação, verificou produções anuais ao redor de $43.000 \mathrm{~kg} / \mathrm{ha}$ de MS, com produções diárias de $192 \mathrm{~kg} / \mathrm{ha}$ de MS.

4.1.2. Número de perfilhos por área, peso médio dos perfilhos, relação lâmina:haste, altura da cultura, altura do meristema apical e vigor de rebrota

A Tabela 5 mostra as médias do número de perfiIhos por área e do peso médio dos perfilhos, dos capins estudados.

A análise de variância para o número de perfilhos por área mostrou que os capins diferiram entre si $(P<0,01)$.

Pela comparação das médias verificou-se que o capim tobiatã apresentou número mais älto de perfilhos do que os capins colonião e K-187 B, que não diferiram para essa variável. 
A comparação das médias do número de perfilhos, dentro de cada idade, mostrou que aos $84 ; 140 ; 168 ; 196 ; 224$ e 252 dias, portanto mais acentuadamente nas idades avançadas, os três capins não diferiram. Para a idade de 28 dias, os capins colonião e tobiatã apresentaram maior número de perfilhos do que o K-187 B. Nas idades de 56 e 112 dias, 0 número de perfilhos dos capins tobiatã e K-187 B foram mais elevados do que o do colonião. Ainda, aos 112 dias, 0 K-187 B teve maior número de perfilhos do que o colonião.

Os resultados para número de perfilhos obtidos neste trabalho foram inferiores aos registrados por PEDREIRA $(1965 / 66)$ para o capim colonião.

Tabela 5. Médias do número de perfilhos (NOP) em $0,50 \mathrm{~m}^{2}$ e do peso médio dos perfilhos (PMP) em gramas de matéria seca, dos capins estudados

\begin{tabular}{|c|c|c|c|c|c|c|}
\hline \multirow{3}{*}{ IDADE } & \multicolumn{6}{|c|}{ CAPINS } \\
\hline & \multicolumn{2}{|c|}{ COLONIÃO } & \multicolumn{2}{|c|}{ TOBIATÃ } & \multicolumn{2}{|c|}{$K-187 \quad B$} \\
\hline & No $P$ & PMP & $N O P$ & PMP & NO $P$ & PMP \\
\hline 28 & 353 a & 0,30 & 359 & 0,35 & 236 & 0,55 \\
\hline 56 & $245 b$ & 1,90 & 323 & 1,30 & 315 & 0,95 \\
\hline 84 & $196 a$ & 2,55 & 228 & 2,30 & 200 & 2,15 \\
\hline 112 & $101 \mathrm{c}$ & 7,75 & 215 & 3,95 & 160 & 4,10 \\
\hline 140 & $101 \mathrm{a}$ & 9,10 & 135 & 5,95 & 91 & 7,80 \\
\hline 168 & $111 \mathrm{a}$ & 8,45 & 115 & 5,75 & 84 & 9,05 \\
\hline 196 & $90 \mathrm{a}$ & 9,95 & 70 & 7,95 & 72 & 9,50 \\
\hline 224 & $70 a$ & 10,05 & 57 & 7,85 & 67 & 9,90 \\
\hline 252 & $61 \mathrm{a}$ & 16,75 & 44 & 12,15 & 45 & 13,20 \\
\hline MÉDIA & $148 \mathrm{~b}$ & $7,42 \mathrm{a}$ & 172 & $5,25 b$ & 141 & $6,38 a b$ \\
\hline
\end{tabular}

Médias seguidas de letras diferentes, na horizontal, diferem entre si pelo teste de Tukey $(p<0,05)$. 
Este trabalho também mostra que os maiores rendimentos de matéria seca estão associados com o maior peso individual dos perfilhos e não com o maior número destes, estando de acordo com PEDREIRA (1965/66), Knight (1955) citado por PEDREIRA (1965) e PEDREIRA e BOIN (1969). Embora CORSI (1972) afirme que o perfilhamento pode aumentar a produção de matéria seca, MECELIS (1979) verificou em experimento com o capim co-’ lonião, cortado em diferentes freqüências e alturas, que a pro dução de matéria seca tinha uma correlação negativa com o número de perfilhos. Os resultados de PEDREIRA (1973) sobre a estacionalidade da produção de diversos capins tropicais, confirmam essa hipótese. Pois, para o capim colonião o autor não encontrou diferença significativa cntro o número de perfilhos no verão e no inverno; contudo no verão foram mais pesados do que no inverno.

Para as médias do peso médio dos perfilhos (Tâ bela 5) a análise de variância revelou que os capins diferiram entresi $(P<0,01)$.

A comparação das médias do peso médio dos perfilhos mostrou que o K-187 B não diferiu do colonião no entanto, o colonião apresentou perfilhos mais pesados do que o tobiatã.

A Tabela 6 mostra as médias da relação lâmina: haste e da altura da cultura, dos capins estudados.

A análise de variância revelou que os capins diferiram entre si para a relação lâmina:haste $(P<0,01)$. 
comparação das médias mostrou que os capins tobiatã e K-187 B não diferiram e ambos foram superiores ao colonião.

Tabela 6. Médias das relações lâmina:haste (L:H) em matéria seca, e das alturas da cultura $(H C)$, em $\mathrm{cm}$, dos capins estudados.

\begin{tabular}{|c|c|c|c|c|c|c|}
\hline \multirow{2}{*}{ IDADE } & \multicolumn{2}{|c|}{ COLONIÃO } & \multicolumn{2}{|c|}{ TOBIATÃ } & \multicolumn{2}{|c|}{$K-187 \mathrm{~B}$} \\
\hline & $L: H$ & HC & $L: H$ & $H C$ & $L: H$ & $\mathrm{HC}$ \\
\hline 28 & 1,20 & 33 & 1,25 & 49 & 1,25 & 45 \\
\hline 56 & 1,55 & 98 & 1,75 & 99 & 1,65 & 82 \\
\hline 84 & 1,15 & 130 & 1,40 & 136 & 1,35 & 138 \\
\hline 112 & 0,75 & 182 & 1,30 & 167 & 1,25 & 157 \\
\hline 140 & 0,80 & 190 & 1,00 & 181 & 0,90 & 185 \\
\hline 168 & 0,60 & 196 & 0,85 & 166 & 0,65 & 198 \\
\hline 196 & 0,45 & 199 & 0,65 & 183 & 0,60 & 185 \\
\hline 224 & 0,45 & - & 0,65 & - & 0,60 & - \\
\hline 252 & 0,25 & - & 0,40 & - & 0,30 & - \\
\hline MÉDIA & $0,80 \mathrm{~b}$ & 147 & 1,03 & 141 & 0,95 & 140 \\
\hline
\end{tabular}

Médias seguidas de letras diferentes, diferem entre si pelo Teste de Tukey $(P<0,05)$.

Os valores de relação lâmina:haste observadas no presente experimento foram superiores aos obtidos por PEDREIRA (1965/66) para o colonião.

Tomando-se por base os resultados de MINSON (1971), que relaciona o consumo voluntário de capins do genéro Panicum à proporção de lämina foliar, os capins tobiatã e K-187 B, neste ensaio, apresentariam consumos maiores do que os verificados para o colonião.

Segundo PRINE e BURTON.(1956), a relação lâmina:haste é inversamente relacionada com o tamanho do perfiTho. Isso confirma os resultados deste trabalho, pois, para 
maiores alturas da cultura verificaram-se menores relações lâmina: haste.

Para as médias da altura da cultura (Tabela 6), a análise de variância revelou que os capins não diferiram entre si.

A Tabela 7 mostra as médias da altura do meristema apical e do vigor de rebrota, dos capins estudados.

A análise de variância revelou que os capins diferiram para altura do meristema apical $(P<0,01)$. Efetuando-se a comparação das médias da altura do meristema apical, verificou-se que o capim tobiatã apresentou menor valor que 0 capim colonião, porém, não diferiu do capim K-187 B. Os capins

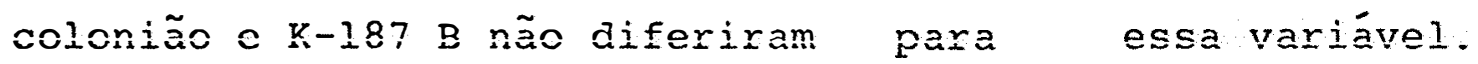

Tabela 7. Médias das alturas do meristema apical (HMA), em $\mathrm{cm}$, e das produções de matéria seca da rebrota (VR), em $\mathrm{K} / \mathrm{ha}$, dos capins estudados.

\begin{tabular}{|c|c|c|c|c|c|c|}
\hline \multirow{3}{*}{ IDADE } & \multicolumn{6}{|c|}{ CAPINS } \\
\hline & \multicolumn{2}{|c|}{ COLONIÃO } & \multicolumn{2}{|c|}{ TOB IATÃ } & \multicolumn{2}{|c|}{$K-187 B$} \\
\hline & HMA & VR & HMA & VR & HMA & VR \\
\hline 28 & 1 & 399 & 0,5 & 1.161 & 0,5 & 977 \\
\hline 56 & 2 & 642 & 1 & 976 & 1 & 936 \\
\hline 84 & 23 & 1.382 & 14 & 1.547 & 11 & 975 \\
\hline 112 & 60 & 648 & 39 & 688 & 34 & 944 \\
\hline 140 & 77 & - & 63 & - & 69 & - \\
\hline 168 & 74 & - & 62 & - & 85 & - \\
\hline 196 & 95 & - & 84 & - & 84 & - \\
\hline MÉOIA & $48 a$ & 768 & $38 \mathrm{~b}$ & 1.093 & $42 a b$ & 958 \\
\hline
\end{tabular}

Médias seguidas de letras diferentes, diferem entre si pelo Teste de Tukey $(P<0,05)$. 
Os dados de altura do meristema apical obtidos neste trabalho foram menores que os de GOMIDE et alii (1979 b ) e NASCIMENTO et alii (1979) para o capim colonião. Os menores valores para elevação do meristema apical observado neste trabalho pode ter sido devido aos cortes de uniformização realiza da em junho e setembro de 1983.

Para as médias das produções de matéria seca da rebrota (vigor de rebrota), (Tabela 7), a análise de variân cia revelou que os capins não diferiram entre si.

As quantidades de matéria seca obtidas na avaliação do vigor de rebrota são próximas das encontradas por GOMIDE et alii (1979 b) e GOMIDE e ZAGO (1980). Contudo, pode-se verificar pela Tabela 7 que o vigor de rebrota pariece não estar relacionado com a decapitação de perfilhos, conforme mostrado por GOMIDE et alii (1979 b) e GOMIDE e ZAGO (1980) , embora neste trabalho não tenham sido feitas correlações devidas para essa comprovação. Verifica-se que o vigor de rebrota aos 84 dias foi superior aos demais, sendo que principalmente para o colonião, segundo GOMIDE et alii(1979 b) e GOMIDE e ZAGO (1980), deveria ser menor do que os dos cortes anteriores. Pode-se explicar o fato pela observação de que os perfilhos do capim colonião se desenvolveram em uma posição bastante oblíqua o que reduz a altura do meristema apical em relação à superfície do terreno. Assim pode-se sugerir que a maior decaptação tenha ocorrido na idade de 112 dias, no qual houve redução do vigor de rebrota. 
4.1.3. Teores de matéria seca, fibra bruta e proteína bruta, e participação porcentual da proteína bruta da lâmina e da haste em relação à planta inteira

A Tabela 8 mostra as médias dos teores de matéria seca e fibra bruta dos capins estudados.

A análise de variância dos teores de matéria se ca revelou que os capins diferiram entre si $(P<0,05)$. A comparação das médias revelou que o K-187 B não diferiu do tobiatã e nem do colonião; este porém, apresentou maiores teores de matéría seca do que o tobiatã.

Tabela 8. Médias dos teores de matéria seca (\% MS) e fibra bruta (\% FB) dos capins

\begin{tabular}{|c|c|c|c|c|c|c|}
\hline \multirow{2}{*}{ IOADE } & \multicolumn{2}{|c|}{ COLONIÃO } & \multicolumn{2}{|c|}{ TOBIATÃ } & \multicolumn{2}{|c|}{$K-187 B$} \\
\hline & $\%$ MS & $\%$ FB & $\%$ MS & $\% F B$ & $\%$ MS & $\% \mathrm{FB}$ \\
\hline 28 & 23,95 & $28,05 b$ & 21,50 & $37,35^{a}$ & 23,20 & $32,40^{a}$ \\
\hline 56 & 22,90 & $38,05^{a}$ & 24,85 & $37,80^{a}$ & 22,40 & $39,50^{a}$ \\
\hline 84 & 23,65 & $40,55^{b}$ & 24,15 & $47,65^{\mathrm{a}}$ & 23,05 & $42,35^{b}$ \\
\hline 112 & 28,45 & $44,70^{\mathrm{a}}$ & 23,95 & $46,25^{a}$ & 26,10 & $44,20^{a}$ \\
\hline 140 & 31,85 & $45,75^{a}$ & 28,00 & $44,00 \mathrm{ab}$ & 29,95 & $40,65^{b}$ \\
\hline 168 & 35,85 & $46,60^{a}$ & 32,30 & $46,20 \mathrm{ab}$ & 30,05 & $42,40^{b}$ \\
\hline 196 & 38,45 & $48,05^{a}$ & 35,00 & $49,10^{a}$ & 35,60 & $46,80^{a}$ \\
\hline 224 & 36,30 & $49,20^{a}$ & 32,25 & $48,55^{\mathrm{a}}$ & 33,75 & $49,30^{a}$ \\
\hline 252 & 45,75 & $49,30^{a}$ & 44,85 & $48,25^{a}$ & 48,80 & $47,45^{a}$ \\
\hline MÉDIA & $31,95 \mathrm{a}$ & $43,36 b$ & $29,65 \mathrm{~b}$ & $44,68 \mathrm{a}$ & $30,32 \mathrm{ab}$ & $42,78 b$ \\
\hline
\end{tabular}

Médias seguidas de letras diferentes, na horizontal, diferem entre si pelo Teste de Tukey $(p<0,05)$

Os resultados de teor de matéria seca obtidos neste trabalho são semelhantes aos de PEDREIRA (1965/66) para 
o capim-colonião.

Embora as diferenças entre os capins para os teores de matéria seca sejam pequenas, era de se esperar que o tobiatã e o K-187 B apresentassem teores mais elevados, uma vez que eles apresentaram uma maior relação lâmina:haste (Tabela 6) concordando com os resultados de PEDREIRA e SILVEIRA (1972), os quais verificaram teores mais elevados de matéria seca para as lâminas do que para as hastes.

Com referência às médias dos teores de fibra bruta, a análise de variância mostrou que os capins diferiram entre si, $(P<0,01)$. A comparação das médias mostrou que os capins colonião e K-187 B apresentaram teores de fibra bruta inferiores ac tobiatã (Tabela 8).

Quando os capins foram comparados dentro de cada idade, os resultados mostraram que os capins tobiatã e $\mathrm{K}-187 \mathrm{~B}$ não diferiram em 8 das 9 idades estudadas. Apenas na idade de 84 dias o teor de fibra bruta foi mais elevado para o tobiatã que nos outros dois capins. O capim colonião na idade de 28 dias apresentou teores mais baixo do que os capins tobiatã e K-187 B. O teor de fibra bruta do capim colonião na idade de 84 dias foi menor do que o do tobiatã, porém não diferiu do apresentado pelo $\mathrm{K}-187 \mathrm{~B}$. Nas idades restantes os capins colonião e tobiatã não diferiram para essa variável. Os teores de fibra bruta do capim colonião nas idades de 140 e 168 dias foram superiores aos do K-187 B (Tabela 8). 
Os resultados de fibra bruta deste trabalho são semelhantes aos obtidos por PEDREIRA e SILVEIRA (1972).

Conforme afirma GOMIDE (1973) a fibra bruta e a proteína bruta variaram em proporções inversa na forragem.

A Tabela 9 apresenta as médias dos teores de proteína bruta da planta inteira, da lâmina foliar e da haste dos capins estudados.

A análise de variância dos teores de proteína bru ta mostrou que os capins não diferiram entre si.

Os teores de proteina bruta da planta inteira observados neste trabalho são semelhantes aos encontrados por PEDREIRA e SILVEIRA (1972) e GOMIDE et alii (1979 a).

Para as médias dos teores de proteina bruta das lâminas foliares (Tabela 9), a análise de variância mostrou que os capins não diferiram entre si.

Os teores de proteina bruta das lâminas foliares encontrados neste trabalho são semelhantes aos obtidos por PEDREIRA e SILVEIRA (1972) para o capim colonião.

Quanto às médias dos teores de proteína bruta da haste, (Tabela 9), a análise de variância revelou que os capins não diferiram. Esses resultados de proteína bruta de haste são semelhantes aos obtidos por PEDREIRA e SILVEIRA (1972).

Contudo, não só o teor de proteína bruta da forragem é importante, visto que em condições de pastagens, onde é dada ao animal a oportunidade de selecionar, a lâmina foliar é geralmente ingerida em maiores proporções do que a haste (MIN- 


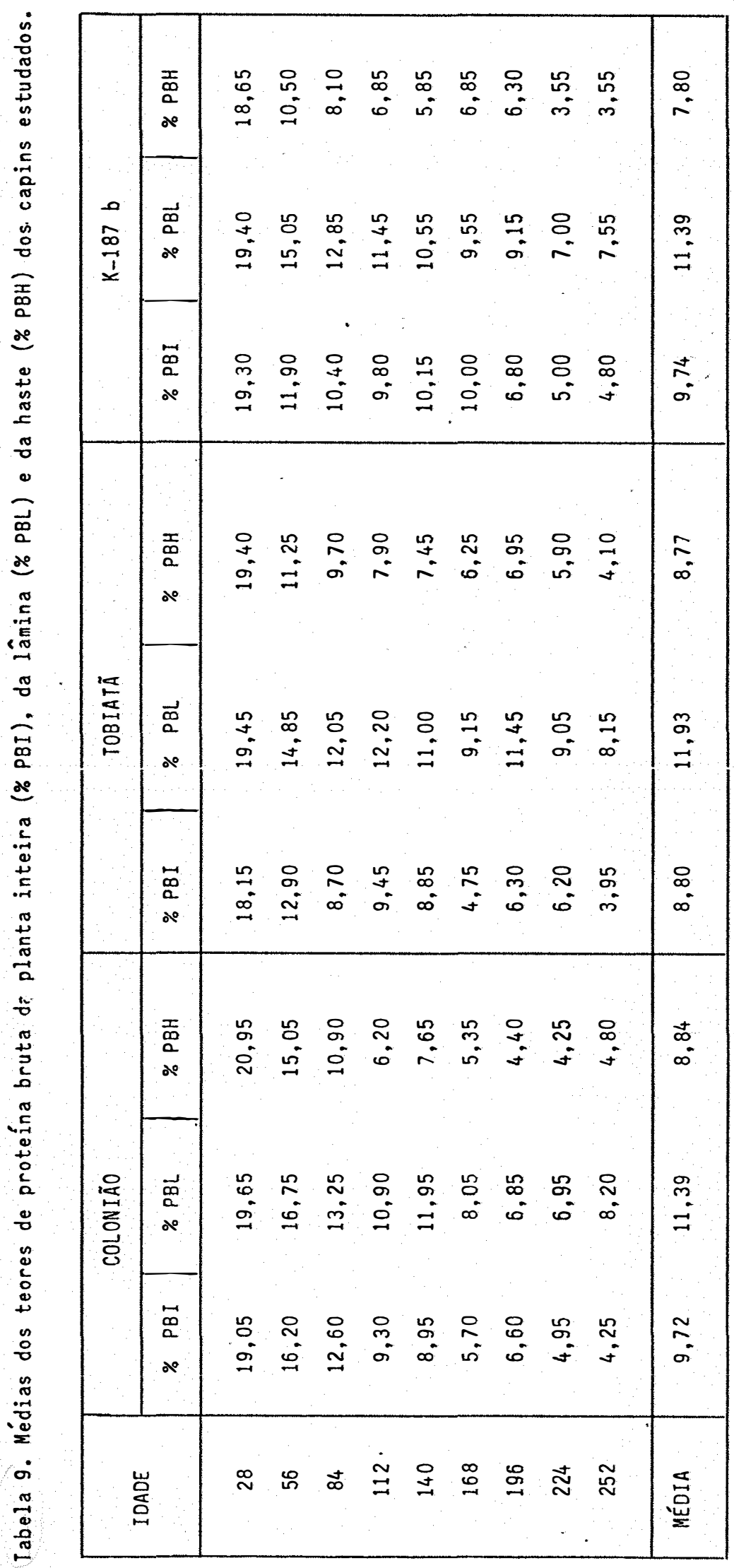


SoN, 1980). Além disso, a digestibilidade da lâmina é maior do que a da haste (HACKER e MINSON, 1981). Neste sentido torna-se importante conhecer a participação porcentual de proteína bruta da lâmina e da haste em relação à planta inteira.

A Tabela 10 apresenta as médias das participações porcentuais de proteína bruta da lâmina e de haste em relação à planta inteira, dos capins estudados.

As análises de variância dessas variáveis revelaram que os capins diferiram entre si $(P<0,01)$.

Nota-se que embora não tivessem ocorrido diferenças entre capins na análise de variância para os teores de proteína bruta da planta inteira, da lâmina foliar e da haste, diferenças significativas foram encontradas, quando se levou em conta a participação porcentual de proteína bruta da lámina e da haste em relação à planta inteira.

Quando os capins foram comparados pela média, verificou-se que o tobiatã e o K-187 B não diferiram quanto às participações porcentuais de proteína bruta de lâmina e de haste em relação à planta inteira. Com referência ao colonião, pode-se notar que o mesmo foi inferior aos demais quanto à participação porcentual de proteína bruta de lâmina e superior quanto à participação porcentual de proteína bruta de haste (Tabela $10)$. 


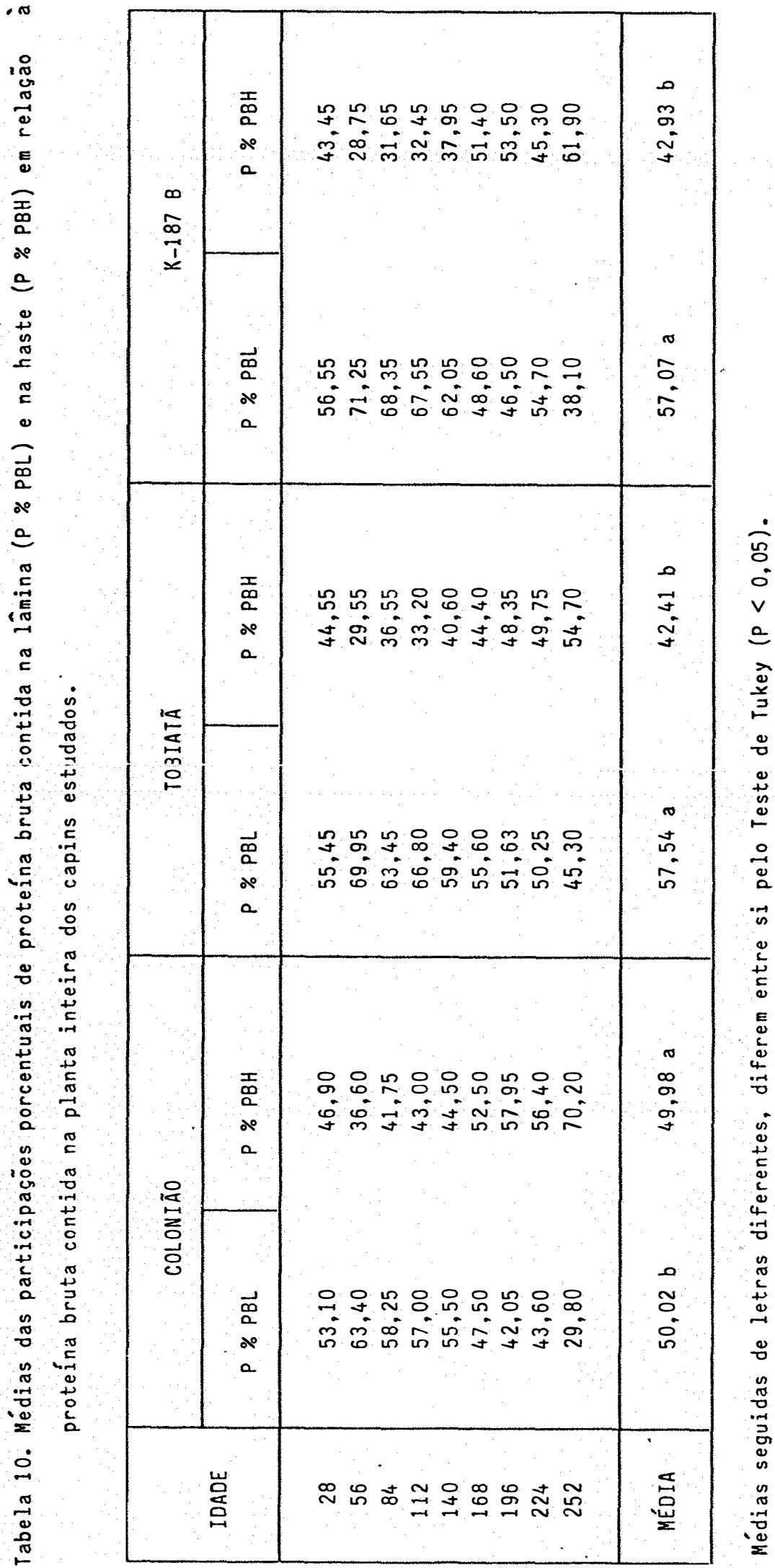


4.1.4. Teores de conteúdo celular, fibra insolúvel em detergente neutro, fibra insolúvel em detergente ácido, hemicelulose, celulose, lignina e digestibilidade "in vitro" da matéria seca

A Tabela 11 apresenta as médias dos teores de conteúdo celular, fibra insolúvel em detergente neutro, e fibra insolúvel em detergente ácido, dos capins estudados.

A análise de variância dos teores de conteúdo celular mostrou que os capins não diferiram entre si.

Os teores de conteúdo celular obtidos neste trabalho são inferiores aos encontrados por ANDRADE (1973) para o capim colonião, contudo, ainda estão pröximos da variaçäo normal para forrageiras tropicais, pois, THOMAS (1982) cita úma variação de 58 a $80 \%$ para a fibra insolúvel em detergente neutro.

Com referência às médias dos teores de fibra insolúvel em detergente neutro, (Tabela ll) a anạlise de variân cia revelou que os capins não diferiram entre si.

Os dados obtidos neste trabalho para fibra insolúvel em detergente neutro foram mais elevados do que os obtidos por ANDRADE (1973) para o capim colonião; todavia, estão próximos dos encontrados por FLORIO (1976) de 70 a $80 \%$. Segundo resultados de VAN SOEST (1965), os valores de fibra insolúvel em detergente neutro encontrados neste trabalho limitariam 


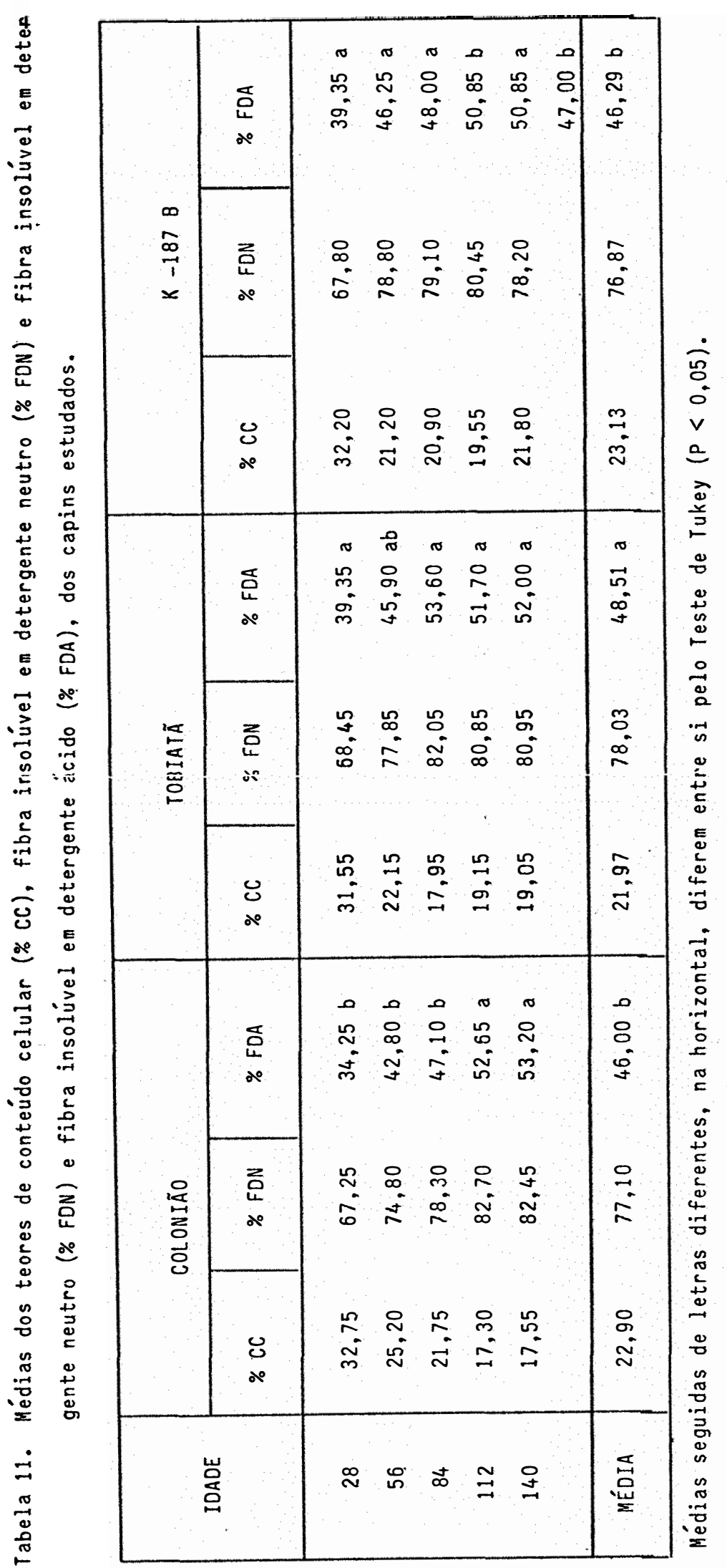


o consumo dos capins estudados.

Quanto às médias dos teores de fibra insolúvel em detergente ácido, (Tabela ll) a análise de variância mostrou que os capins diferiram entre si $(P<0,01)$. A comparação das médias revelou que os capin's colonião e K-187 B não dí feriram e foram inferiores ao tobiatã. Todavia, pode-se notar que para o tobiatã na idade de 84 dias e para o K-187 B na ida de de 140 dias, os teores de fibra insolúvel em detergente ácí do não seguiram a tendência mostrada. Esta poderia ser a causa da diferença ocorrida para esses capins uma vez que os teores dessa fração para as outras idades são bastantes semelhantes para os dois capins. Por outro lado, verifica-se que para as idades de 28 e 56 dias os capins tobiatã e K-187 B apresentaram teores de fibra insolúvel em detergente ácido superiores ao colonião, embora na idade de 56 dias o teor obtido para o tobiatã não tenha sido estatisticamente diferente do apresentado pelo colonião ( Tabela 11).

Os teores de fibra insolúvel em detergente ácí do são semelhantes aos obtidos por ANDRADE (1973) para o capim colonião.

A Tabela 12 mostra as médias dos teores de hemicelulose, celulose e lignina, dos capins estudados.

A análise de variância dos teores de hemicelulose, revelou que os capins diferiram entre si $(\mathrm{P}<0,05)$. Com parando-se as médias verifica-se que o capim tobiatã foi seme- 


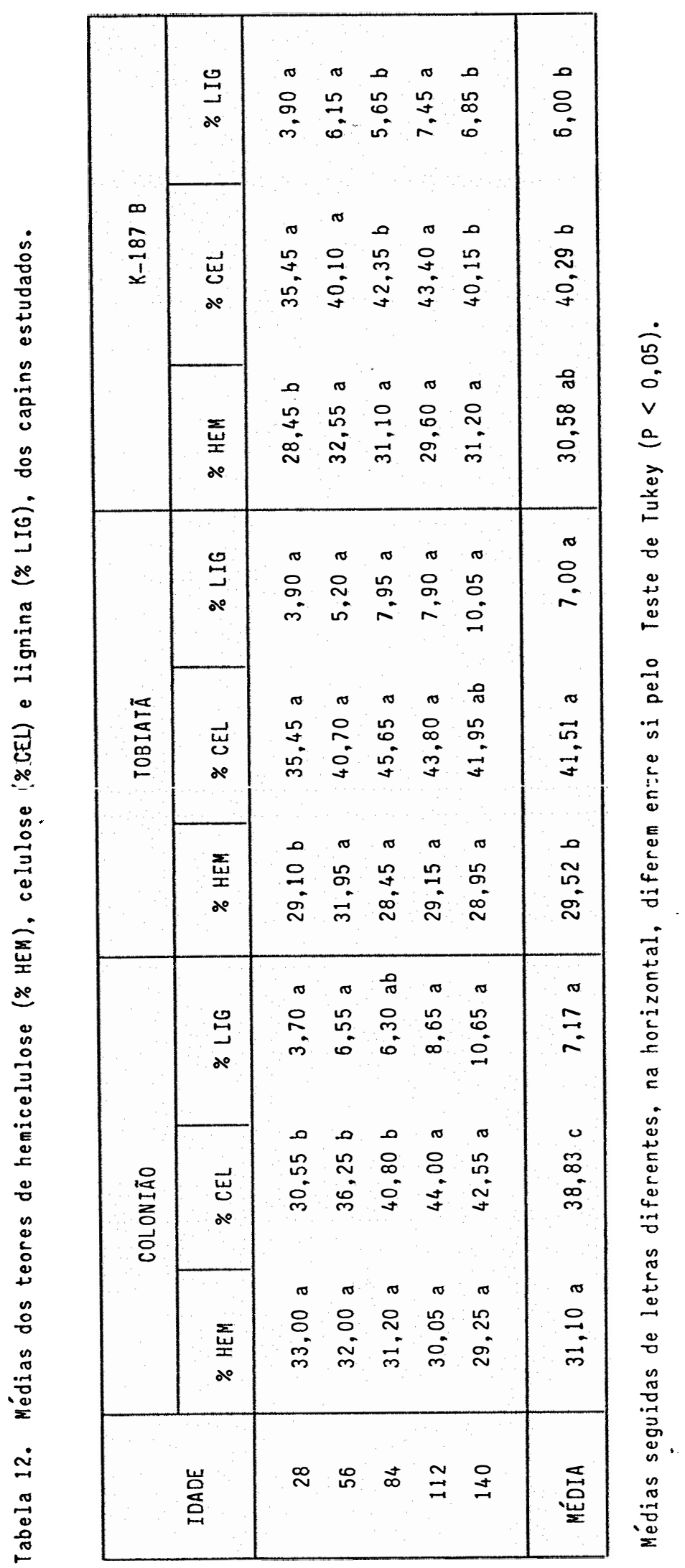


lhante ao K-187 B e inferior ao colonião, o qual, por sua vez, foi semelhante ao $\mathrm{K}-187 \mathrm{~B}$.

$\mathrm{Na}$ comparação dentro de cada idade verificou-se que os capins tobiatã e K-187 B não diferiram para o teor de hemicelulose em todas as idades estudadas, (Tabela 12). Comparando-se os três capins nota-se que somente na idade de 28 dias é que os teores de hemicelulose dos capins tobiatã e K-187 B são menores que os do colonião. Para as outras idades, os três capins não diferiram quanto à essa variável.

Os teores de hemicelulose obtidos neste trabalho são mais altos que os observados por ANDRADE (1973) para o capim colonião.

Quanto às médias auos leores de celulose ítábela 12) a análise de variância revelou que os capins diferiram entre si, $(P<0,01)$. Na comparação das médias, verificou-se que o capim tobiatã foi superior ao $\mathrm{K}-187 \mathrm{~B}$, o qual, por sua vez, foi superior ao capim colonião (Tabela 12).

A comparação dos capins dentro de cada idade, revelou que para os 28 e 56 dias os capins tobiatãe K-187 B não diferiram entre si mas foram superiores ao colonião quanto. ao teor de celulose (Tabela 12). Comparando-se o tobiatã e o K-187 $B$, verifica-se pela (Tabela 12) que os teores de celulose na idade de 84 dias para o tobiatã e 140 para $\circ$ K-187 B não seguiram a tendência mostrada. Esse fato, a exemplo do que ocorreu para os teores de FDA, provavelmente tenha contribuído para estabelecer as diferenças entre esses capins. 
Os teores de celulose observados neste trabalho são semelhantes aos de ANDRADE (1973) e GOMIDE e ZAGO (1980), para o capim colonião.

Com referência às médias dos teores de lignina (Tabela 12), a análise de variância revelou que os capins diferiram entre si $(P<0,01)$. A comparação das médias revelou que os capins colonião e tobiatã não diferiram entre si, mas apresentaram teores de lignina mais elevados do que o K-187 B.

Comparando-se os capins dentro de cada idade

verificou-se que os mesmos não diferiram nas idades de 28, 56 e 112 dias. Na idade de 84 dias o teor de lignina do capim tobiatã foi mais elevado que o apresentado pelo capim K-187 B, porém, não diferiu do teor do capim colonião. Na idade de 140 dias o teor apresentado pelo capim K-187 B, foi menor que o dos capins colonião e tobiatã.

Os teores de lignina obtidos neste trabalho são semelhantes aos de ANDRADE (1973), para o capim colonião.

A Tabela 13 apresenta as médias das digestibilí dades "in vitro" da matéria seca dos capins estudados. A análise de variāncia revelou que os capins diferiram entre si, $(\mathrm{P}<0,01)$. Comparando-se as médias, verificou-se que o capim colonião apresentou digestibilidade "in vitro" maior do que os capins tobiatã e K-187 B. O capim tobiatã não diferiu do capim K-187 B para essa variável (Tabela 13).

A comparação dos capins dentro de cada idade mostrou que o colonião tem maior digestibilidade que o tobiatã 
e $\circ$ K-187 B na idade de 84 dias, e aos 28 dias é superior apenas ao K-187 B. Nas demais idades os três capins não diferiram. Cabe assinalar que os capins tobiatã e K-187 B não diferiram em nenhuma das idades estudadas.

Tabela 13. Médias das porcentagens de digestibilidade "in vitro" da matéria seca dos capins estudados.

\begin{tabular}{|c|c|c|c|}
\hline IDADE & COLONIÃO & TOBIATÃ & K-187 B \\
\hline 28 & $66,90 \mathrm{a}$ & $66,35 \mathrm{ab}$ & $61,95 \mathrm{~b}$ \\
56 & $61,00 \mathrm{a}$ & $57,40 \mathrm{a}$ & $57,95 \mathrm{a}$ \\
84 & $55,15 \mathrm{a}$ & $46,65 \mathrm{~b}$ & $50,15 \mathrm{~b}$ \\
112 & $45,60 \mathrm{a}$ & $45,80 \mathrm{a}$ & $46,75 \mathrm{a}$ \\
140 & $42,60 \mathrm{a}$ & $41,50 \mathrm{a}$ & $43,15 \mathrm{a}$ \\
\hline MÉOIA & & $51,00 \mathrm{~b}$ & $51,54 \mathrm{~b}$ \\
\hline
\end{tabular}

Médias seguidas de letras diferentes, na horizontal, diferem entre si pelo Teste de Tukey $(p<0,05)$.

Os resultados de digestibilidade "in vitro", da matéria seca obtidos neste trabalho são inferiores aos de GOMIDE et alii (1979 a) para o capim colonião.

\subsubsection{Teores de minerais}

A Tabela 14 apresenta as médias dos teores de fósforo e cálcio, nas lâminas foliares dos capins estudados.

A análise de variância dos teores de fósforo re velou que os capins não diferiram entre si. 
Tabela 14. Médias dos teores de fósforo (\% P) e de cálcio (\% Ca), das lâminas foliares dos capins estudados.

\begin{tabular}{|c|c|c|c|c|c|c|}
\hline \multirow{2}{*}{ IDADE } & \multicolumn{2}{|c|}{ COLONIÃO } & \multicolumn{2}{|c|}{ TOBIATÃ } & \multicolumn{2}{|c|}{$K-187$ B } \\
\hline & $\% p$ & $\% \mathrm{Ca}$ & $\% p$ & $\% \mathrm{Ca}$ & $\% \quad P$ & $\% \mathrm{Ca}$ \\
\hline 28 & 0,26 & 0,84 & 0,22 & 0,81 & 0,23 & 0,78 \\
\hline 56 & 0,24 & 0,88 & 0,22 & 0,69 & 0,22 & 0,74 \\
\hline 84 & 0,18 & 0,85 & 0,14 & 0,70 & 0,16 & 0,75 \\
\hline 112 & 0,15 & 0,67 & 0,17 & 0,78 & 0,16 & 0,76 \\
\hline 140 & 0,14 & 0,91 & 0,12 & 0,70 & 0,16 & 0,86 \\
\hline MÉOIA & 0,20 & 0,83 & 0,18 & 0,74 & 0,19 & 0,78 \\
\hline
\end{tabular}

Os teores de fósforo contidos nas lâminas folia res, obtidos neste trabalho, são mais elevados do que aqueles observados por GOMIDE et alii (1979 a) para a planta inteira de colonião, porém mais próximos dos resultados de PEDREIRA e SILVEIRA (1972) para a lâmina foliar do capim colonião.

Segundo as exigências de gado de corte, sugerida por Minson et alii (1967), citados por WHITEMAN (1980), somente nas idades de 28 e 56 dias os teores de fósforo nas làminas dos capins supririam as necessidades animais.

Para as médias dos teores de cálcio das làminas foliares (Tabela 14), a análise de variância mostrou que os capins não diferiram entre si.

Os teores de cálcio das láminas foliares obtidos neste trabalho, são mais elevados que os apresentados por 
GOMIDE et alii (1979 a) para a planta inteira e também que os obtidos por PEDREIRA e SILVEIRA (1972) para a lámina foliar do capim colonião.

Os teores de cálcio da lâmina foliar dos capins, obtidos neste trabalho, estão bem àcima das exigéncias de gado de corte, sugeridas por Minson et alii (1967), citados por WHITEMAN (1980).

A Tabela 15 apresenta as médias dos teores de mangnésio e potássio, das lâminas foliares dos capins estudados. A análise de variância dos teores de magnésio revelou que os capins não diferiram entre si.

Os teores de magnésio contido nas lâminas foliares dos capins, obtidos nosto trabalho, são mais elevados que os observados por GOMIDE et alii (1979 a) para a planta in teira de colonião.

Os teores de magnésio das lâminas foliares dos capins estudados são suficientes para suprir as exigéncias de gado de corte, segundo os requerimentos sugeridos por Minson et alii (1967), citados por WHITEMAN (1980).

Quanto às médias dos teores de potássio das lầminas foliares (Tabela 15), a análise de variância revelou que os capins diferiram entre si, $(\mathrm{P}<0,05)$.

A comparação das médias mostrou que o capim tobiatã não diferiu dos capins colonião e K-187 B. O capim colonião apresentou teores de potássio mais elevados que os do K-187 B (Tabela 15). 
Tabela 15. Médias dos teores dẹ magnésio $(\% g)$ e de potássio (\% K), das lâminas foliares dos capins estudados.

\begin{tabular}{|c|c|c|c|c|c|c|}
\hline \multirow{3}{*}{ IDADE } & \multicolumn{2}{|c|}{ COLONIÃO } & \multicolumn{3}{|c|}{ TOBIATÃ } & \multicolumn{2}{c|}{$K-187$ B } \\
\cline { 2 - 7 } & $\% \mathrm{Mg}$ & $\% \mathrm{~K}$ & $\% \mathrm{Mg}$ & $\% \mathrm{~K}$ & $\% \mathrm{Mg}$ & $\%$ \\
\hline \multirow{3}{*}{28} & & & & & & \\
56 & 0,47 & 2,47 & 0,38 & 2,03 & 0,42 & 1,56 \\
84 & 0,55 & 1,48 & 0,36 & 1,09 & 0,41 & 1,20 \\
112 & 0,46 & 1,32 & 0,38 & 1,19 & 0,42 & 0,96 \\
140 & 0,33 & 1,09 & 0,39 & 0,74 & 0,43 & 0,74 \\
& 0,39 & 0,95 & 0,39 & 0,93 & 0,47 & 0,88 \\
\hline MÉDIA & 0,44 & $1,46 \mathrm{a}$ & 0,38 & 1,20 ab & 0,45 & $1,07 \mathrm{~b}$ \\
\hline
\end{tabular}

Médias seguidas de letras diferentes, diferem entre si pelo Teste de Tukey, $(P<0,05)$.

ôs teores de potássio cuñituo nàs lâminas foliares dos capins, obtidos neste trabalho, são menores que os observados por GOMIDE et alii (1979 a) para a planta inteira de colonião. Embora menores, eles estão muito acima das exigências de gado de corte, sugerida por Minson et alii (1967) , citados por WHITEMAN (1980).

A Tabela 16 mostra as médias dos teores de enxofre e das relações N:S, das lâminas foliares dos capins estudados.

A análise de variância dos teores de enxofre, mostrou que os capins diferiram entre $\mathrm{si}(\mathrm{P}<0,01)$. A comparação das médias revelou que o capim tobiatã não diferiu do K-187 B e ambos apresentaram teores de enxofre superiores ao colonião (Tabela 16). 
Tabela 16. Médias dos teores de enxofre (\% S) e das relações nitrogênio:enxofre (N:S), das lâminas foliares dos capins estudados.

\begin{tabular}{|c|c|c|c|c|c|c|}
\hline \multirow{2}{*}{ IDADE } & \multicolumn{2}{|c|}{ COLONIÃO } & \multicolumn{2}{|c|}{ TOBIATÃ } & \multicolumn{2}{|c|}{$K-187 \mathrm{~B}$} \\
\hline & $\% \mathrm{~S}$ & $N: S$ & $\% s$ & $N: S$ & $\% s$ & $N: S$ \\
\hline 28 & 0,15 & 20 & 0,18 & 17 & 0,17 & 18 \\
\hline 56 & 0,12 & 23 & 0,15 & 16 & 0,15 & 15 \\
\hline 84 & 0,09 & 24 & $0,09 b$ & 23 & 0,15 & 14 \\
\hline 112 & 0,06 & 27 & $0,12 a$ & 16 & 0,12 & 15 \\
\hline 140 & 0,07 & 24 & 0,09 & 20 & 0,10 & 17 \\
\hline MÉOIA & $0,10 \mathrm{~b}$ & $24 a$ & $0,13 a$ & $18 \mathrm{~b}$ & $0,14 \mathrm{a}$ & $16 \mathrm{~b}$ \\
\hline
\end{tabular}

Médias seguidas de letras diferentes, diferem entre si pelo Teste de Tukey $(P<0,05)$.

Segundo National Research Council (1984), o qual rêlatou as exigências de gado de corte, o capim colonião teria teores de enxofre satisfatórios até a idade cie 56 dias. o tobiatã poderia suprir as necessidade do elemento para os bovinos até a idade de 112 dias, embora aos 84 dias o teor seja menor que $0,10 \%$. Já o K-187 B teria os requerimentos supridos em todas as idades estudadas.

Quanto às médias das relações nitrogênio:enxofre, obtidas para as lâminas foliares (Tabela 16), a análise de variância revelou que os capins diferiram entre si $(P<0,01)$. Comparando-se as médias, verificou-se que os capins tobiatã e K-187 B não diferiram e ambos apresentaram menores relações $\mathrm{N}: \mathrm{S}$ que o colonião.

Deve-se ressaltar que a relação nitrogênio : en- 
xofre adequada para a nutrição animal é ao redor de 14; porém, desde que os teores de enxofre não sejam deficientes, relações superiores não trazem qualquer inconveniente para alimentação animal. Nota-se pelo exposto que os valores dessa relação para os capins K-187 B e tobiatã parecem mais próximas da adequada para a nutrição animal. (Tabela 16 ).

A tabela 17 apresenta as médias dos teores de cobre e de ferro, das lâminas foliares dos capins estudados.

A análise de variância dos teores de cobre mostrou que os capins não diferiram entre si.

Tabela 17. Médias dos teores de cobre (ppm Cu) e de ferro (ppm Fe) das lâminas foliares dos capins estudados.

\begin{tabular}{|c|c|c|c|c|c|c|}
\hline \multirow{2}{*}{ IDADE } & \multicolumn{2}{|c|}{ COLONIÃO } & \multicolumn{2}{|c|}{ TOBIATÃ } & \multicolumn{2}{|c|}{$K-187 B$} \\
\hline & $\mathrm{ppm} \mathrm{Cu}$ & $\mathrm{ppm} F \mathrm{e}$ & $\mathrm{ppm} \mathrm{Cu}$ & $p p m F e$ & $\mathrm{ppm} \mathrm{Cu}$ & $p p m F e$ \\
\hline 28 & 9 & 784 & 10 & 1.040 & 10 & 713 \\
\hline 56 & 8 & 242 & 7 & 291 & 6 & 245 \\
\hline 84 & 5 & 223 & 5 & 223 & 6 & 296 \\
\hline 112 & 4 & 230 & 6 & 255 & 5 & 352 \\
\hline 140 & 4 & 323 & 4 & 218 & 4 & 218 \\
\hline MÉDIA & 6,0 & 361 & 6,4 & 412 & 6,1 & 365 \\
\hline
\end{tabular}

Os teores de cobre obtidos neste trabalho para as lâminas foliares dos capins são mais baixos do que os verificados por GOMIDE et alii (1979 a). Contudo, segundo as exigências sugeridas por Minsón et alii (1967), citados por 
WHITEMAN (1980), nas idades de 28, 56 e 84 dias, os capins atenderiam o requerimento de cobre para gado de corte.

Para as médias dos teores de ferro das lâminas foliares (Tabela 17), a análise de variância revelou que os capins não diferiram entre si.

Os teores de ferro das forrageiras estão muito - acima das exigências dos animais, Minson et alii (1967), citados por WHITEMAN (1980).

A Tabela 18 mostra as médias dos teores de manganês e de zinco das lâminas foliares dos capins estudados.

A análise de variância dos teores de manganês revelou que os capins não diferiram entre si.

Tabela 18. Médias dos teores de manganēs (ppm $M n$ ) e de zinco (ppm $\mathrm{Zn}$ ), das läminas foliares dos capins estudados.

\begin{tabular}{|r|c|c|c|c|c|c|}
\hline \multirow{3}{*}{ IDADE } & \multicolumn{2}{|c|}{ COLONIÃO } & \multicolumn{2}{c|}{ TOBIATA } & \multicolumn{2}{c|}{ K-187 B } \\
\cline { 2 - 7 } & $\mathrm{ppm} \mathrm{Mn}$ & $\mathrm{ppm} 2 n$ & $\mathrm{ppm} M n$ & $\mathrm{ppm} 2 n$ & $\mathrm{ppm} M n$ & $\mathrm{ppm} Z \mathrm{Zn}$ \\
\hline 28 & 261 & 34 & 207 & 26 & 221 & 28 \\
56 & 289 & 28 & 230 & 21 & 256 & 24 \\
84 & 232 & 32 & 193 & 16 & 241 & 21 \\
112 & 208 & 21 & 228 & 20 & 191 & 17 \\
140 & 256 & 19 & 213 & 19 & 226 & 17 \\
\hline MÉOIA & 249 & $27 \mathrm{a}$ & 214 & $21 \mathrm{~b}$ & 227 & $22 \mathrm{~b}$ \\
\hline
\end{tabular}

Médias seguidas de letras diferentes, diferem entre si pelo Teste de Tukey $(P<0,05)$.

Os teores de mànganès para as lâminas foliares obtidos neste trabalho são semelhantes aos observados por GOMIDE 
et alii (1979 a) para a planta inteira de colonião. Os teores de manganês das forragens estão muito acima das exigências dos bovinos.

Quanto às médias dos teores de zinco das lâminas foliares (Tabela 18), a análise de variância mostrou que os capins diferiram entre si $(\mathrm{P}<.0,01)$

Comparando-se as médias verífica-se que os capins tobiatã e K-187 B não diferiram e ambos tem teores de zin co menores que o colonião.

Os teores de zinco das lâminas foliares obtidos neste trabalho são mais elevados que os apresentados por GOMIDE et alii (1979 a), para a planta inteira de colonião.

o capim colonião poderia suprir a exigências de gado de corte até a idade de 112 dias, enquanto o capim K-187 B atenderiam o requerimento em zinco até a idade de 84 dias e o capim tobiatã somente até a idade de 56 dias.

4.2. Comparação através de equações de regressão dos capins frente as idades de corte estudadas.

4.2.1. Ganho acumulativo de matéria seca dos capins

Conforme já referido, o ganho acumulativo de matéria seca foi estudado sob três variáveis: produção de matéria seca total (MST), produção de matéria seca do material verde (MSV) e produção de matéria seca do material seco (MSS). A análise de variância para as três variáveis , 
mostrou que as produções nas idades de corte estudadas diferiram entre si $(P<0,01)$. Verificou-se também, através dessa análise, que a interação capim $x$ idade de corte não foi significativa para nenhuma dessas variáveis. Esses resultados mostram que os capins colonião, tobiatã e K-187 B tiveram o mesmo padrão de ganho acumulativo de matéria seca nas idades de corte estudadas, podendo-se, desta máneira, estimar a equação dos ganhos acumulativos de MST, MSV e MSS pelas médias dos très capins.

A Tabela 19 mostra as equações de regressão para os ganhos acumulativos de MST, MSV e MSS, e os valores de CV, $F$ e $R^{2}$, da análise estatistica.

A Figura l mostra as curvas que representam os padrões de ganho acumulativo de MST, MSV e MSS.

Verifica-se que o ganho acumulativo de MST pode ser representado por uma equação de regressão quadrática. curva que representa esta variável (Figura 1) não se assemelha a uma curva sigmóide, característica do desenvolvimento de seres biológicos. Nota-se que no início do crescimento falta o segmento da curva, inflexão positiva que caracteriza a fase inicial de crescimento mais lento. Essa imperfeição da curva foi também observada por ANDRADE e GOMIDE (1971) para o capim elefante. Esses autores sugeriram que a ausência da inflexão positiva da curva ocorreu em virtude do primeiro corte ter sido aos 28 dias de crescimento, época em que o capim já teria atingido um estádio de desenvolvimento mais intenso. 


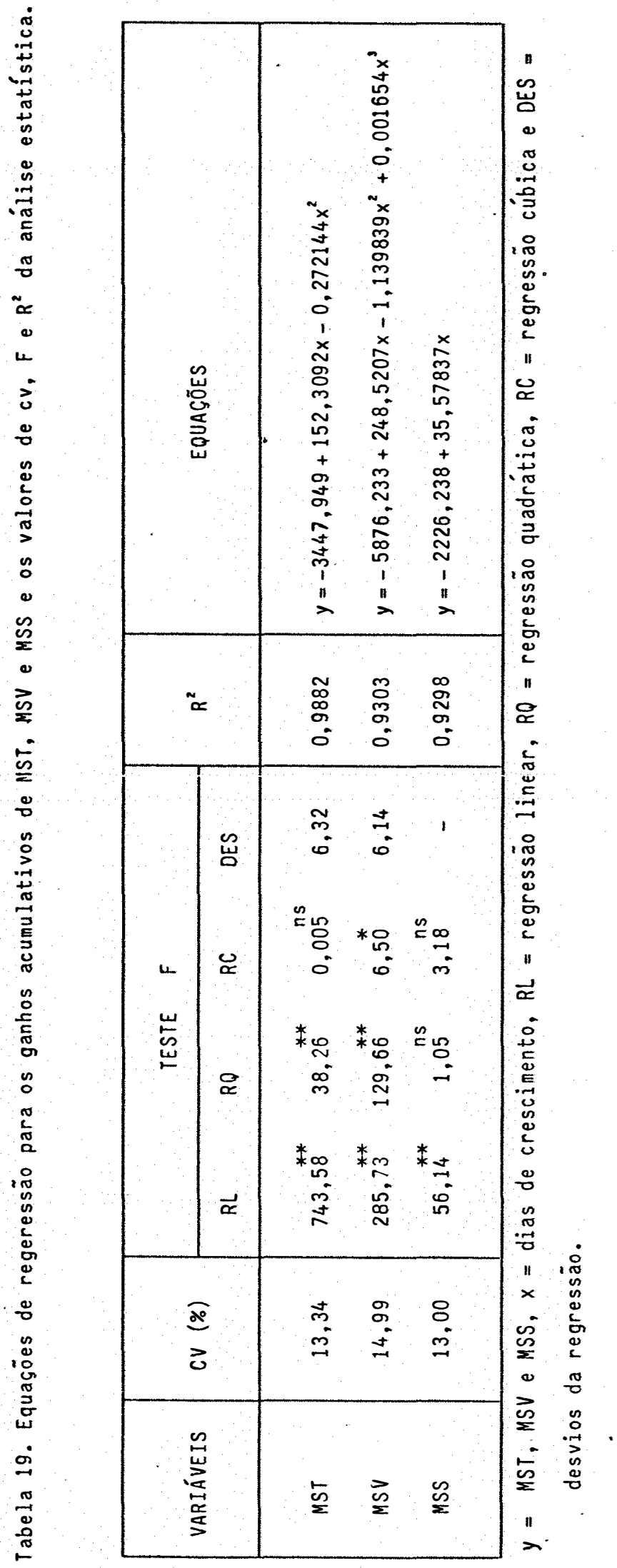




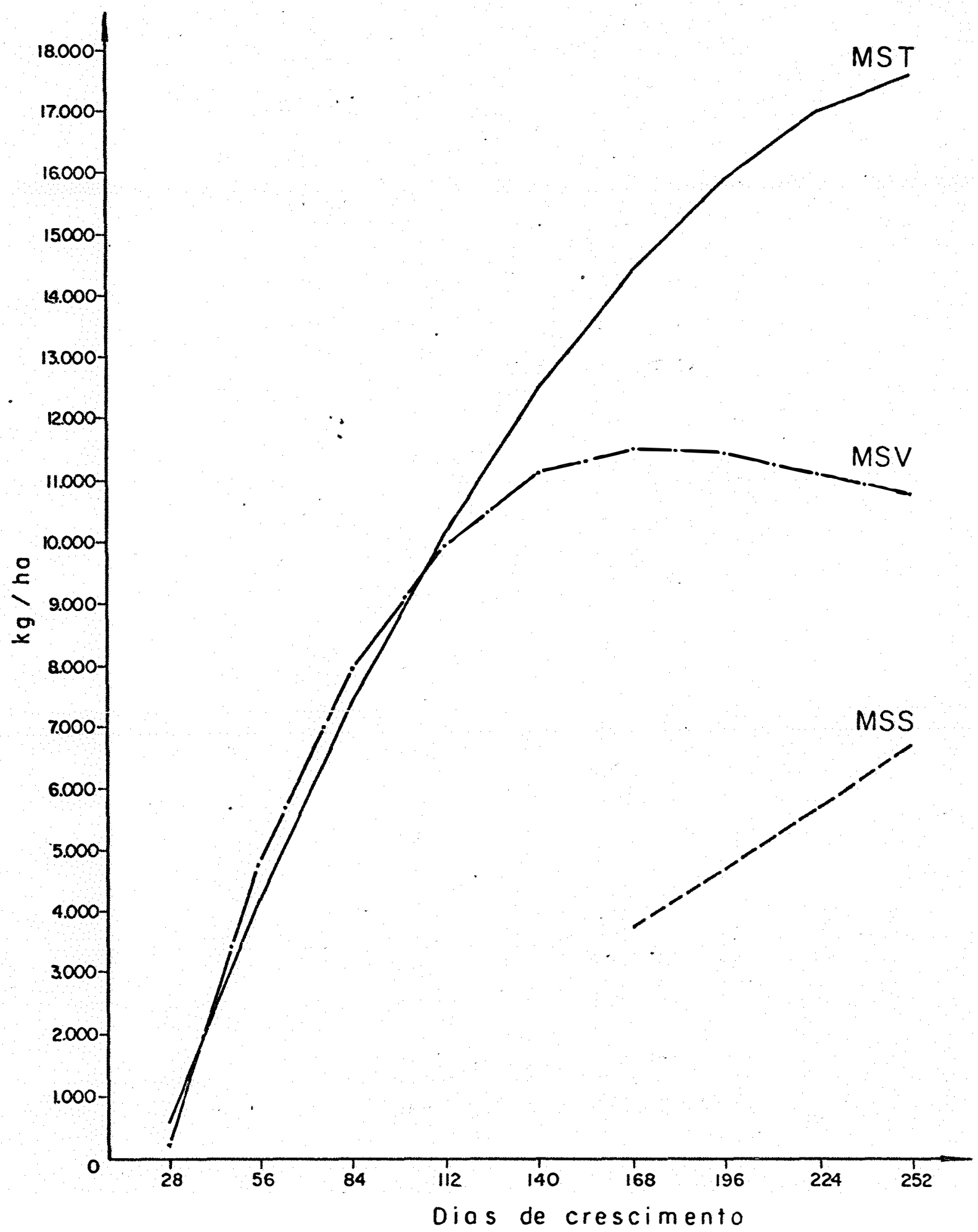

Figura 1-Curvos que representam os padröes de ganho acumulativo de matéria seca total (MST), matéria seca do material verde (MSV) e matéria seco do material seco (MSS). 
Por outro lado, pode-se observar que a curva que representa o ganho acumulativo de MST (Figura l) não atin giu o seu ponto máximo. No entanto, isto já era esperado, uma vez que esse ganho acumulativo foi estimado somando-se a matéria seca proveniente do material verde à matéria seca do material seco, o que resultou num crescente acúmulo de matéria seca. Numa duração mais prolongada destas amostragens o ponto de máximo seria atingido.

A equação de regressão para o ganho acumulativo de MSV é cúbica (Tabela 19). A curva que a representa, (Figura 1) já se aproxima mais de um traçado sigmóide. Nota-se que o ponto de máxima produção foi alcançado ao redor de 168 dias de crescimento. Isto teria ocorrido precocemente, em razão do período de baixa pluviosidade e do ataque de nematóides, já referidos. Todavia, excetuando-se a ausência da inflexão positiva do início da curva, o traçado da curva que representa o ganho acumulativo de MSV é semelhante à curva sigmóide econtra da por BARNES (1960), BROUGHAM (1965), PEDREIRA $(1965 / 66)$ e PEDREIRA E BOIN (1969).

o ganho acumulativo de MSS, medido a partir da idade de 168 dias, pode ser representado por uma regressão linear (Tabela 19). Essa equação apresenta $b=35,578370$, que representa o ganho diário de MSS. Desta maneira, pode-se dizer que a partir da idade de 168 dias houve uma perda diária de $35,58 \mathrm{~kg} / \mathrm{ha}$ de matéria seca do material verde. 
4.2.2. Número de perfilhos por área, peso médio dos perfilhos, relação lâmina:haste, altura da cultura, altura do meristema apical e vigor de rebrota

A análise de variância mostrou que o número de perfilhos diferiu nas diversas idades de corte estudadas, $(P<0,01)$. A interação capim $x$ idade de corte foi significativa $(P<0,01)$. Esses resultados mostram que cada capim tem um padrão distinto de variação do número de perfilhos com as idades de corte.

A Tabela 20 mostra as equações de regressão pa ra o número de perfilhos por área, peso médio dos perfilhos e os valores de $\mathrm{cV}, \mathrm{F}$ e $\mathrm{R}^{2}$ da análise estatística.

As curvas que representam os padrões de varia ção do número de perfilhos por área e do peso médio dos perfilhos são mostradas na Figura 2.

No presente trabalho, a variação do número de perfilhos verificada com as idades de corte é semelhante à observada por PEDREIRA e BOIN (1969) para o capim elefante na pier.

A análise de variância mostrou que o peso médio de perfilhos diferiu nas diversas idades de corte estudadas $(P<0,01)$. A interação capim $x$ idade de corte não foi significativa. Por esses resultados pode-se concluir que os capins colonião, tobiatã e K-187 B. apresentaram o mesmo pa- 


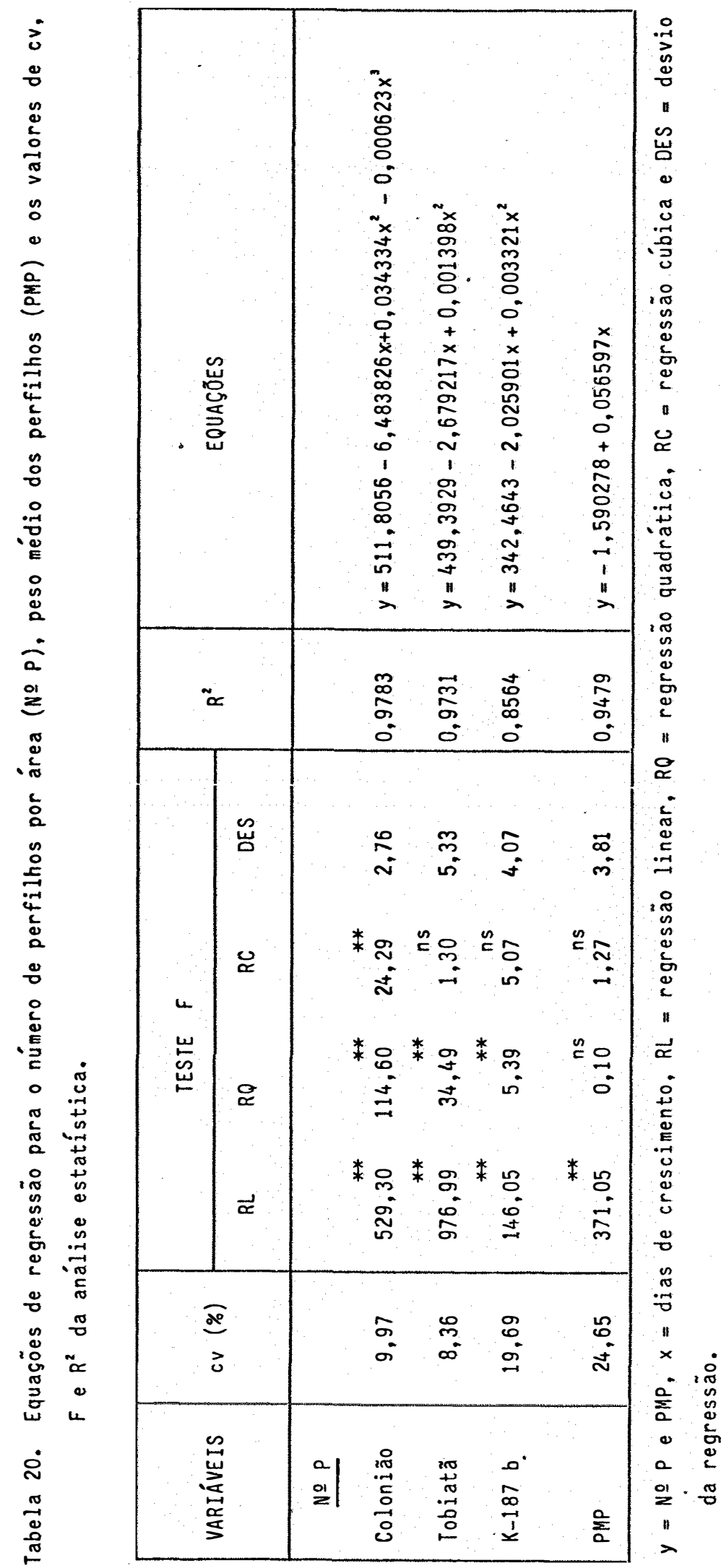




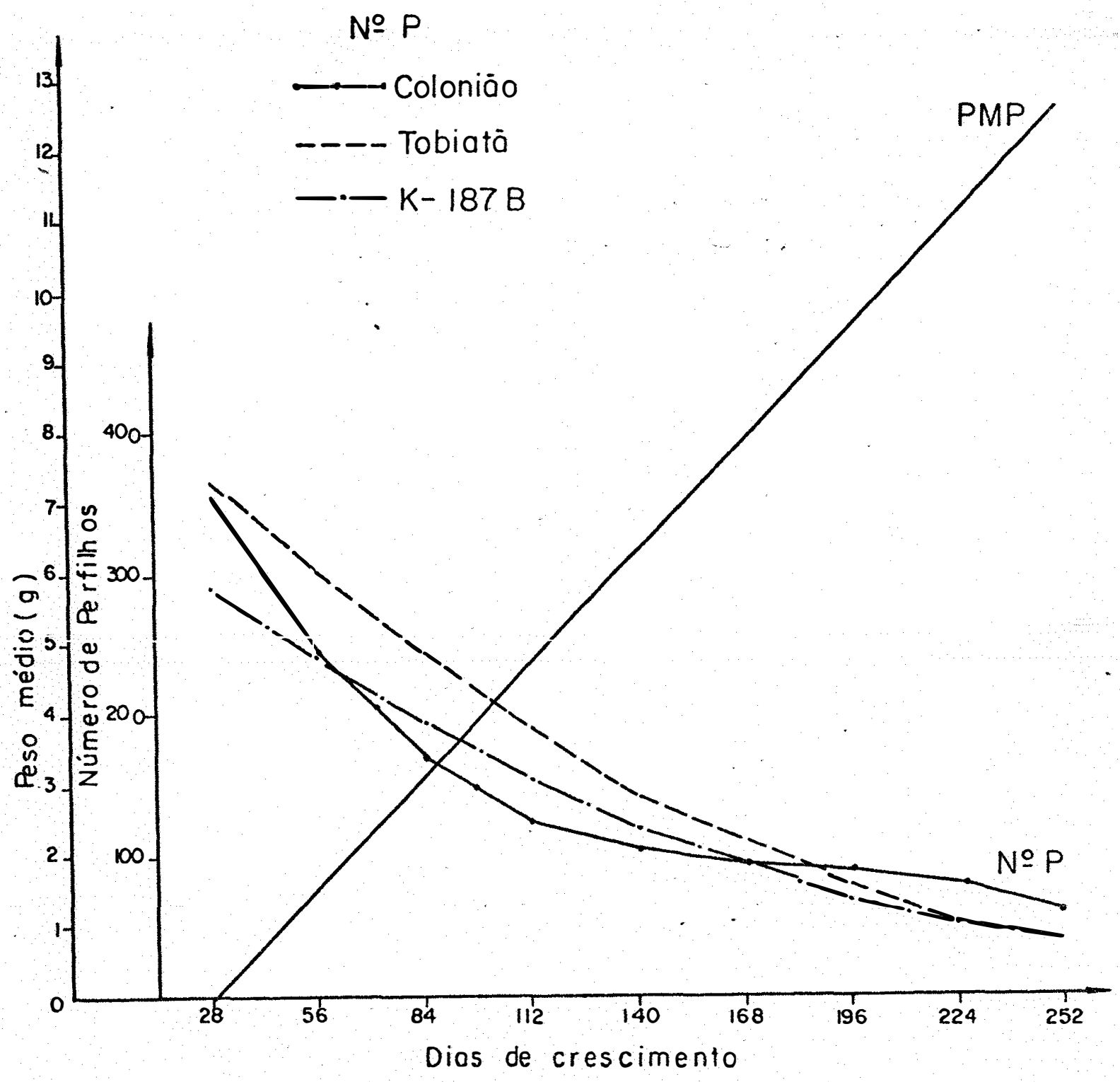

Figura 2-Curvas que representam os padrōes de variaçāo do número de perfilhos $/ 0,5 \mathrm{~m}^{2}$ ( $N$ ㅇ $P$ ) e o peso médio dos perfilhos ( $P M P$ ) em $\mathrm{g}$ de motério seca. 
drão de variação para o peso médio dos perfilhos, o qual pode ser representado por uma única equação de regressão. (Tabela 20 e Figura 2).

Os resultados para número de perfilhos por área e para peso médio dos perfilhos (Figura 2) e os ganhos acumula tivos de matéria seca (Figura 1), vem mais uma vez confirmar que os maiores rendimentos de forrageiras ém crescimento contínuo estão associados ao peso individual de perfilhos e não ao maior número destes.

A análise de variância mostrou que as relações lâmina:haste diferiram nas diversas idades de corte estudadas $(P<0,01)$. A interação capim $x$ idade de corte não foi signifí cativa. Esses resultados mostram que os capins colonião, tobia tã e K-187 B apresentaram o mesmo padrão de variação para rela ção lâmina:haste com as idades de corte, padrão esse que pode ser representado por uma única equação de regressão.

A Tabela 21 mostra as equações de regressão para a relação lâmina:haste, altura da cultura, altura do meristema apical e.vigor de rebrota, e os valores de $c v, F$ e $R^{2}$ da análise estatística.

A figura 3 mostra as curvas que representam os padrões de variação da relação lâmina:haste, altura da cultura, altura do meristema apical e vigor de rebrota.

A queda da relação Iâmina:haste com a idade da planta observada neste trabalho é semelhante a verificada por PEDREIRA $(1965 / 66)$. 


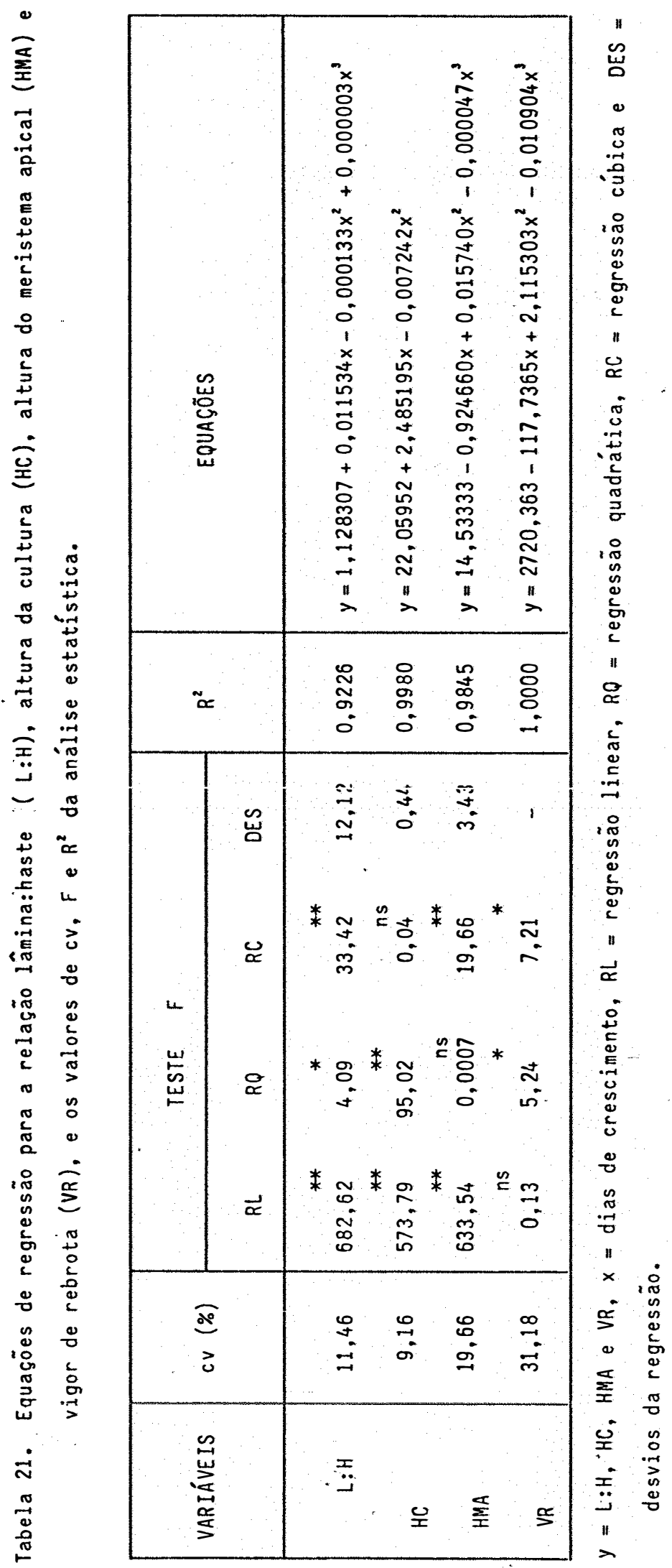




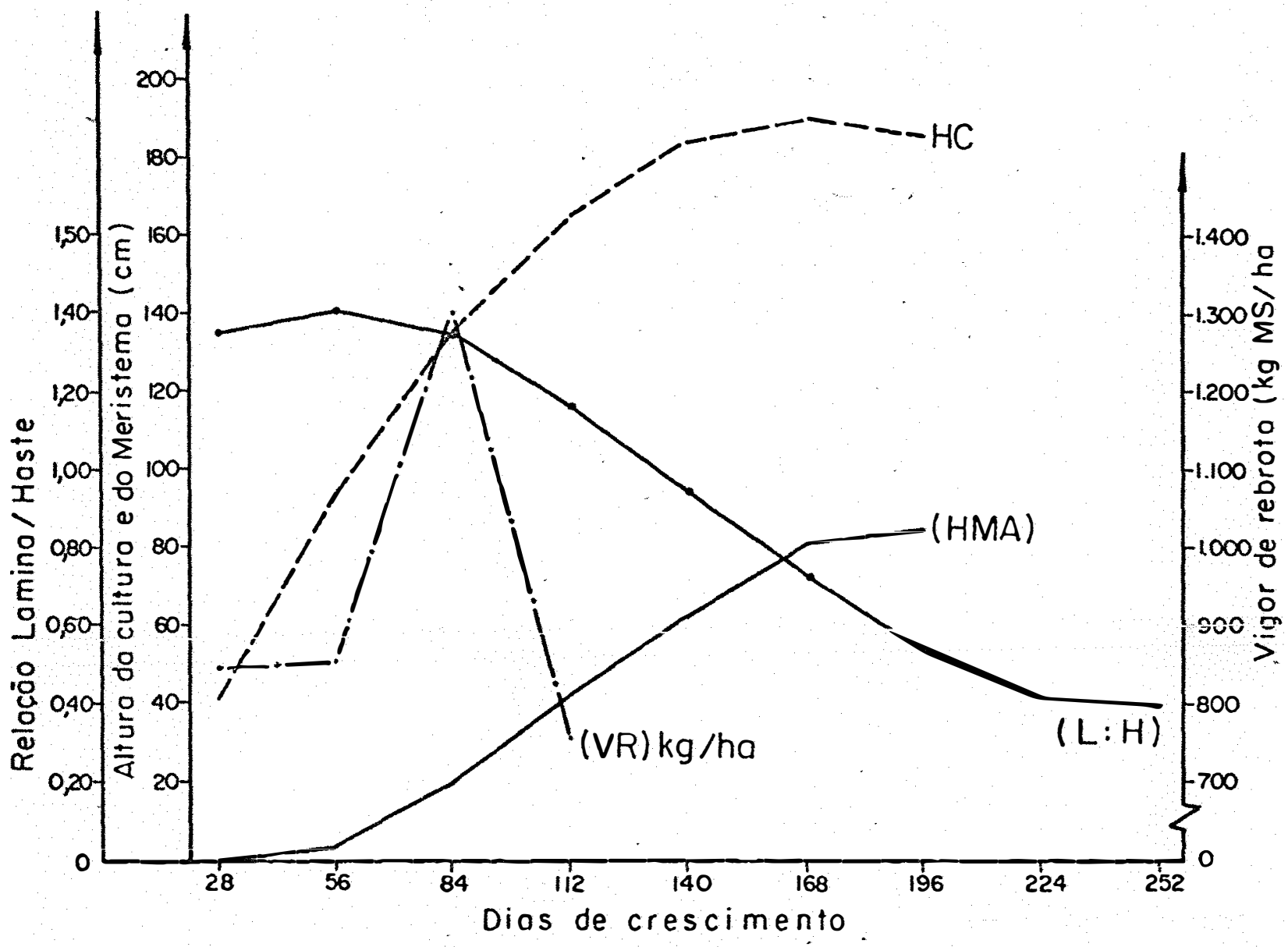

Figura 3-Curvas que representam os padrōes de variaçào da relaçāo lômina: haste $(L: H)$, em matério seca, altura do cultura (HC) em $\mathrm{cm}$, altura do meristema apical (HMA) em $\mathrm{cm}, e$ vigor de rebroto (VR) em $\mathrm{kg} \mathrm{MS/ha.}$ 
A análise de variância mostrou que as alturas da cultura diferiram nas diversas idades de corte estudadas $(P<0,01)$. A interação capim $x$ idade de corte não foi signifi cativa. Pode-se concluir que os capins colonião, tobiatã e K-187 B apresentaram o mesmo padrão de variação para altura da cultura podendo esta ser representada por uma única equação de regressão (Tabela 21 ).

A análise de variância mostrou que as alturas do meristema apical diferiram nas diversas idades de corte estudadas $(P<0,01)$. A interação capim $x$ idade não foi significativa. Esses resultados permitem concluir que os capins colonião, tobiatã e K-187 B apresentaram o mesmo padrão de variaçäo para altura do meristema apical, podendo este ser represen tado por uma única equação de regressão (Tabela 2l).

Os resultados obtidos para altura do meristema apical são diferentes dos de GOMIDE et alii (1979 b) e NASCIMENTO et alii (1980).

A análise de variância mostrou que o vigor de rebrota variou significativamente com as diversas idades de corte estudadas $(P<0,05)$. A interação capim $x$ idade de corte não foi significativa. Esses resultados mostram que os capins colonião, tobiatã e K-187 B apresentaram o mesmo padrão de variação para o vigor de rebrota, podendo este ser representado por uma única equação de regressão (Tabela 21).

Os resultados obtidos para vigor de rebrota nes te trabalho não estão de acordo com os de GOMIDE et alii (1979 b) 
GOMIDE e ZAGO (1980) e BOTREL et alii (1981), os quais encontraram alta correlação entre o vigor de rebrota e a decapitação de perfilhos. O que pode ter ocorrido neste trabalho é que embora a altura de corte tenha sido feita a $10 \mathrm{~cm}$ da superficie do solo, provavelmente não tenha ocorrido uma grande decapitação de perfilhos na idade de 84 dias, pois, a posição oblí qua dos perfilhos de capim colonião faz com que haja uma redução efetiva do ápice meristemático, o que o protegeria do corte. Para os outros capins, mesmo uma pequena inclinação dos perfilhos já teria esse mesmo efeito, uma vez que a altura do meristemático apical nesses capins corresponderia praticamente à altura de corte.

4.2.3. Teores de matéria seca, fibra bruta e proteína bruta, e participação porcentual de proteína bruta da lâmina e da haste em relação à planta inteira

A análise de variância mostrou que os teores de matéria seca diferiram nas diversas idades de corte estudadas $(P<0,01)$. A interação capim $x$ idade de corte não foi significativa. Esses resultados mostram que os capins colonião, tobiatã e K-187 B apresentaram o mesmo padrão de variação dos teores de matéria seca com as idades de corte, facultando a sua representação por uma única equação de regressão.

A Tabela 22 mostra as équações de regressão pa ra os teores de matéria seca e de fibra bruta, e os valores 
de $c v, F$ e $\mathrm{R}^{2}$ da análise estatística.

A Figura 4 mostra as curvas que representam os padrổes de variação dos teores de matéria seca e da fibra bruta.

A variação do teor de matéria seca com as idades de corte observada neste trabalho é semelhante à verificada por PEDREIRA (1965/66) para o capim colonião e por GOMIDE et alii (1969 a) para outros 6 capins tropicais.

A análise de variância mostrou que os teores de fibra bruta diferiram nas diversas idades de corte estudadas $(P<0,01)$. A interação capim $x$ idade de corte foi signifi cativa $(P<0,01)$. Pociendo-se concluir que cada capim apresentou um padrão de variação distinto para os teores de fibra bru ta com as idades de corte (Tabela 22 e Figura 4).

A variação dos teores de fibra bruta com as ida des de corte verificada neste trabalho é semelhante à observada para o capim colonião por PEDREIRA e SILVEIRA (1972) e para outros 6 capins tropicais por GOMIDE et alii (1969 a).

A análise de variāncia mostrou que os teores de proteína bruta da planta inteira diferiram nas diversas ida des de corte estudadas $(P<0,01)$. A interação capim $x$ idade de corte não foi significativa. Pode-se concluir que os capins colonião, tobiatã e K-187 B apresentaram o mesmo padrão de variação dos teores de proteína bruta da planta inteira com as idades de corte, permitindo a sua representação por uma única 


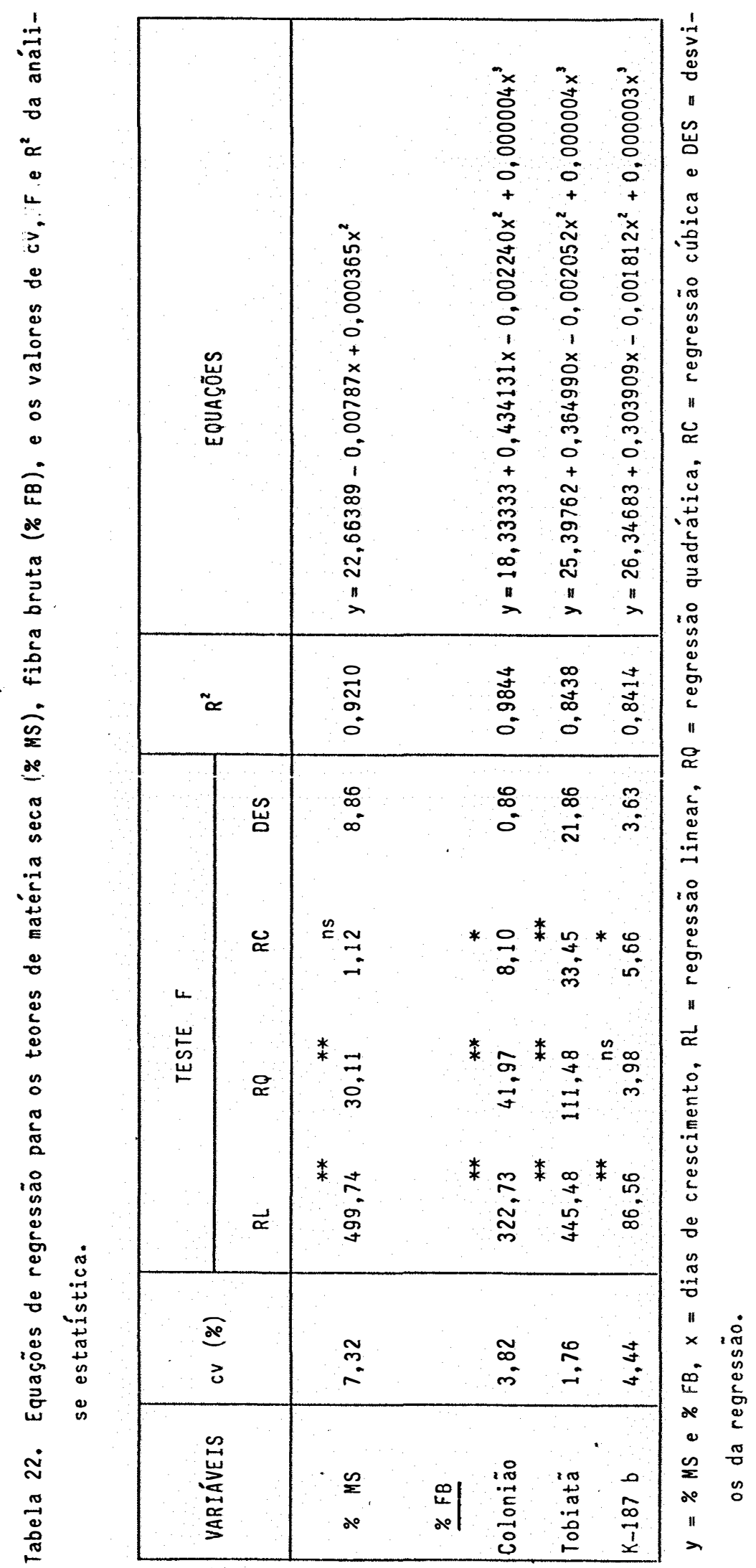




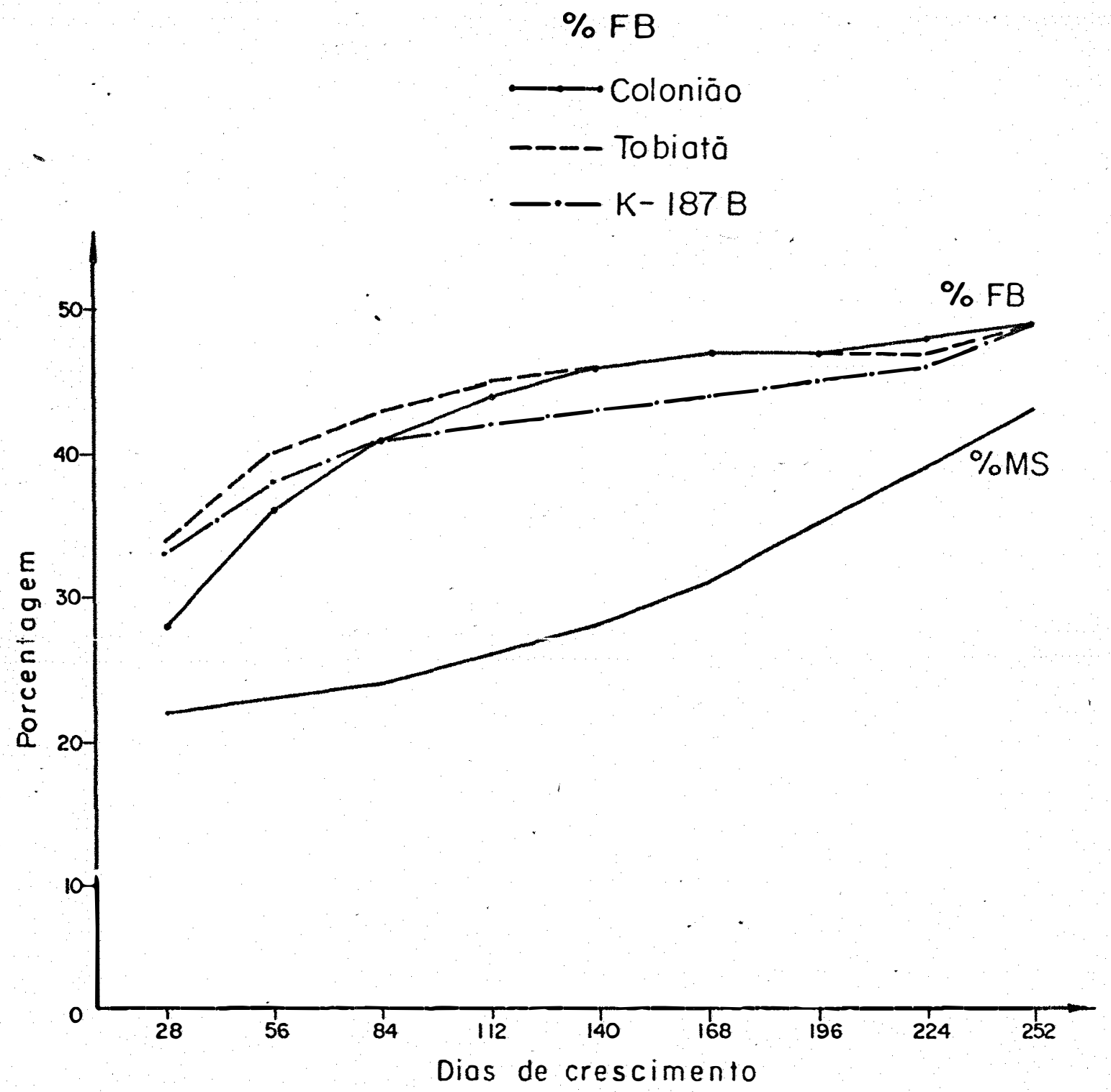

Figuro 4-Curvos que representom os padrōes de variacāo dos teores de matério seca (\%MS) e fibro bruto (\%FB). 
equação de regressão.

A Tabela 23 mostra as equações de regressão para os teores de proteína bruta da planta inteira, da lámina fo liar, da haste e das participações porcentuais de proteína bru ta da lâmina e da haste em relação à planta inteira, e os valores de $\mathrm{CV}, \mathrm{F}$ e $\mathrm{R}^{2}$ da análise estatística.

A Figura 5 mostra as curvas que representam os padrões de variação dos teores de proteína bruta da planta inteira, da lâmina foliar, da haste e das participações porcentuais de proteína bruta da lámina e da haste em relação à plan ta inteira.

A variação dos teores de proteína bruta da plan ta inteira com as idades de corte observada neste trabalho é semelhante a verificada por PEDREIRA e SILVEIRA (1972) para o capim colonião.

A análise devariância mostrou que os teores de proteína bruta da lâmina foliar diferiram nas diversas idades de corte estudadas $(P<0,01)$. A interação capim $\mathrm{x}$ idades de corte não foi significativa, o que permite concluir que os capins colonião, tobiatã e K-187 B apresentaram o mesmo padrão de variação de teores de proteína bruta da lâmina foliar com as idades de corte, podendo este ser representado por uma úni ca equação de regressão (Tabela 23 ) .

A variação dos teores de proteína bruta da lâmi na foliar encontrada neste trabalho é semelhante à observada por PEDREIRA e SILVEIRA (1972) para lâmina foliar do capim co- 
lonião.

A análise de variância mostrou que os teores de proteína bruta da haste diferiram nas diversas idades de corte estudadas $(P<0,01)$. A interação capim $x$ idade de corte não foi significativa, evidenciando que os capins colonião, tobiatã e K-187 B apresentaram o mesmo padrão de variação dos teores de proteina bruta da haste com as idades de corte, podendo este ser representados por uma única equação de regressão. (Tâ bela 23 ).

A variação dos teores de proteína bruta da haste com as idades de corte observadas neste trabalho é semelhan te à verificada por PEDREIRA e SILVEIRA (1972) para a haste do cañim colonião.

A análise de variância mostrou que as participações porcentuais de proteína bruta da lâmina e da haste diferiram nas diversas idades de corte estudadas $(P<0,01)$. A interação capim $x$ idade de corte não foi significativa para nenhuma dessas variáveis, o que serve para mostrar que os capins colonião, tobiatã e K-187 B apresentaram o mesmo padrão de variação para as participações porcentuais de proteína bruta da lãmina e da haste em relação à planta inteira com as ida des de corte. Cada um desses padrões de variação podem ser representados por uma única equação de regressão (Tabela 23). 


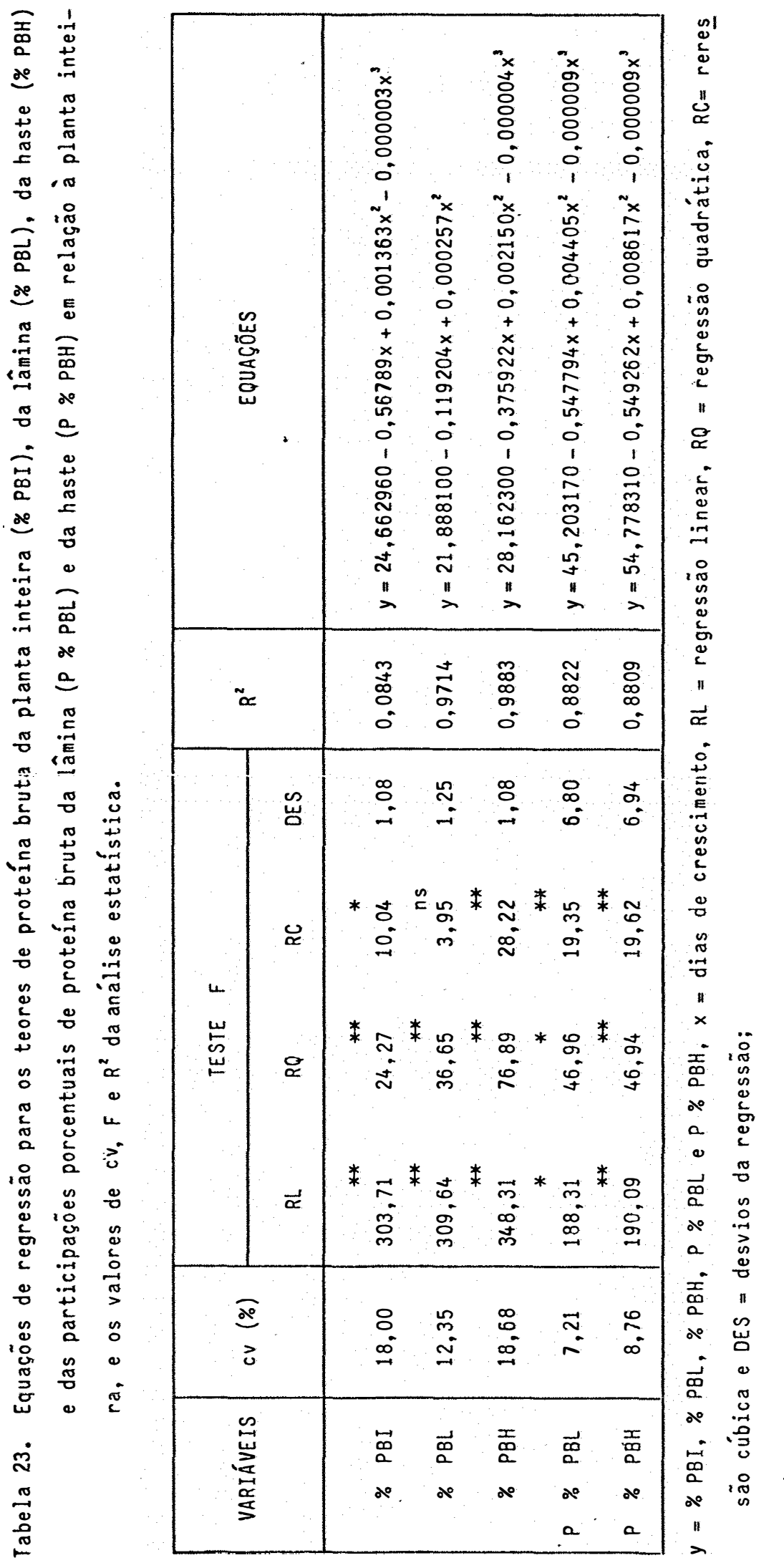




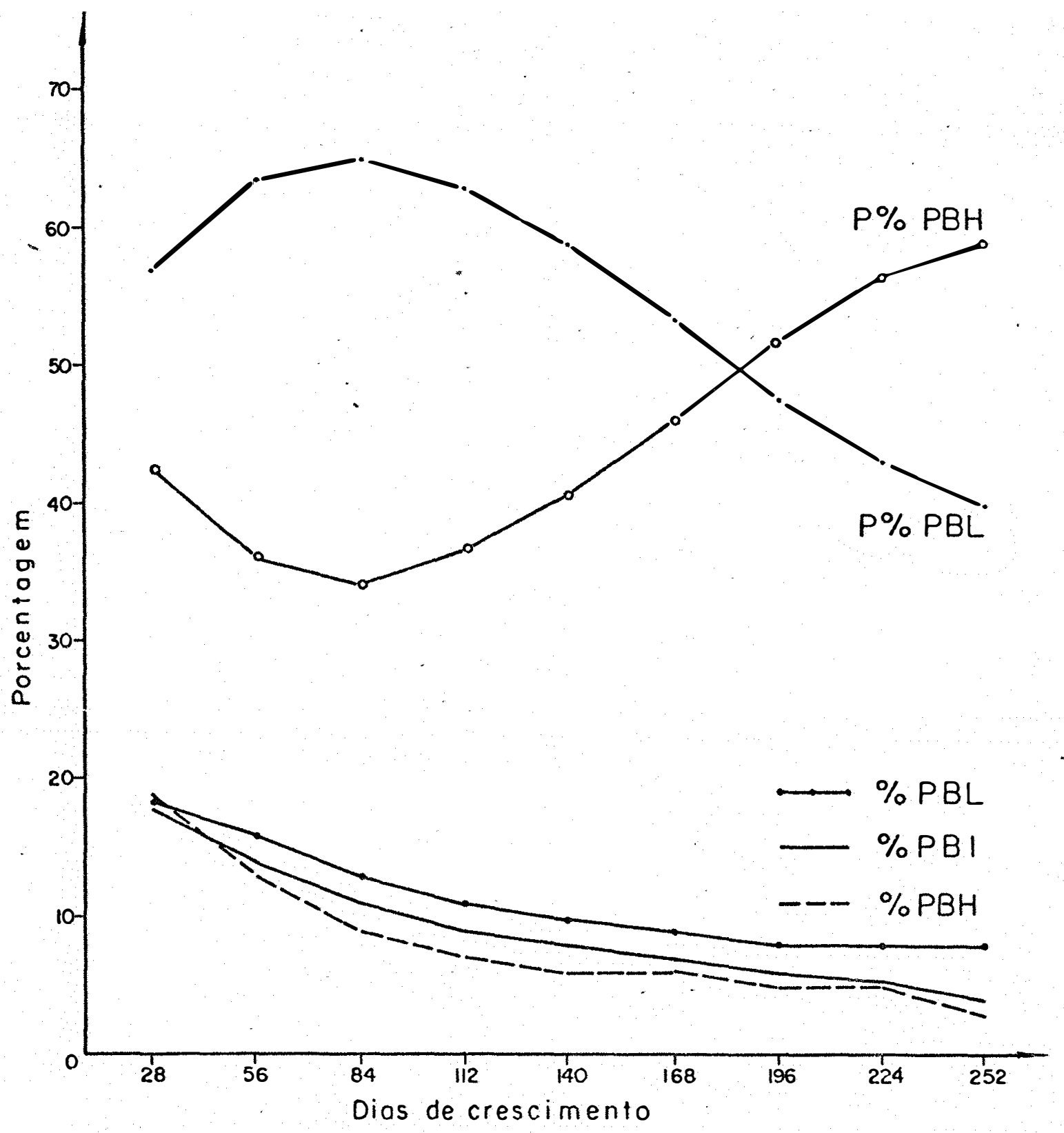

Figura 5-Curvas que representam os padrōes de variaçăo dos teores de proteína bruta da planta inteira (\%PBI), da lâmina(\%PBL), do haste (\% PBH) e dos participaçōes porcentuais de proteina bruta da lâmina $(P \% P B L)$ e da haste $(P \% P B H)$ em reloçào a planta inteira. 
4.2.4. Teores de conteúdo celular, fibra insolúvel em detergente neutro, fibra insolúvel em detergente ácido, hemicelulose, celulose, lignina e digestibilidade "in vitro" da matéria seca

A análise de variância mostrou que os teores de conteúdo celular diferiram nas diversas idades de corte estudadas $(P<0,01)$. A interação capim $x$ idade de corte não foi significativa sugerindo que os capins colonião, tobiatã e $\mathrm{K}-$ 187 B apresentaram o mesmo padrão de variação dos teores de conteúdo celular com as idades de corte. Isto permite que este padrão de variação possa ser representado por uma única equação de regressão.

A Tabela 24 mostra as equações de regressão pàra os teores de conteúdo celular, fibra insolúvel em detergente neutro e fibra insolúvel em detergente ácido e os valores de $C v, F$ e $R^{2}$ da análise estatistica.

A Figura 6 mostra as curvas que representam os padrões de variação dos teores de conteúdo celular, fibra insolúvel em detergente neutro e fibra insolúvel em detergente ácido.

A variação dos teores de conteúdo celular com as idades de corte observada neste trabalho é semelhante à verificada por ANDRADE (1973) para o capim colonião.

A análise de variância mostrou que os teores de fibra insolúvel em detergente neutro diferiram nas diversas 


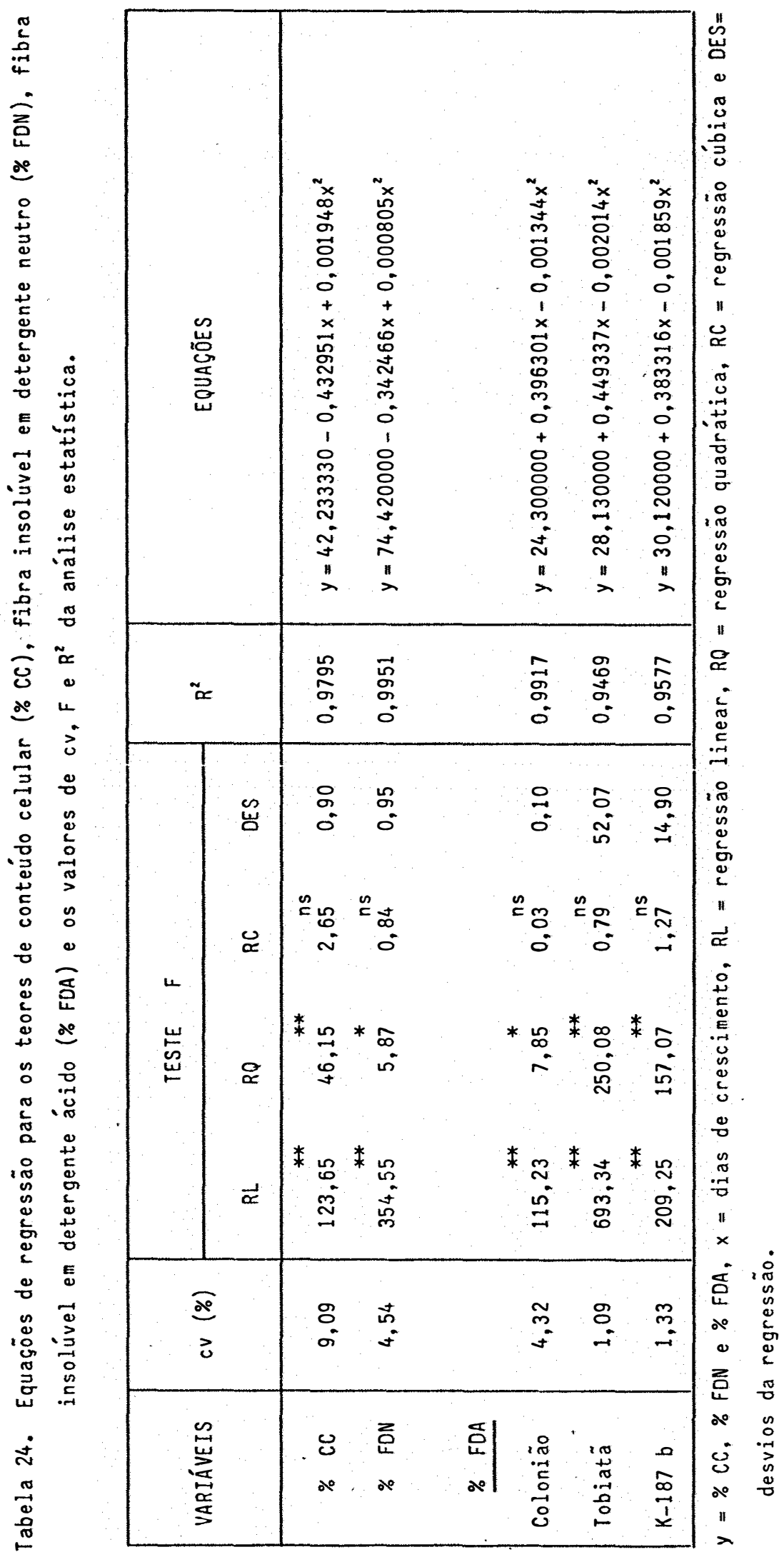




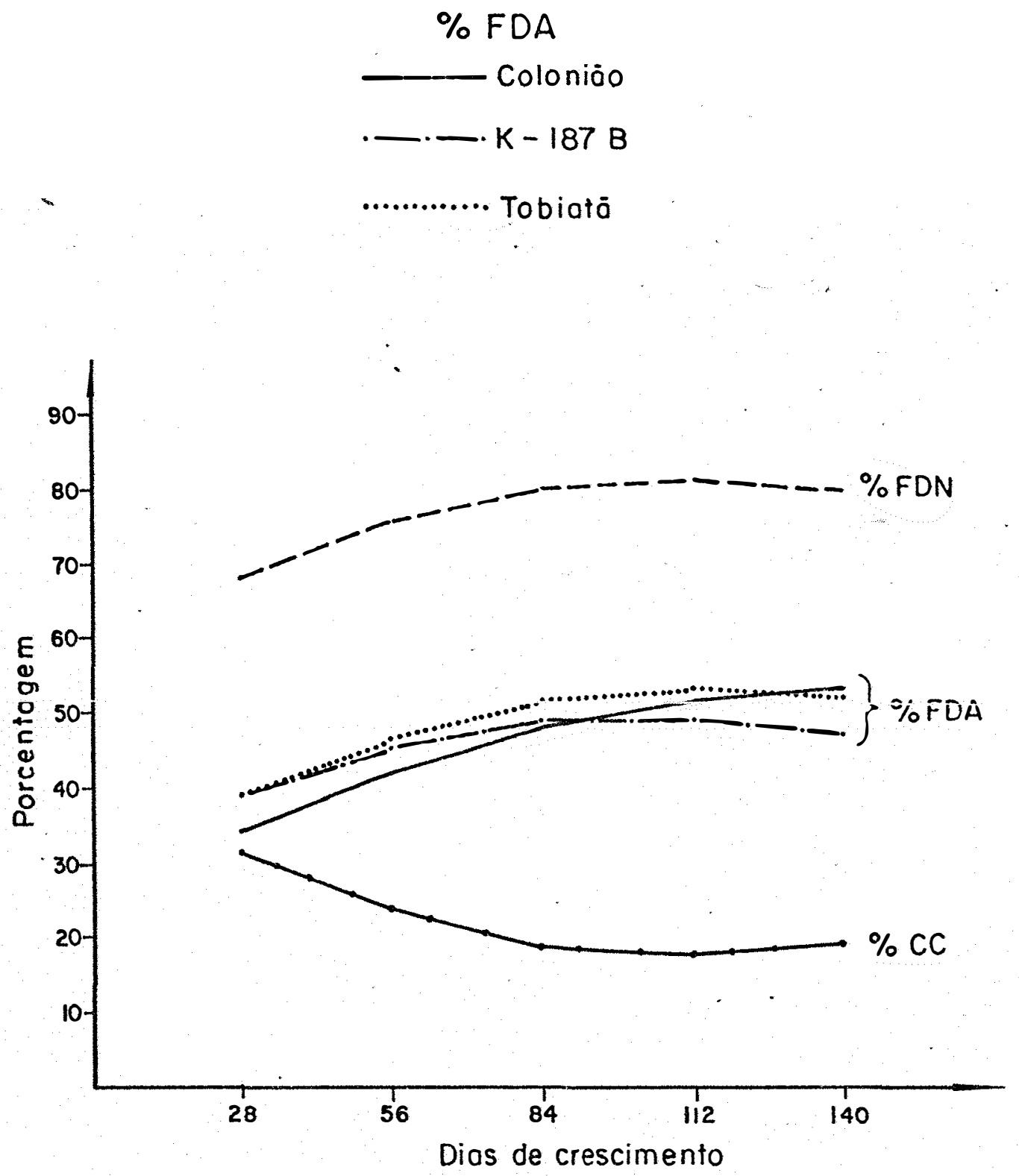

Figura 6-Curvos que representam os padrōes de variaçāo dos teores de conteudo celular (\%CC), fibra insolúvel em detergente neutro (\% FDN) e fibra insoluvel em detergente ácido (\% FDA). 
idades de corte estudadas $(P<0,01)$. A interação capim $x$ idade de corte não foi significativa. Esses resultados permitem concluir que os capins colonião, tobiatã e K-187 B apresentaram o mesmo padrão de variação dos teores de fibra insolúvel em detergente neutro com as idades de corte e que este é representado por uma única equação de regressão (Tabela 24).

A variação dos teores de fibra insolúvel em detergente neutro com as idades de corte observada neste trabalho é semelhante à verificada por ANDRADE (1973) para o capim colonião.

A análise de variância mostrou que os teores de fibra insolúvel em detergente ácido diferiram nas diversas idades de corte estudadas $(P<0,01)$. A interaçăo capim $x$ idade de corte foi significativa $(P<0,01)$. Pode-se concluir que cada capim apresentou um padrão de variação distinto para os teores de fibra insolúvel em detergente ácido com as idades de corte (Tabela 24 e Figura 6).

A variação dos teores de fibra insolúvel em detergente ácido com as idades de corte observada neste trabalho é semelhante à obtida por ANDRADE (1973) para o capim colonião.

A Tabela 25 mostra as equações de regressão para os teores de hemicelulose, celulose e lignina, e os valores de Cv, $F$ e $R^{2}$ da análise estatística.

A Figura 7 mostra as curvas que representam os padrões de variação dos teores de hemicelulose, celulose e lignina. 


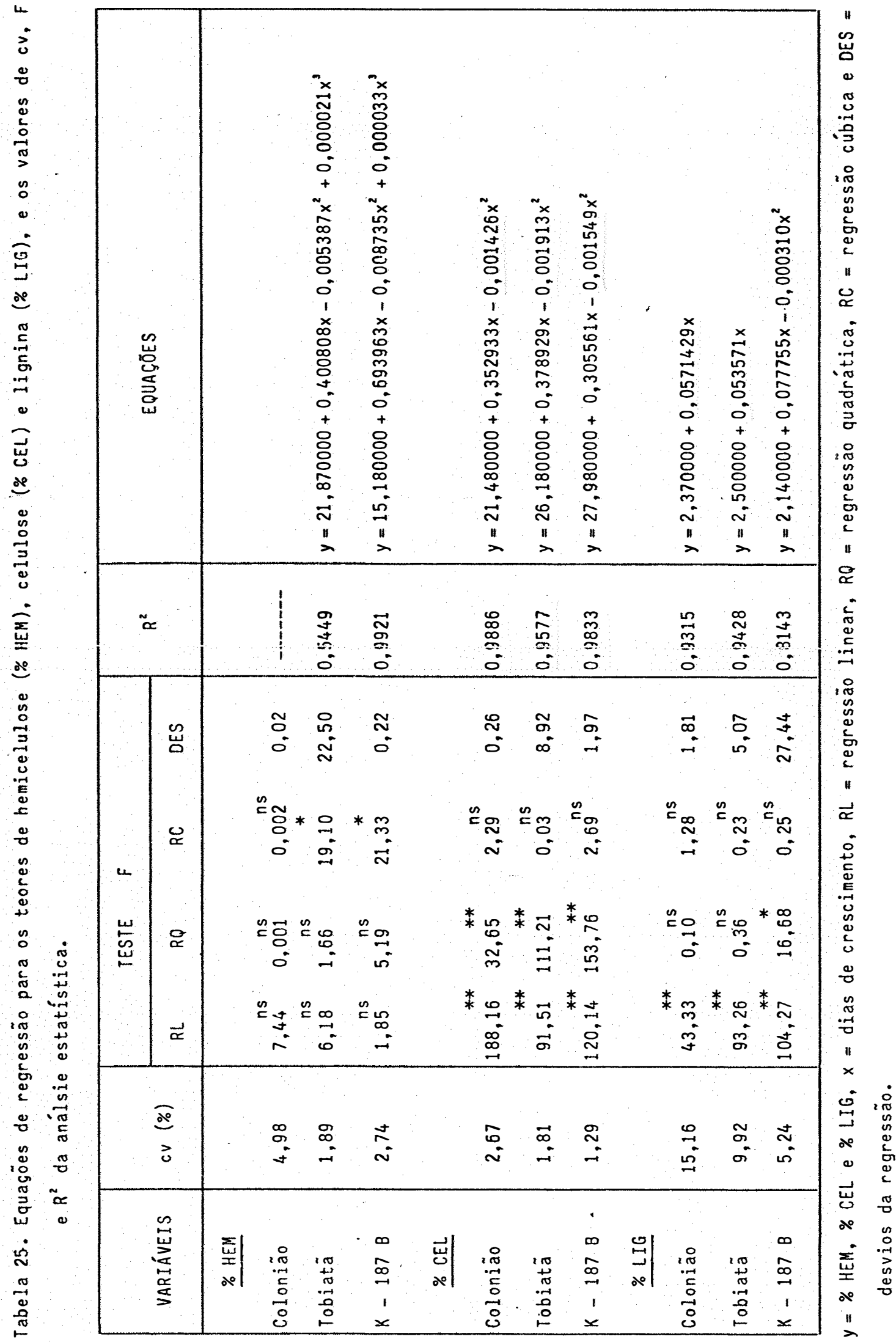




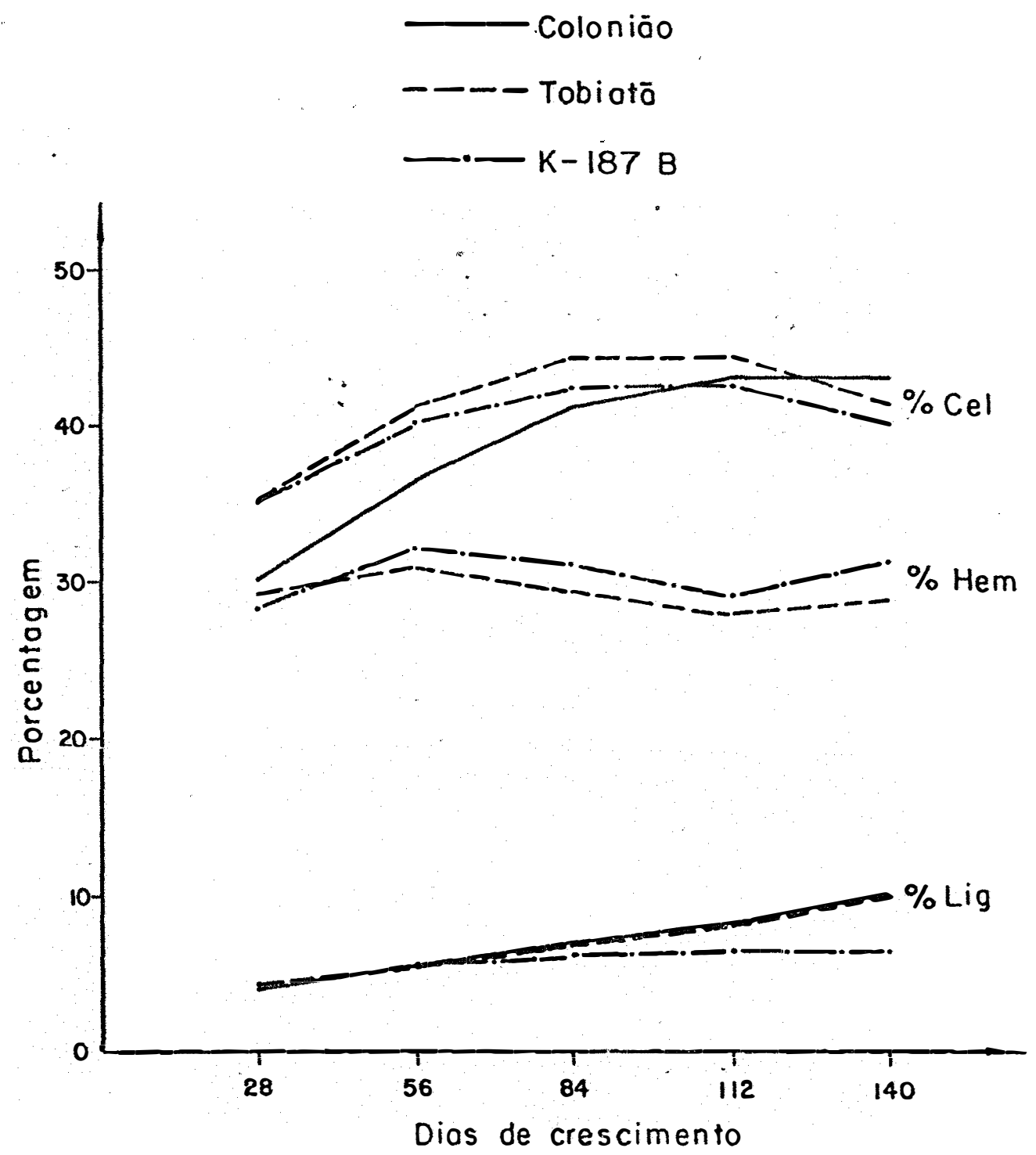

Figura 7-Curvas que representam os padrōes de variação dos teores de hemicelulose $(\% \mathrm{Hem})$, celulose $(\% \mathrm{Cel})$ e lignina (\% Lig). 
A análise de variāncia mostrou que os teores de hemicelulose diferiram nas diversas idades de corte estudadas $(P<0,01)$. A interação capim $x$ idade de corte foi significativa $(\mathrm{P}<0,05)$, o que permite concluir que cada capim apresentou um padrão de variação distinto para os teores de hemice lulose com as idades de corte. Todavia cabe ressaltar que a análise de variância para regressão dos teores de hemicelulose do capim colonião não apresentou significância para nenhuma das regressões propostas.

A variação dos teores de hemicelulose com as idades de corte verificada neste trabalho é semelhante à obser vada por ANDRADE (1973) para o capim colonião.

A análise de variạnria mostrou que os teores de celulose diferiram nas diversas idades de corte estudadàs $(P<0,01)$. A interação capim $x$ idade de corte foi significativa $(P<0,01)$ mostrando que cada capim apresentou um padrão de variação distinto para os teores de celulose com as idades de corte (Tabela 25 e Figura 7 ).

A variação dos teores de celulose com as idades de corte apresentada neste trabalho é semelhante à observada por ANDRADE (1973) para o capim colonião.

A análise de variāncia mostrou que os teores de lignina diferiram nas diversas idades de corte estudadas $(\mathrm{P}<0,01)$. A interação capim $\mathrm{x}$ idade de corte foi significati va $(P<0,01)$. Esses resultados mostram que cada capim apresentou um padrão de variação distinto para os teores de ligni- 
na com as idades de corte (Tabela 25 e Figura 7).

A variação dos teores de lignina com as idades de corte observadas neste trabalho é semelhante à verificada por ANDRADE (1973) para o capim colonião.

A análise de variância mostrou que as porcentagens de digestibilidade "in vitro" da matẹria seca diferiram nas diversas idades de corte estudadas $(P<0,01)$. A interação capim $x$ idades de corte foi significativa $(P<0,05)$ mostrando que cada capim apresentou um padrão de variação distinto para porcentagens de digestibilidade "in vitro" da matéria seca, com as idades de corte.

A Tabela 26 mostra as equações de regressão para a porcentagem de digestibilidade "in vitro" da matèria seca e os valores de cv, $F$ e $\mathrm{R}^{2}$ da análise estatística.

A Figura 8 mostra as curvas que representam os padrões de variação da porcentagem de digestibilidade "in vitro" da matéria seca.

A variação das porcentagens de digestibilidade "in vitro" da matéria seca com as idades de corte observada nes te trabalho é semelhante à verificada por GOMIDE et alii (1979 a).

\subsubsection{Teores de minerais}

A análise de variância mostrou que os teores de fósforo da lâmina foliar diferiram nas diversas idades de corte estudadas $(P<0,01)$. A interação capim $x$ idades de corte não foi significativa, sugerindo que os capins colonião, tobiatã e 


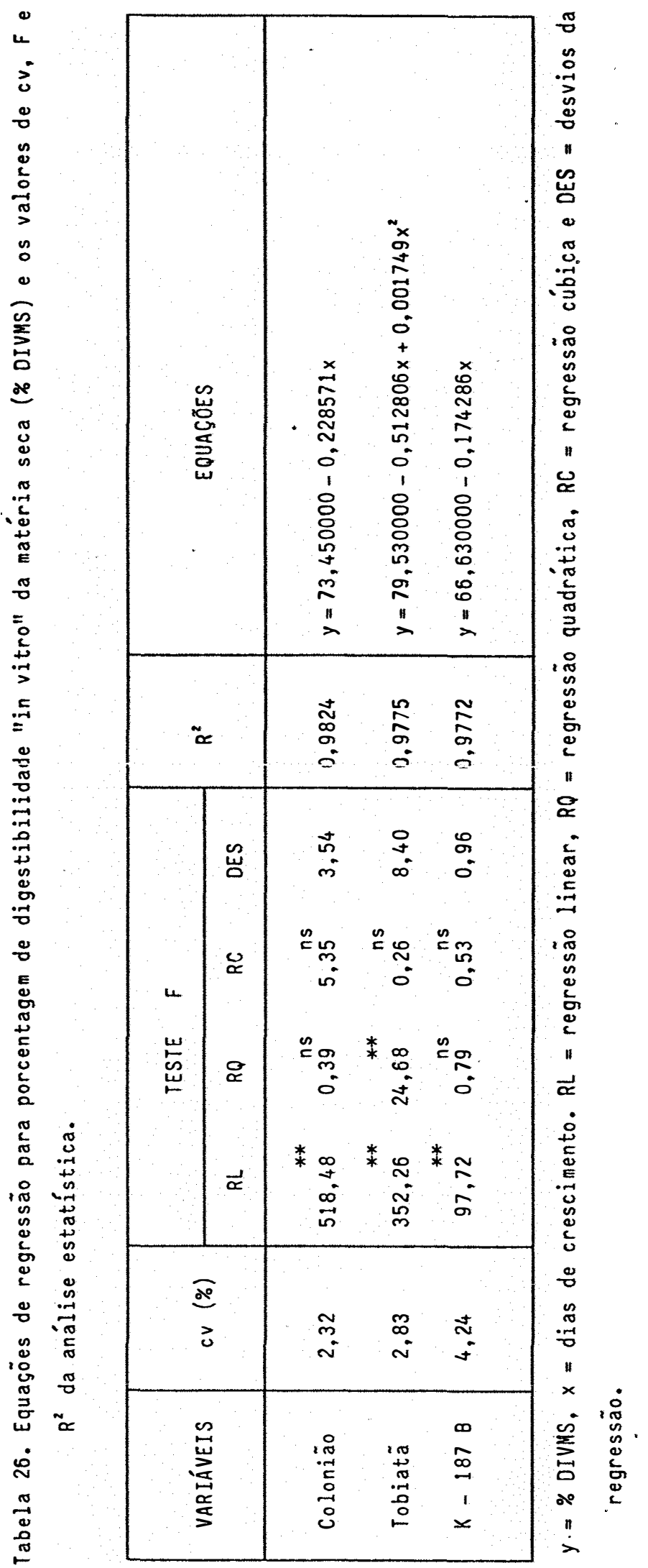




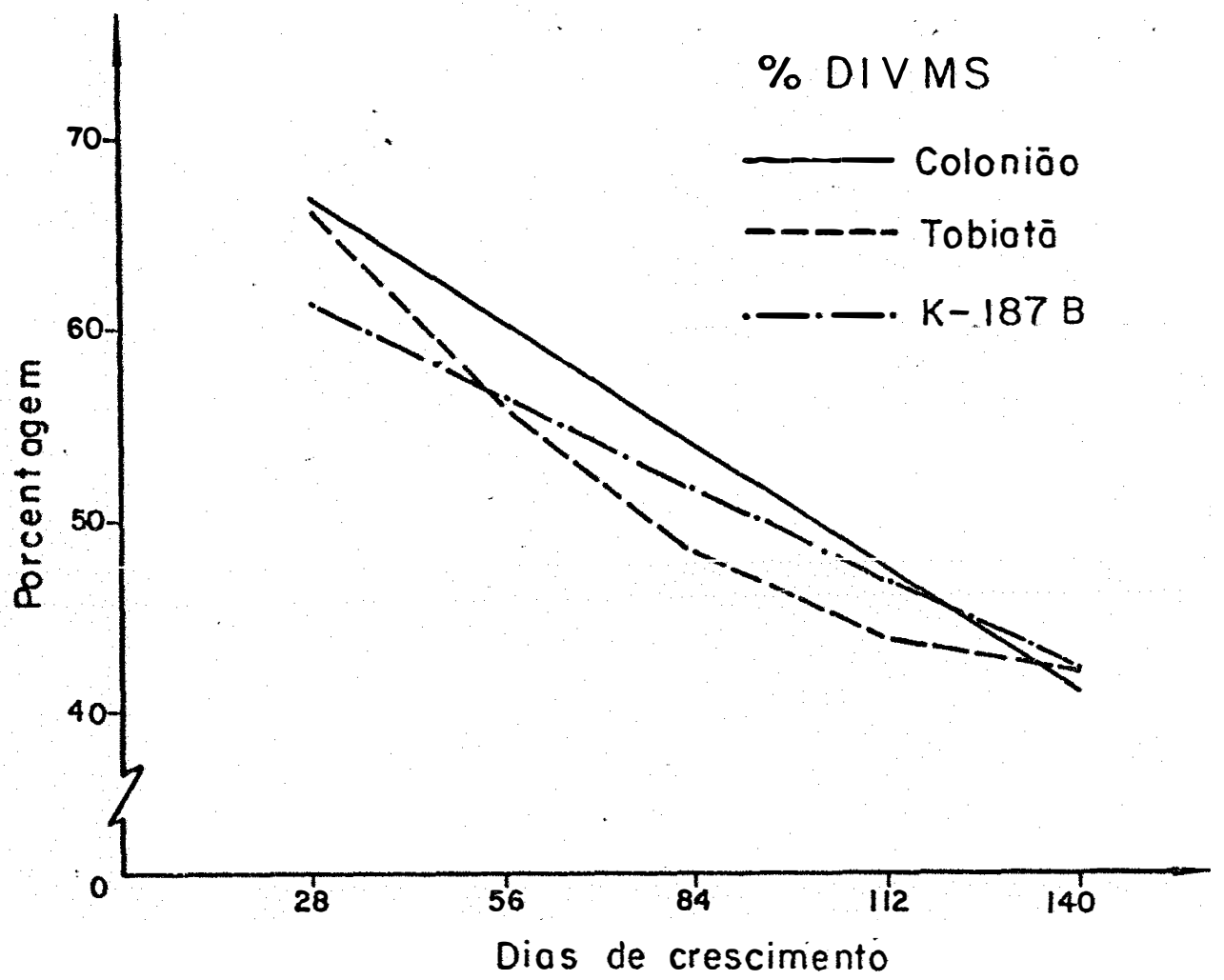

Figura 8 - Curvas que representam os padrōes de variacōo da digestibilidade "in vitro" da materia seca (\% DIVMS). 
K-187 B apresentaram o mesmo padrão de variação dos teores de fósforo da lâmina foliar com as idades de corte. Desta forma, pode-se representar este padrão de variação por uma única equação de regressão.

A Tabela 27 mostra as equações de regressão para os teores de fósforo, potássio e enxofre da lâmina foliar, e - os valores de cv, F e $R^{2}$ da análise estatística.

A Figura 9 mostra as curvas que representam os padrões de variação dos teores de fósforo, potássio e enxofre, da lâmina foliar.

A variação dos teores de fósforo da lâmina foliar com as idades de corte observada neste trabalhoé semelhante à verificaua por PEDREIRA e SILverna (1372), para lâmina fo liar do capim colonião, e GOMIDE et alii (1979 a) para planta inteira de colonião.

A análise de variância mostrou que os teores de potássio da lâmina foliar diferiram nas diversas idades de cor te estudadas $(P<0,01)$. A interação capim $x$ idade de corte não foi significativa. Logo, pode-se concluir que os capins colonião, tobiatã e k-187 B apresentaram o mesmo padrão de variação dos teores de potássio da lâmina foliar com as idades de corte. Desta forma, este padrão de variação pode ser representa do por uma única equação de regressão (Tabela 27).

A variação dos teores de potássio da lâmina foliar observada neste trabalho é semelhante à verificada por GOMIDE et alii (1969 b) para plantas inteiras de outros 6 ca- 


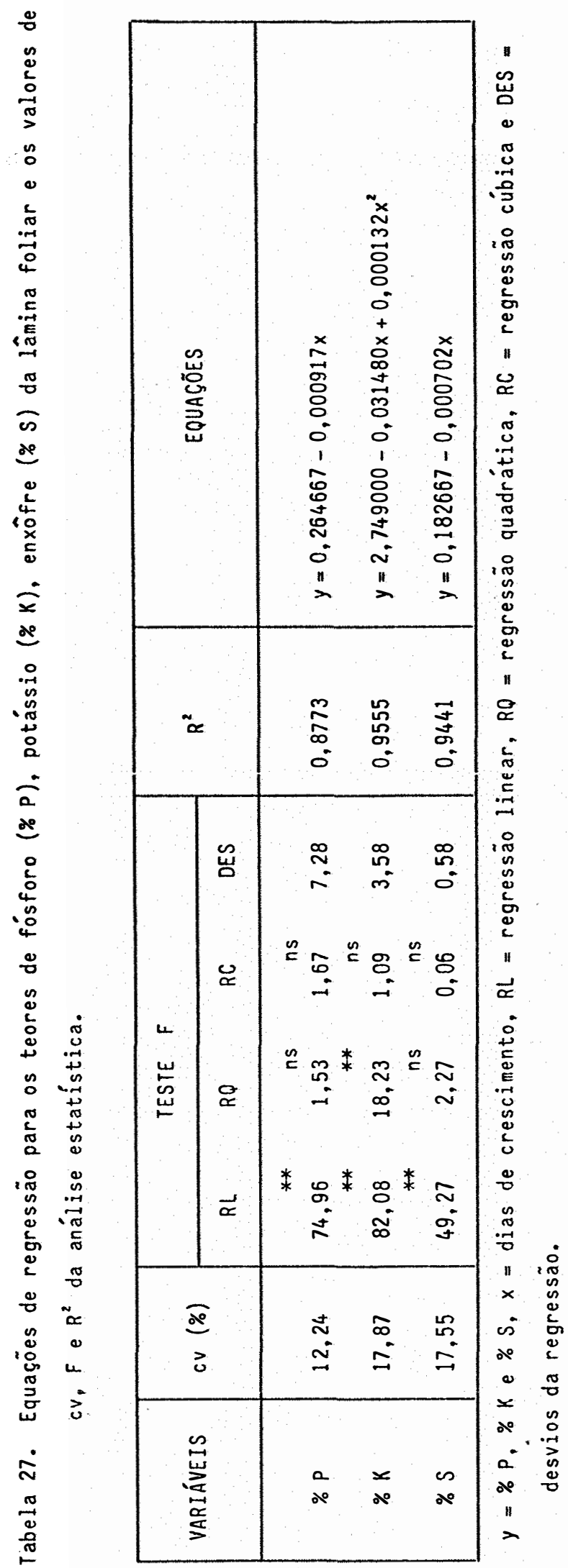




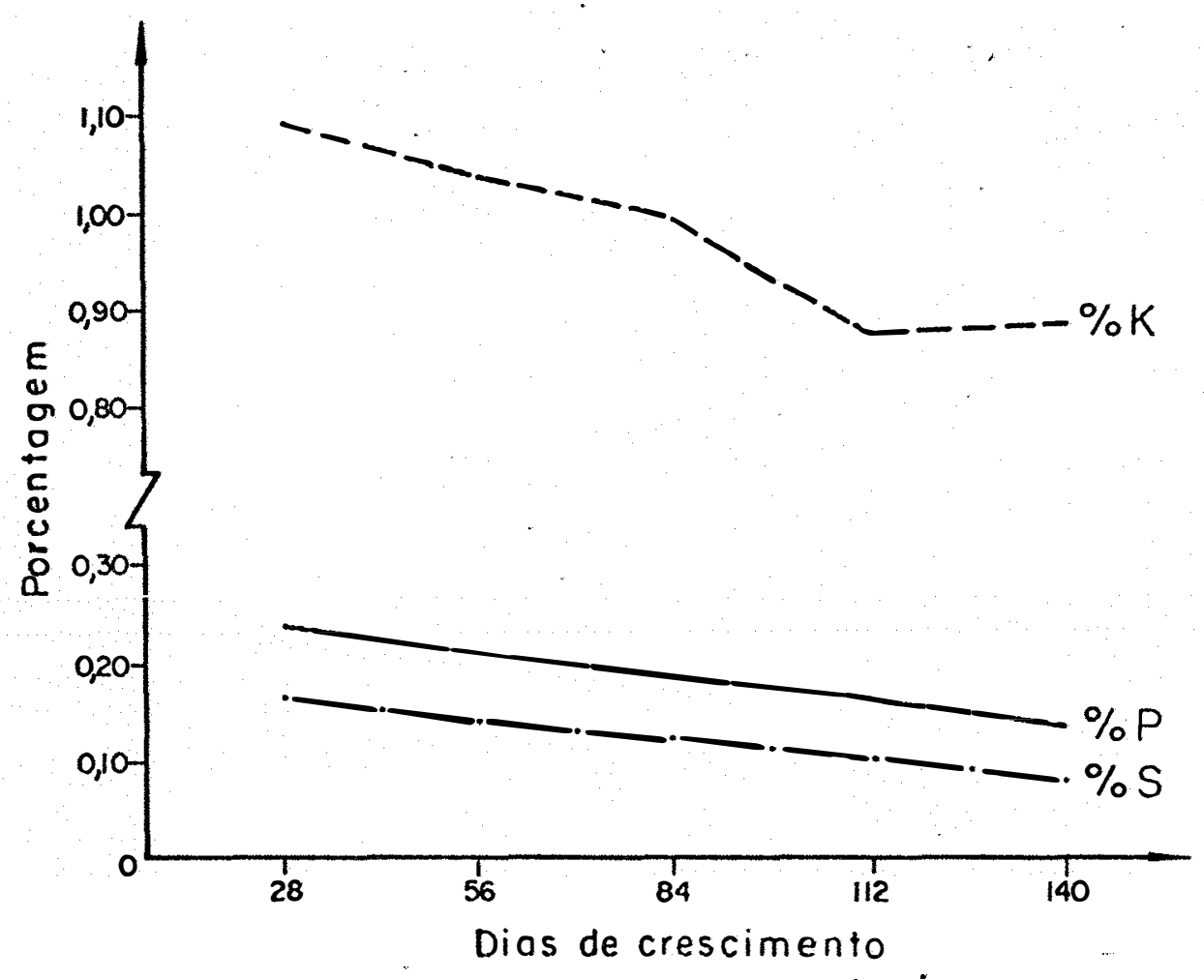

Figura 9-Curvas que representam os padrōes de variação dos teores de fósforo $(\% P)$, potássio $(\% K)$ e enxôfre $(\% S)$. 
pins tropicais.

A análise de variância mostrou que os teores de enxofre da lâmina foliar diferiram nas diversas idades de corte estudadas $(P<0,01)$. A interação capim $x$ idade de corte não foi significativa. Esses resultados sugerem que os capins colonião, tobiatã e K-187 B apresentaram o mesmo padrão de variação dos teores de enxofre da lâmina foliar com as idades de corte, podendo o mesmo ser representado por uma única equação de regressão (Tabela 27 ).

A análise de variância mostrou que os teores de cálcio da lâmina foliar não diferiram nas diversas idades de corte estudadas. Também a interação capim x idades de corte não foi significativa. Esses resultados mostram que os capins colonião, tobiatã e K-187 B apresentaram o mesmo padrão de variação dos teores de cálcio da lâmina foliar com as idades de corte. A análise de variância utilizando-se a regressão para idade de corte, mostrou que não há significância para a variação dos teo res de cálcio, indicando que estes teores não variaram com a ma turação da planta.

A variação dos teores de cálcio na lâmina foliar com as idades de corte observada neste trabalho é semelhante à verificada por PEDREIRA e SILVEIRA (1972) para a lâmina foliar do capim colonião.

A análise de variância mostrou que os teores de magnésio da lâmina foliar não diferiram nas diversas idades de corte estudadas. A interação capim $x$ idades de corte não foi 
significativa. Esses resultados demonstram que os capins colonião, tobiatã e K-187 B apresentaram o mesmo padrão de variação dos teores de magnésio da lâmina foliar com as idades de corte. A análise de variância utilizando-se a regressão para idade de corte, mostrou que não há significância para a variação dos teo res de magnésio, demonstrando que estes teores não variaram com a maturação da planta.

Para a planta inteira, GOMIDE et alii (1969 b) trabalhando com 6 capins tropicais encontraram a mesma variação. Entretanto com planta inteira de colonião, GOMIDE et alii (1979 a) encontraram um decréscimo nos teores de magnésio com a maturação.

A anälise de variância mostrou que as reiações nitrogênio:enxofre da lâmina foliar não diferiram nas diversas idades de corte estudadas. A interação capim $\mathrm{x}$ idade de corte também não foi significativa, mostrando que os capins colonião, tobiatã e K-187 B apresentaram o mesmo padrão de variação das relações nitrogênio:enxofre da lâmina foliar com as idades de corte. A análise de variância utilizando-se a regressão para idade de corte mostrou que não há significância para a variação das relações nitrogênio:enxofre, mostrando que estas não variaram com a maturação da planta.

A análise de variáncia mostrou que os teores de cobre da lâmina foliar diferiram nas diversas idades de corte estudadas $(P<0,01)$. A interação capim $x$ idade de corte não foi significativa. Esses resultados permitem concluir que os 
capins colonião, tobiatã e $\mathrm{K}-187 \mathrm{~B}$ apresentaram o mesmo padrão de variação dos teores de cobre da lâmina foliar com as idades de corte. Desta maneira, este padrão de variação pode ser representado por uma única equação de regressão.

A Tabela 28 mostra as equações de regressão para os teores de cobre, ferro e zinco da lâmina foliar, e os valores de $c v, F$ e $R^{2}$ da análise estatística.

A Figura 10 mostra as curvas que representam os padrões de variação dos teores de cobre, ferro e zinco..

A variação dos teores de cobre da lâmina foliar com as idades de corte observada neste trabalho é semelhante à verificada por GOMIDE et alii (1979 a) para a planta inteira

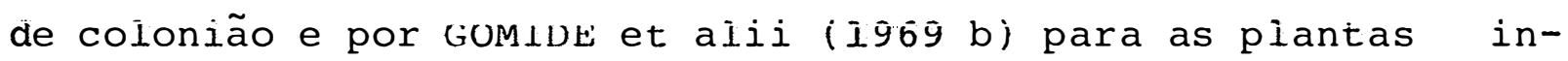
teiras de outros 6 capins tropicais.

A análise de variância mostrou que os teores de ferro da lâmina foliar diferiram nas diversas idades de corte estudadas $(P<0,01)$. A interação capim $x$ idade de corte não foi significativa, sugerindo que os capins colonião, tobiatã e K-187 B apresentaram o mesmo padrão de variação dos teores de ferro da lâmina foliar com as idades de corte. Desta forma, esse padrão de variação pode ser representado por uma única equação de regressão (Tabela 29).

A variação dos teores de ferro das lâminas foliares com as idades de corte observadàs neste trabalho é semelhante à verificada por GOMIDE et alii (1979 a) para a planta inteira de capim colonião e por GOMIDE et alii (1969 b) para 


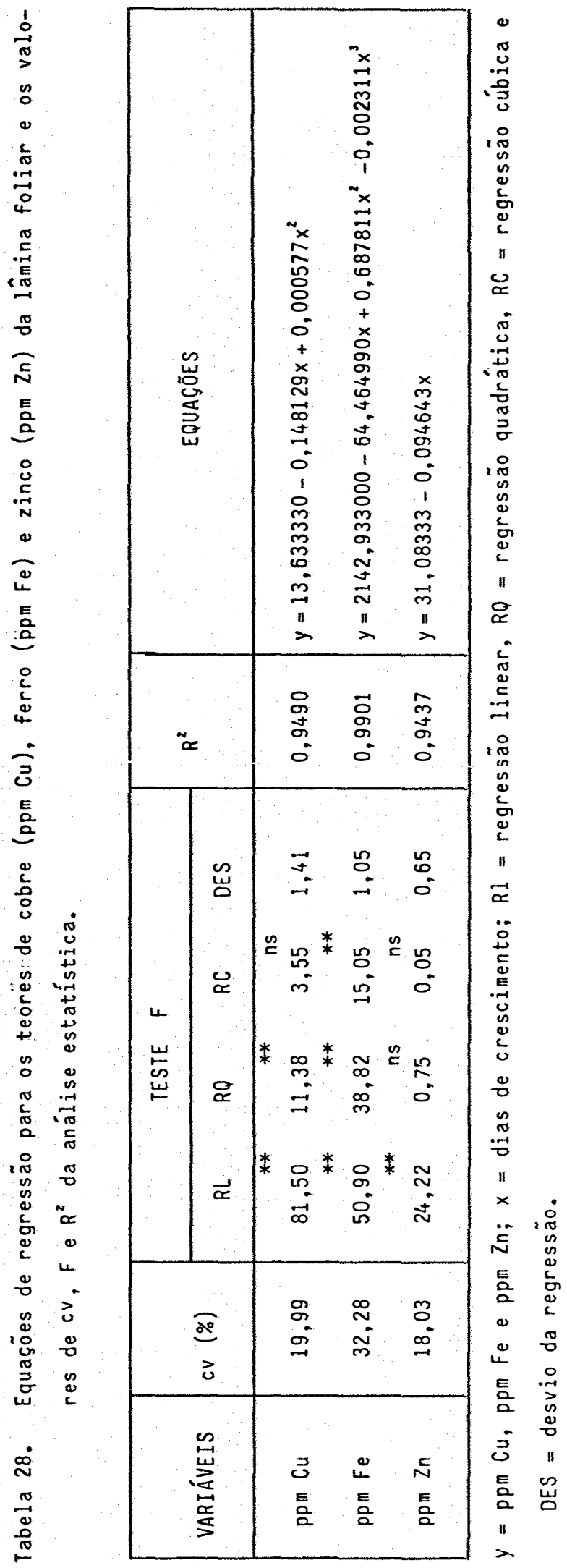




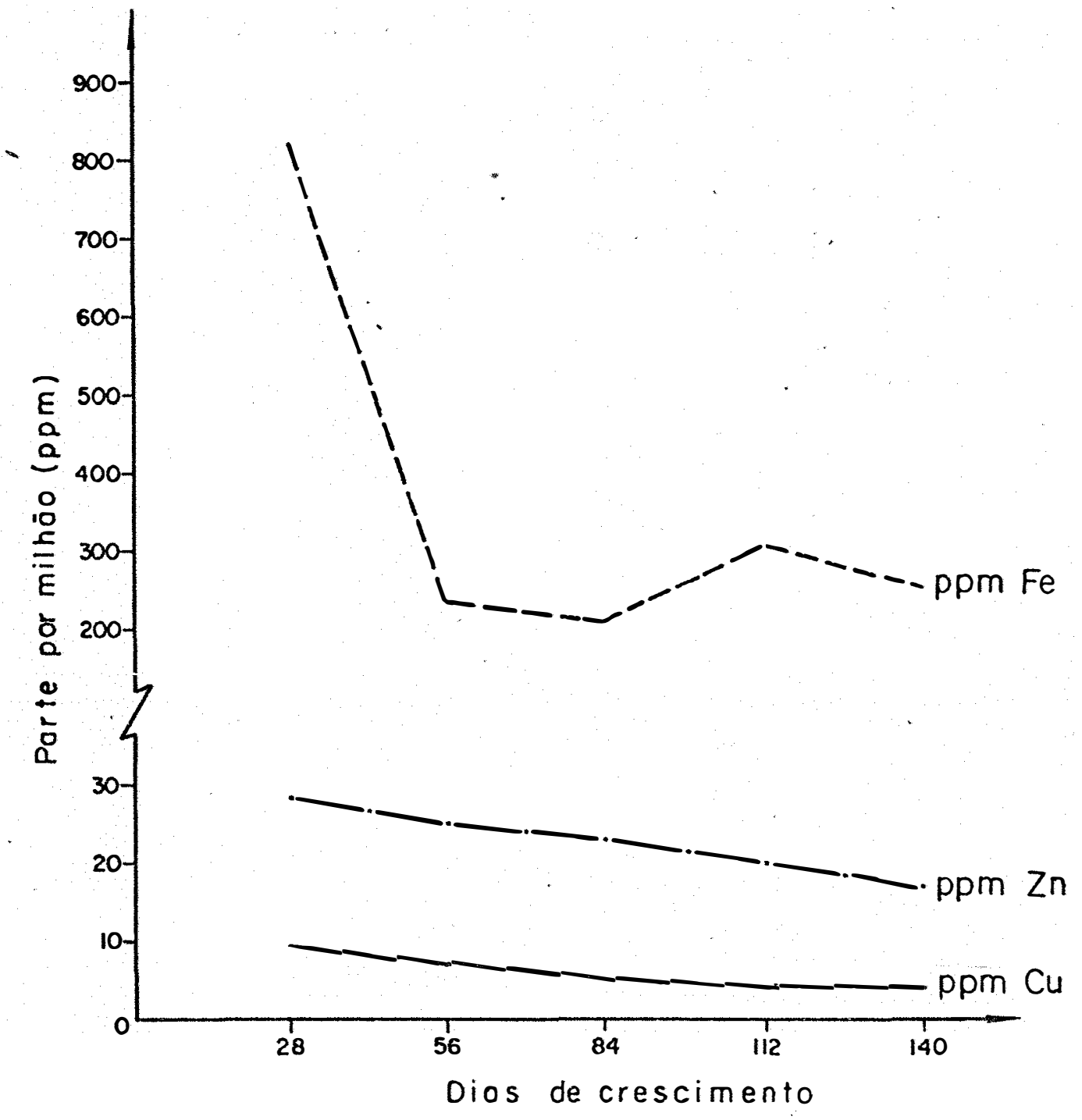

Figura 10 - Curvas que representam os padrōes de variaçāo dos teores de cobre (ppm Cu), ferro (ppm Fe) e zinco $(p p m Z n)$. 
plantas inteiras de outros 6 capins tropicais.

A análise de variância mostrou que os teores de manganês da lâmina foliar não diferiram nas diversas idades estu dadas. A interação capim $x$ idade de corte não foi significativo. Pode-se concluir que os capins colonião, tobiatã e K-187 b apre sentaram o mesmo padrão de variação dos teores de manganês da lâmina foliar com as idades de corte. A análise de variância utilizando-se a regréssão para idade mostrou que não há significância para a variação dos teores de manganês da lâmina foliar, mostrando que estes teores não variaram com a maturação da plan ta.

A variação dos teores de manganès da lâmina foliar com as idades de corte observada neste trabalho difere da encontrada por GOMIDE et alii (1979 a), que registraram uma queda nos teores desse elemento na planta inteira do capim colonião com a maturação da planta. Todavia, GOMIDE et alii (1969 b) encontraram que a variação dos teores de manganês de plantas inteiras de outros 6 capins tropicais não tinham uma tendência definida com a maturação da planta.

A análise de variância mostrou que os teores de zinco da lâmina foliar diferiram nas diversas idades de corte estudadas $(P<0,01)$. A interação capim $x$ idade de corte não foi significativa. Esses resultados mostram que os capins colonião, tobiatã e K-187 B apresentaram o mesmo padrão de variação dos teores de zinco da lâmina foliar com as idades de corte.Des ta forma, este padrão de variação pode ser representado por 
uma única equação de regressão (Tabela 28).

A variação dos teores de zinco da lâmina foliar observada neste trabalho é semelhante a registrada por GOMIDE et alii (1979 a) para planta inteira de capim colonião e por GOMIDE et alii (1969 b) para plantas inteiras de outros 6 capins tropicais. 
5. CONCLUSÕES

Fazendo-se uma análise geral dos resultados obtidos pode-se verificar que ocorreram diferenças significativas entre capins em 18 das 33 variáveis estudadas.

A aplicação do teste Tukey. $(P<0,05)$ mostrou que os capins colonião IZ-1 e tobiatã apresentaram diferenças significativas em 16 das 33 variáveis estudadas: ganho acumula tivo de matéria seca do material verde, número de perfilhos por área, peso médio dos perfilhos, relação lâmina:haste, altura do meristema apical, teores de matéria seca, fibra bruta, participação porcentual de proteína bruta de lâmina em relação à planta inteira, participação porcentual de proteína bruta de haste em relação à planta inteira, fibra insolúvel em detergen te ácido, hemicelulose, celulose, enxofre, zinco, porcentagem 
de digestibilidade "in vitro" da matéria seca e relação nitrogênio:enxofre.

Entre os capins colonião IZ-1 e K-187 B foram verificadas diferenças significativas em 11 das 33 variáveis estudadas: peso médio dos perfilhos, relação lâmina:haste, par ticipação porcentual de proteína bruta de lâmina em relação à planta inteira, participação porcentual de proteína bruta de haste em relação à planta inteira, celulose, lignina, potássio, enxofre, zinco, porcentagem de digestibilidade "in vitro" da matéria seca e relação nitrogènio:enxofre.

Entre os capins tobiatã e K-187 B verificou-se que as diferenças significativas ocorreram em apenas 4 das 33 variáveis estudadas, ou seja, número de perfilihos por área teores de fibra bruta, fibra insolúvel em detergente ácido e celulose.

O efeito significativo de idades de corte ocorreu em 29 das 33 variáveis estudadas. Este efeito somente não foi significativo para as variáveis: teores de cálcio, magnésio, manganês e relação nitrogênio:enxofre. Assim, o fator ida de de corte foi o que mais afetou a produção de matéria seca e a qualidade da forragem em todos os capins estudados.

A interação capim $x$ idade de corte foi significativa para os capins somente para 7 das 33 variáveis estudadas: número de perfilhos por área, teores de fibra bruta, fibra insolúvel em detergente ácido, hemicelulose, celulose, lig nina e porcentagem de digestibilidade "in vitro" da matéria 
seca.

O comportamento dos capins tobiatã e K-187 b foi semelhante para a maioria dessas variáveis, enquanto o capim colonião apresentou um comportamento mais distinto em relação aos outros dois.

Os dados obtidos neste ensaio evidenciaram que - os capins tobiatã e $K_{\imath}-187$ B tiveram comportamento semelhantes como plantas forrageiras, enquanto o capim colonião teve comportamento diferente em relação aos dois primeiros. 
6. LITERATURA CITADA

ANDRADE, I.F. e J.A. GOMIDE, 1971. Curva de crescimento e valor nutritivo do capim elefante (Pennisetum purpureum Schum.) "A-146 Taiwan". Revista da Sociedade Brasileira de Zootecnia, Viçosa, 18(100):421-447.

ANDRADE, P. 1973. Variações nos componentes da parede celular e digestibilidade "in vitro" da fibra das forrageiras, capim gordura (Melinis minutiflora Paul de Beauv.) e capim colonião (Panicum maximum Jacq.) Jaboticabal, FMVAJ, 98 p. (Tese de Doutoramento).

ASSOCIATION OF OFFICIAL AGRICULTURAL CHEMISTS - 1969. Official. methods of analysis. 9 th ed. Washington D.C., AOAC, 832 p. 
BARNES, D.L. 1960. Growth and management studies on Sabi panicum and Star grass. part I. Rhodesia Agricultural. Journal, Salisbure, 57:395-411.

BOOYSEN, P., M.N. TAITON E J.D. SCOTT., 1963. Shoot apex development in grasses and its importance in grassland mangement. Herbage Abstracts, Hurley, Berks, 33 (4):209-213.

BOTREL, M.A. E J.A. GOMIDE. 1981. Importância do teor dos carboidratos de reserva e da sobrevivência dos meristemas apicais para a rebrota do capim jaraguá (Hyparrhenia rufa (Ness.) Stapf.) . Revista da Sociedade Brasileira de Zootecnia, Viçosa, $10(3): 411-426$.

BOYER, J. 1977. Etude éco-physiologique dé la productivite de quelques graminés fourragéres cultivées au senegal . II. Consommation d'eau et production de matiére séche das parties aeriennes. Cah.O.R.S.T.O.M. ser. Biol., Pa-

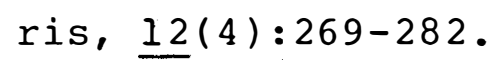

BROUGHAM, R.W. 1955. A study in rate of pasture growth. Australian Journal of Agricultural Research, Melbourne, $\underline{6}(6): 804-812$

CAPIM COLONIÃo "TOBIATÃ". 1982. O Agronōmico, Campinas, sP, 34(Único):7. Edição especial.

CAPIM COLONIÃO IZ-1. 1983/84. In: Coordenadoria de Assistência Técnica Integral, CATI - Descrição de cultivares em multipli 
cação pelo Departamento de Sementes, Mudas e Matrizes, Campinas, SP.

CORSI, M. 1972. Estudo da produtividade e do valor nutritivo do capim elefante (Pennisetum purpureum Schum.). var. napier submetido a diferentes freqüèncias e alturas de corte. Piraciba, ESALQ, 139 p. (Tese de Doutoramento).

costa, N.A. 1982. Efeito do corte em diferentes períodos e idades de crescimento sobre a produção de matéria seca, eliminação de meristemas apicais, desenvolvimento do sistema ra dicular e vigor de rebrota do capim andropogon (Andropogon gayanus Kunth.) var. Bisquamulatus. Piracicaba, ESALQ, 64 p. (Tese de Mestrado).

FERRARIS, R. A D.F. SINCLAIR. 1980 a. Factores affecting the growth of Pennisetum purpureum in the wet tropics. I. Short term growth and regrowth. Australian Journal of Agricultural Research, Melbourne, 31(5):889-913.

FERRARIS, R. e D.F. SINCLAIR. 1980 b. Factores affecting the growth of Pennisetum purpureum in the wet tropics. II . Uninterrupted growth. Australian Journal of Agricultural Research, Melbourne, 31(5):915-925.

FLORIO, A. 1976. Componentes da parede celular de gramíneas forrageiras em estudo de adaptação no Vale do Ribeira. Jaboticabal, FMVAJ, 46 p. (Trabalho de graduação em Zootecnia). 
GALLO, J.R.; R. HIROCE; O.C. BATAGLIA; P.R. FURLANI; A.M.C. FURLANI, H.C. SARTINI E M.P. FONSECA. 1974 . Composição química inorgánica de forrageiras do Estado de são Paulo. Boletim de Indústria Animal, São Paulo, 31(3):115-137.

GOERING, H.K. e P.J; VAN SOEST. 1970. Forage Fiber Analyses. (Apparatus, reagentes, procedures, and some applications) Washington, USDA, Agricultural Research Service. 20 p. (Agriculte Handbook, 379).

GOMIDE, J.A.; C.H. NOLLER; G.O. MOTT; J.H. CONRAD e D.L; HILL . 1969 a. Effect of plant age and nitrogen fertilization on the chemical composition and "in vitro" cellulose digestibility of tropical grasses. Agronomy Journal, Madison, 6l(1): $116-120$.

GOMIDE, J.A.; C.H. NOLLER, G.O. MOTT, J.H. CONRAD E D.L. HILL. $1 y 69$ b. Mineral composition of six tropical grasses as influenced by plant age and nitrogen fertilization. Agronomy Journal, Madison, 61(1):120-123.

GOMIDE, J.A. 1973. Fisiologia do crescimento livre de plantas forrageiras. In: Simpósio sobre manejo das pastagens. ESALQUSP, p. 83-93.

GOMIDE, J.A.; J.A. OBEID e J.F.T. NETO. 1979 a. Produtividade e valor nutritivo do capim colonião (Panicum maximum). Revista da Sociedade Brasileira de Zootecnia, Viçosa, 8(2):198-2.25. 
GOMIDE, J.A.; J.A. OBEID e L.R.A. RODRIGUES, 1979 b. Fatores morfofisiológicos de rebrota do capim colonião (Panicum maximum). Revista da Sociedade Brasileira de Zootecnia, Viçosa, $8(4): 532-562$.

GOMIDE, J.A. e C.P. ZAGO. 1980. Crescimento e recuperação do capim colonião após corte - Revista da Sociedade Brasileira de Zootecnia, Viçosa, 9 (2):239-305.

HACKER, J.B. E D.J. MINSON. 1981. The digestibility of plant parts. Herbage Abstracts, Hurley, Berks, 51(9):459-482.

JEWISS, O.R. 1966. Morphological and physiological aspects of grasses during the vegetative phase. In: MILTHORPE, F.L. e J.D. IVINS. The growth of cereals and grasses. Butterworths, London, p. 39-56.

JEWISS, O.R. 1972. Tillering in grasses: its significance and control. Journal of the British Grassland Society, Hurley, Berks, 27:52-82.

KENNEDY, P.M. e B.D. SIEBERT. 1972. The utilization of spear grass(Heteropogon contortus). Australian Journal of Agricultural Research, Melbourne, 24 (1):143-152.

LANGER, H.M. 1958. A study of growth in sward of timothy and meadow fescue. I. Uninterrupted growth. Journal Agriculture Science, Cambridge, 51(3):347-352. 
LANGER, H.M. 1963. Tillering in herbage grasse. Herbage Abstracts, Hurley, Berks, 33(1):141-148.

LEOPOLD, A.C. The control of tillerinf in grasse by auxin. American Journal of Botany, Lancaster, 36:141-148.

LOTT, W.L.; J.P. NERY, J.R. GALLO e J.C. MEDCALF. 1956. A técnica da análise foliar aplicada ao cafeéiro. Bull. IBEC. Res. Inst., New York, no 9, 40 p.

MECELIS, N.R. 1979. Estudo da rebrota do capim colonião (Panicum maximum Jacq.) submetido a diferentes tipos de manejo. Jaboticabal, UNESP, 57 p. (Tese de Mestrado).

MINSON, D.J. 1971. The digestibility and voluntary intake of six varieties of Panicum. Australian Journal of Experimental Agriculture and Animal Husbandry, Melbourne, $11(48): 18-25$.

MINSON, D.J. 1980. Effects of chemical and physical composition of herbage eaten upon intake. In: WHEELER, J.L. e R. D. MIOCHRIE, Forage evaluation: Concepts and technique. American Forage and Grassland Concil (CSIRO), 167-181;

NASCIMENTO, Jr., D. e J.S. PINHEIRO. 1975. Desenvolvimento vegetativo do capim jaraguá. Revista da Sociedade Brasileira de Zootecnia; Viçosa, $\underline{4}(2): 147-157$.

NASCIMENTO, M.P.S.C.B.; T.S. NASCIMENTÓ E J.A. GOMIDE. 1980. Alguns aspectos morfofisiológicos de très gramineas de clima 
tropical. Revista da Sociedade Brasileira de Zootecnia , Viçosa, $\underline{9}(1): 142-158$.

NATIONAL RESEARCH COUNCIL (1984). Subcommittee on Beef Cattle Nutrition. Nutrient requeriments of beef cattle. 6. rev. ed. Washington, DC, National Academy Press.

PEDREIRA, J.V.S. 1965. Desenvolvimento de plantas forrageiras e sua importáncia no manejo de pastagens. Zootecnia, são Paulo, $3(3): 31-40$

PEDREIRA, J.V.S. 1965/66. Estudo de crescimento do capim colơnião (Panicum maximum Jacq.). Boletim de Indústria Animal: São Paulo. $23($ n.u. ) :139-145.

PEDREIRA, J.V.S. e C. BOIN. 1969. Estudo de crescimento do capim elefante var. napier. (Pennisetum purpureum Schum.) . Boletim de Indústria Animal, são Paulo, (n.u.):263-273.

PEDREIRA, J.V.S. e J.J.N. SILVEIRA. 1972. Variação da composi ção bromatológica do capim colonião (Panicum maximum Jacq.) Boletim de Indústria Animal, são Paulo, n.u. 29(1):185-190.

PEDREIRA, J.V.S. 1973. Crescimento estacional dos capins colonião (Panicum maximum Jacq.), gordura (Melinis minutiflora Paul de Beauv), jaraguá (Hyparrhenia rufa (Ness.) Stapf. ) e pangola de Taiwan. A-24 (Digitaria pentzii Stent). Boletim de Indústria Animal, São Paulo, 30(1):59-145. 
PEDREIRA, J.V.S. 1975. Hábitos de perfilhamento do capim colonião (Panicum maximum Jacq.). Boletim de Indústria Animal, São Paulo, $32(1): 111-114$.

PERKIN - ELMER CORPORATION. 1976. Analytical methods for atomic absoration spectrophotometry. Harford, perkin-Elmer, $45 \mathrm{p}$.

PERNES, J.; J. RENE, R. RENE-CHAUME, L. LÉTENNEUR, G. ROBERGE e J.L. MESSAGER. '1975. Panicum maximum Jacq. et l'intensification fourragère en Côte d'Ivoire. Revue D'élevage et de Médicine Vétérinaire des Pays Tropicaux. Paris, n.s. 28(2): 293-294 .

PLAYNE, m.j. 1969. Effects of sodium sulphate and gluten supplements on the intake and digestibility of a misture of spear grass Townsville lucerne hay by sheep. Australian. Journal of Experimental Agriculture and Animal Husbandry, Melbourne, $\underline{9}(39): 393-399$.

PRINE, M.G. e G.M. BURTON. 1956. The effect of nitrogen rate and clipping frequency upon the yield, protein content and certain morphological characteristics of Costal Bermudagrass (Cynodon dactylon (L.) Pers.). Agronomy Journal , Madison, $\underline{43}(6): 296-301$.

REES, M.C., D.J. MINSON e F.W. SMITH. 1974. The effect of suplementary and fertilizer sulphur on voluntary intake , digestibility, retention time in the rumen, and site of 
digestion of pangola grass (Digitaria decumbens) by sheep. The Journal of Agricultural Science, London, 82(3):419-422. REES, M.C. A D.J. MINSON. 1976. Fertilizer sulphur factor affecting voluntary intake, digestibility and retention time of pangola grass (Digitaria decumbens by sheep. The British Journal of Nutrition, London, 39(1):5-11.

SARRUGE, J.R. e H.P. HAAG. 1974. Análises químicas em plantas. Piracicaba, ESALQ/USP, $56 \mathrm{p}$.

SINGH, R.D. e B.N. CHARTERJEE. 1966. Tillering of perenial grasses in the tropics in India. In: Congresso Internacional de Pastagens, São Paulo, Brasil, 1965. Anais... São Paulo, Departamento da Produção Animal, 1966, 2 v., v 2 , p. $1075-1079$.

TARDIN, A.C., G.H. CALLES e J.A. GOMIDE. 1971. Desencolvimento vegetativo do capim guatemala. Experientiae, Viçosa, 12(1): $1-31$.

TILLEY, J.M.A e TERRY, R.A. 1963. A two-stage technique for the in citro digestion of forage crops. Journal of the British Grassland Society, Hurley, Berks, 18:83-85.

THOMAS, C. 1982. Apostila do Curso Internacional sobre Avalia ção de Forragens para Ruminantes, ESALQ- FEALQ, EMBRAPA Michigan State University, Piracicaba, 30 de agosto a 10 de setembro. Mimeo. 
TROUGHTON, A. 1955. Cessation of tillering in young grass. Nature, London, 176 $(4480): 514$.

USBERTI FILHO, J.A. 1982. Tobiatã - Nova cultivar de capim colonião. Casa da Agricultura. Campinas, $\underline{4}(1): 10-11$.

VAN SOEST, P.J. 1965. Use of detergent in analysis of fibrous feeds. II - Study of effects of heating and drying on yield of fiber and lignin in forage. Journal Association. Official Agricultural Chemists, Washington, 48:785-790.

VAN SOEST, P.J. 1967. Development of a comprehensive system of feed analysis and its application to forages. Journal of Animal Science, Albany, 26:119-128.

WHITEMAN, P.C. Coord. 1980. Tropical Pasture Science. Oxford University Press, 392 p. 
116

7. APÊNDICE 


\section{APÊNDICE}

Tabela 29 - Análise de variância do fatorial, para as produçōes de MST, MSV e MSS, bem como os valores da média geral (MG), devio padrão (s) e coeficiente de variação (cv). Análise variância para MST

\begin{tabular}{|c|c|c|c|c|}
\hline C.V. & G.L. & S.Q. & O.M. & $F$ \\
\hline Capim (C) & 2 & $4606 \$ 56,3511$ & 2303478,1756 & $0,82_{* *}^{n s}$ \\
\hline Idade (I) & 8 & $-\cdots-\cdots$ & 217439814,0666 & $77,02^{* *}$ \\
\hline$C \times I$ & 16 & 16589794,0936 & 2036862,1308 & $0,37^{n s}$ \\
\hline (Tratam.) & 26 & - & 67719817,8068 & \\
\hline Blocos & 1 & 9952118,4600 & 9952118,4600 & $3,52^{n s}$ \\
\hline Resíduo & 26 & 73405771,7189 & 2823298,9127 & \\
\hline
\end{tabular}

$M G=11118,9056$

$S=1680,2675 \quad c v=15,11$

Análise de variância para MSV

C.V.

G.L.

S.Q.

Q.M.

Capim (C)

Idade (I)

2

787257861,5073

$C \times I$

16

22133292,6978

6989700,5642

98407245,1884

1383330,7937

$F$

(Tratam.)

26

Blocos

26

1

823370655,3334

7520487,5616

26

47743929,3442

31668102,1282

7520487,5616

1836304,9748

$3,81^{*}$

$53,59^{\circ}$

$0,75^{\text {ns }}$

$M G=8787,6074$

$s=1355,1033$

$c v=15,42$

Análice de variância MSS

C.V.

Capim (C)

Idade (I)

$c \times I$

(Tratam.)

Blocos

Resíduo

$M G=5245,2200$
G.L.

2

3

6

11

1

11 . 5734581,6221
32019361,8573
247713,6671 5734581,6221
32019361,8573
247713,6671

S.Q.

38001657,1465

382547,6001

9611329,8468

$s=934,7498$
Q.M.

2867290,8110

10673120,6191

41285,6112

3454696,1042

382547,6001

873757,2588

$c v=17,82$
$F$

$3,28_{* *}^{\text {ns }}$

$12,22^{* *}$

$0,05^{\text {ns }}$

$0,44^{\text {ns }}$ 
Tabela 30 - Análise de variância do fatorial e os respectivos desdobramentos, para o número de perfilhos por área, bem como os valores da média geral (MG), desvio padrão (s) e coeficiente de variação. (cv)

Análise de variância para número de perfilhos

\begin{tabular}{lrrrr} 
C.V. & G.L. & S.Q. & Q.M. & F \\
Capim (C) & 2 & 9268,0370 & 4634,0185 & $47,40^{* *}$ \\
Idade (I) & 8 & 463387,2593 & 57923,4074 & $146,36^{* *}$ \\
C.I & 16 & 38277,6296 & 2392,3519 & $6,04^{*}$ \\
\hline (Tratam.) & 26 & 510932,9259 & 19651,2664 & \\
Blocos & 1 & 106,9630 & 106,9630 & $0,27^{\text {ns }}$ \\
Resíduo & 26 & 10290,0370 & 395,7707 & \\
\hline MG $=153,9630$ & & $S=19,8940$ & CV $=12,9213$ &
\end{tabular}

Desdobramento de Idade dentro de Capim

\begin{tabular}{|c|c|c|c|c|}
\hline C.V. & G.L. & S.0. & Q.M. & $F$ \\
\hline I. d C. 1 & 8 & 150089,7778 & 18761,2222 & $47,40_{* *}^{* *}$ \\
\hline I. dC. 2 & 8 & 214702,0000 & 26037,7500 & $07,81_{* *}^{* *}$ \\
\hline I. $d c .3$ & 8 & 136873,1111 & 17109,1389 & $43,23^{\pi}$ \\
\hline
\end{tabular}

(I. d C. $\quad(24) \quad(501664,8889)$

Desdobramento de Capim dentro de Idade

\begin{tabular}{|c|c|c|c|c|}
\hline C.V. & G.L. & S.0. & Q.M. & $F$ \\
\hline c. d I. 1 & 2 & 19003,0000 & 9501,5000 & $24,01_{* *}^{* *}$ \\
\hline C. d I. 2 & 2 & 7464,3333 & 3732,1667 & $9,43^{* *}$ \\
\hline c. d I. 3 & 2 & 417,3333 & 208,6667 & $0,53_{* *}^{\text {ns }}$ \\
\hline c. d I. 4 & 2 & 16156,0000 & 8078,0000 & $20,41_{n s}^{*}$ \\
\hline c. d I. 5 & 2 & 2076,3333 & 1038,1667 & $2,62^{\text {ns }}$ \\
\hline c. d I. 6 & 2 & 1153,0000 & 576,5000 & $1,46^{\mathrm{ns}}$ \\
\hline c. d I. 7 & 2 & 460,3333 & 230,1667 & $0,58^{\mathrm{ns}}$ \\
\hline c.d I. 8 & 2 & 463,0000 & 231,5000 & $0,58_{n s}^{n s}$ \\
\hline C. d I. 9 & 2 & 352,3333 & 176,1667 & 0,45 \\
\hline
\end{tabular}

(c. d I.) (18) $\quad(47545,6667)$


Tabela 31 - Análise de variância do fatorial, para peso médio de perfilho, relação lâmina : haste e altura da cultura, bem como os valores da média geral (MG), desvio padrão (s) e coeficiente de variação (cv)

Análise de variância para peso médio de perfilho.

\begin{tabular}{lrrrr} 
C.V. & G.L. & S.Q. & Q.M. & F \\
Capim (C) & 2 & 42,4878 & 21,2439 & $8,44^{* *}$ \\
Idade (I) & 8 & 944,5433 & 118,0679 & $46,93^{\text {** }}$ \\
CXI & 16 & 34,5789 & 2,1612 & $0,86^{\text {ns }}$ \\
\hline (Tratam.) & 26 & 1021,6100 & 39,2927 & $7,39^{*}$ \\
Blocos & 1 & 18,6091 & 18,6091 & \\
Resíduos & 26 & 65,4159 & 2,5160 & \\
\hline
\end{tabular}

$M G=6,3500$

$s=1,5862$

$c v=24,98$

Análise de variância para relação lâmina:haste

\begin{tabular}{lrrrr} 
C.V. & G.L. & S.Q. & $0 . M$. & F \\
Capim (C) & 2 & 0,4826 & 0,2413 & $26,22^{* *}$ \\
Idade (I) & 8 & 8,8204 & 1,1025 & $119,81^{\text {ns }}$ \\
C*I & 16 & 0,2207 & 0,0138 & $1,50^{\text {s }}$ \\
\hline (Tratam.) & 26 & 9,5237 & 0,3663 & \\
Blocos & 1 & 0,0007 & 0,0007 & $0,08^{\text {ns }}$ \\
Resíduo & 26 & 0,2393 & 0,0092 & \\
\hline
\end{tabular}

NG $=0,9259$

$s=0,0959$

$c V=10,36$

Análise de variancia para altura da cultura

\begin{tabular}{lrrrr} 
C.V. & G.L. & S.Q. & Q.M. & F \\
Capim (C) & 2 & 372,9462 & 186,4731 & $1,42^{\text {ns }}$ \\
Idade (I) & 6 & 114581,8514 & 19096,9752 & $145,25^{\text {ns }}$ \\
C XI & 12 & 2677,5771 & 223,1314 & $1,70^{\text {ns }}$ \\
\hline (Tratam.) & 20 & 117632,3748 & 5881,6187 & \\
Blocos & 1 & 630,2688 & 630,2688 & $4,79^{*}$ \\
Resíduo & 20 & 2629,5262 & 131,4763 & \\
\hline MG $=142,7310$ & & $S=11,4663$ & $c V=8,03$ &
\end{tabular}


Tabela 32 - Análise de variância do fatorial, para altura do meristema apical, vigor de rebrota e teor de matéria seca, bem como os valores da média geral (MG), desvio padrão (s) e coeficiente de variação (cv)

Análise de variância para altura do meristema apical

\begin{tabular}{lrrrr} 
C.V. & G.L. & S.Q. & Q.M. & \multicolumn{1}{c}{ F } \\
Capim (C) & 2 & 763,2648 & 384,1324 & $5,94^{* *}$ \\
Idade (I) & 6 & 46313,8881 & 7718,9813 & $119,27^{* *}$ \\
C & 12 & 881,2519 & 73,4377 & $1,13^{\text {ns }}$ \\
\hline (Tratam.) & 20 & 47963,4048 & 2398,1702 & $5,29^{*}$ \\
Blocos & 1 & 342,2860 & 342,2860 & \\
Resíduo & 20 & 1294,3390 & 64,7170 &
\end{tabular}

$M G=42,5024$

$s=8,0447$

$c v=18,93$

Análise de variância para vigor de rebrota

C.V.

G.L.

S.Q.

Q.M.

F

Capim (C)

2

427577,1689

1079651,8488

Idade (I)

788746,4927

213788,5845

359883,9496

$3,43^{\text {ns }}$

C XI

6

$13145 \%, 1488$

5,77

$0 \times 1 \ldots \ldots$

(Iratam.)

11

2295975,5104

Blocos

11

2962,1482

686431,9394
208725,0464
2962,1482
62402,9036

$2,11^{n s}$

Resíduo

11

$s=249,8057$

$c V=26,59$

Análise de variância para teor de matéria seca

\begin{tabular}{lrrrr} 
C.V. & G.L. & S.Q. & Q.M. & \multicolumn{1}{c}{$F$} \\
Capim (C) & 2 & 48,2781 & 24,1391 & $4,96^{*}$ \\
Idade (I) & 8 & 2892,6104 & 361,5763 & $74,25^{\text {ns }}$ \\
$C \times I$ & 16 & 82,7352 & 5,1709 & $1,06^{n}$ \\
\hline (Tratam.) & 26 & 3023,6237 & 116,2932 & \\
Blocos & 1 & 0,0600 & 0,0600 & $0,01^{\mathrm{ns}}$ \\
Resíduo & 26 & 126,6200 & 4,8700 &
\end{tabular}

$M G=30,6259$

$s=2,2068$

$c v=7,21$ 
Tabela 33 - Análise de variância do fatorial e os respectivos desdobramentos,para o teor de fibra bruta, bem como os valores da média geral (MG), desvio padrão (s) e coefi ciente de variạção (cv).

Análise de variância para teor de fibra bruta

\begin{tabular}{lrrrr} 
C.V. & G.L. & S.Q. & Q.M. & $F$ \\
Capim (C) & 2 & 34,1526 & 17,0763 & $6,96^{* *}$ \\
Idade (I) & 8 & 1474,5504 & 184,3188 & $75,14^{* *}$ \\
C xI & 16 & 127,6574 & 7,9786 & $3,25^{* *}$ \\
\hline (Tratam.) & 26 & 1636,3604 & 62,9369 & \\
Blocos & 1 & 4,5646 & 4,5646 & $1,86^{\text {ns }}$ \\
Resíduo & 26 & 63,7804 & 2,4531 & \\
\hline$M G=43,6093$ & & $S=1,5662$ & cV $=3,59$
\end{tabular}

Desdobramento de Idade dentro de Capim

C.V. G.L. S.Q. Q.M. F

$\begin{array}{lllll}\text { I. d C. } 1 & 8 & 75 \hat{y}, 757 \overline{8} & \bar{y} \dot{4}, \bar{y} \hat{y} \bar{j} & 3 \hat{8}, 71^{* *} \\ \text { I. d C. } 2 & 8 & 430,7200 & 53,8400 & 21,95^{* *} \\ \text { I. d C. } 3 & 8 & 411,7300 & 51,4663 & 20,98\end{array}$

(I. dC. $\quad(24) \quad(1602,2078)$

Desdobramento de Capim dentro de Idade

\begin{tabular}{|c|c|c|c|c|}
\hline C.V. & G.L. & $S . Q$. & Q.M. & $F$ \\
\hline c. d 1. 1 & 2 & 41,6100 & 20,8050 & $8,48^{* *}$ \\
\hline c. d I. 2 & 2 & 3,3700 & 1,6850 & $0,69_{* *}^{\text {ns }}$ \\
\hline c. d I. 3 & 2 & 54,4933 & 27,2467 & $11,11_{n c}^{n}$ \\
\hline c. d I. 4 & 2 & 4,5700 & 2,2850 & $0,93_{*}^{n s}$ \\
\hline c. d I. 5 & 2 & 26,8633 & 13,4317 & $5,48_{*}$ \\
\hline c. d I. 6 & 2 & 21,4933 & 10,7467 & $4,38_{n s}^{n}$ \\
\hline c. d I. 7 & 2 & 5,3033 & 2,6517 & $1,08^{\text {ns }}$ \\
\hline c. d I. 8 & 2 & 0,6633 & 0,3317 & $0,14^{\mathrm{ns}}$ \\
\hline c.d I. 9 & 2 & 3,4433 & 1,7217 & $0,70^{110}$ \\
\hline
\end{tabular}

(c.dI.) (18) $\quad(161,8100)$


Tabela 34 - Análise de variância do fatorial, para os teores de proteína bruta da planta in teira, da lâmina e da haste, bem como os valores da média geral (MG), desvio padrão (s) e coeficiente de variação (cv).

Análise de variância para teor de proteína bruta da planta inteira

\begin{tabular}{lrrrr} 
C.V. & G.L. & \multicolumn{1}{c}{ S.Q. } & $0 . M$. & \multicolumn{1}{c}{$F^{*}$} \\
Capim (C) & 2 & 10,9404 & 5,4702 & $2,64^{\text {ns }}$ \\
Idade (I) & 8 & 992,4237 & 124,0530 & $59,91^{\text {ns }}$ \\
C XI & 16 & 62,7763 & 3,9235 & $1,89^{\text {ns }}$ \\
\hline (Tratam.) & 26 & 1066,1404 & 41,0054 & $10,71^{* *}$ \\
Blocos & 1 & 22,1696 & 22,1696 & \\
Resíduo & 26 & 53,8404 & 2,0708 & \\
\hline
\end{tabular}

Análise de variância para teor de proteína bruta de lâmina

\begin{tabular}{lrrrr} 
C.V. & G.L. & S.Q. & Q.M. & \multicolumn{1}{c}{ F } \\
Capim (C) & 2 & 3,4133 & 1,7067 & $0,92^{\text {ns }}$ \\
Idade (I) & 8 & 727,9333 & 90,9917 & $49,13^{\text {ns }}$ \\
CXI & 16 & 36,0967 & 2,2560 & $1,22^{\text {ns }}$
\end{tabular}

\begin{tabular}{lrrrr}
\hline (Tratam.) & 26 & 767,4433 & 29,5171 & $12,18^{* *}$ \\
Blocos & 1 & 22,5557 & 22,5557 & \\
Resíduo & 26 & 48,1493 & 1,8519 & \\
\hline
\end{tabular}

$M G=11,5722$

$s=1,3608$

$c v=11,76$

Análise de variância para teor de proteína bruta de haste

\begin{tabular}{lrrrr} 
C.V. & G.L. & S.Q. & Q.M. & F \\
Capim (C) & 2 & 12,1137 & 6,0569 & $2,79^{\text {ns }}$ \\
Idade (I) & 8 & 1148,2481 & 143,5310 & $66,15^{\text {ns }}$ \\
C.I & 16 & 48,6196 & 3,0387 & $1,40^{\text {ns }}$ \\
\hline (Tratam.) & 26 & 1208,9815 & 46,4993 & \\
Blocos & 1 & 40,0417 & 40,0417 & $18,45^{* *}$ \\
Resíduo & 26 & 56,4133 & 2,1697 & \\
\hline
\end{tabular}

$M G=8,4685$

$s=1,4730 \quad c v=17,39$ 
Tabela 35 - Análise da variância do fatorial, para teor de participação porcentual de proteína bruta de lâmina e de haste em relação à planta inteira, bem como os valores da média geral (MG), desvio padrão (s) e coeficiente de variação (cv)

Análise de variância para teor de participação porcentual de proteína bruta de lâmina em relação à planta inteira
c.v.
G.L.
S.Q.
Q.M.
F

- Capim (C)

2

$C \times I$

638,5233
4518,2400
263,7900

319,2617

- 564,7800

16,4869

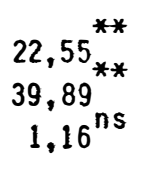

(Tratam.)

Blocos

8
16

16,4869

208,4828

172,0919

5420,5533

14,1595

$12,15^{* *}$

Resíduo

368,1481

$c v=6,86$

$M G=54,8778$

$s=3,7629$

Análise de variância para teor de participação porcentual de proteína bruta de haste em relaçào à planta inteira
C.V.
G.L.
S.Q.
Q.M.
F

Capim (C) 2

Idade (I) 8

643,8826

4545,0326

321,9413

568,1291

262,2641

16,3915

$$
\begin{gathered}
22,76^{* *} \\
40,17^{\text {** }} \\
1,16^{\text {ns }}
\end{gathered}
$$

$C \times I$

16

5451,1793

168,5400

209,6607

168,5400

14,1423

$11,92^{* *}$

Resíduo

16

367,7000

$M G=45,1037$

$s=3,7606$

$c v=8,34$ 
Tabela 36 - Análise de variância do fatorial, para os teores de conteúdo celular e fibra in solúvel em detergente neutro, bem como os valores da média geral ( $M G$ ), desvio padräo (s) e coeficiente de variação (cv).

Análise de variância para teor de conteúdo celular.

C.V.

Capin (C)

Idade (I)

$C \times I$

(Tratam.)

Blocos

Resíduo

G.L.

2

4

8

S.Q.

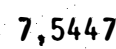

736,1433

51,3187
Q.M.

3,7723

184,0358

6,4148

\section{F}

$$
\begin{gathered}
1,12^{\text {ns }} \\
54,60^{\text {ns }} \\
1,90^{\text {ns }}
\end{gathered}
$$

$M G=22,6667$

$s=1,8360$

$c v=8,10$

\begin{tabular}{|c|c|c|c|c|}
\hline C.V. & G.L. & S.Q. & Q.M. & $F$ \\
\hline $\begin{array}{l}\text { Capim (C) } \\
\text { Idade (I) } \\
C \times I\end{array}$ & $\begin{array}{l}2 \\
4 \\
8\end{array}$ & $\begin{array}{r}7,5447 \\
736,1433 \\
51,3187\end{array}$ & $\begin{array}{r}3,7723 \\
184,0358 \\
6,4148\end{array}$ & $\begin{array}{c}1,12^{\mathrm{ns}} \\
54,60^{\mathrm{n}} \\
1,90^{\mathrm{ns}}\end{array}$ \\
\hline $\begin{array}{l}\text { (Tratam.) } \\
\text { Blocos } \\
\text { Resíduo }\end{array}$ & $\begin{array}{r}14 \\
1 \\
14\end{array}$ & $\begin{array}{r}795,0067 \\
0,5880 \\
47,1920\end{array}$ & $\begin{array}{r}56,7862 \\
0,5880 \\
3,3709\end{array}$ & $0,17^{\text {ns }}$ \\
\hline
\end{tabular}

$\begin{array}{r}56,7862 \\ 0,5880 \\ 3,3709\end{array} \quad 0,17^{\text {ns }}$

Análise de variância para teor de fibra insolúvel en detergente neutro

$M G=77,3333$

$s=1,8360$

$c v=2,37$ 
Tabela 37 - Análise de variância do fatorial e os respectivos desdobramentos, para o teor de fibra insolúvel em detergente ácido, bem como os valores da média geral (MG), desvio padrão (s) e coeficiente de variação (cv).

Análise de variância para teor de fibra insolúvel em detergente ácido

\begin{tabular}{lrrrr} 
C.V. & G.L. & S.Q. & Q.M. & F \\
Capim (C) & 2 & 37,7087 & 18,8543 & $11,51^{* *}$ \\
Idade (I) & 4 & 806,3833 & 201,5958 & $123,11^{* *}$ \\
C & 8 & 107,5047 & 13,4381 & $8,21^{* *}$ \\
\hline (Tratam.) & 14 & 951,5967 & 67,9712 & \\
Blocos & 1 & 1,8253 & 1,8253 & $1,11^{\text {ns }}$ \\
Resíduo & 14 & 22,9247 & 1,6375 & $\ldots .$.
\end{tabular}

$M G=46,9333$

$s=1,2796$

$c v=2,73$

Desdobramento de Idade dentro de Capim
C.V.
G.L.
S.Q.
Q.M.
1. $d$ C. 1
4
491,1500
1. $d C .2$
277,9640
122,7875
69,4910
1. d C. 3
144,7740
36,1935
$\mathbf{F}$

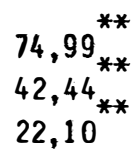

I. $d$ C.

(12)

$(913,8880)$

Desdobramento de Capim dentro de Idade

C.V. G.L. S.Q.

c. d I. 1

2

c. d I. 2

34,6800

c. d I. 3

14,4233

c. 1

49,6133

c. d I. 5

3,2433

43,2533

Q.M.

$F$

17,3400

7,2117

24,8067

1,6217

21,6267

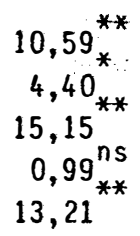

c. d I.

(10)

$(145,2133)$ 
Tabela 38 - Análise de variância do fatorial e os respectivos desdobramentos, para teor de hemicelulose, bem como os valores da média geral (MG), desvio padrão (s) e coeficiente de variação (cv).

Análise de variancia para teor de hemicelulose

C.V.

Capin (C)

Idade (I)

C X I

(Tratam.)

Blocos

Resíduo

$M G=30,4000$

G.L.

$$
2
$$

4

8

S.Q.

12,9680

25,1433

28,2087

14

1

14

$\begin{array}{rr}14 & 66,3200 \\ 1 & 0,3413 \\ 4 & 16,2387\end{array}$

$s=1,0770$

$c v=3,54$
Q.M.

6,4840

6,2058

3,5261

4,7371

0,3413

1,1599
F

$5,59^{* *}$

$5,42^{* *}$

3,04

$0,29^{\text {ns }}$

Desdobramento de Idade dentro de Capim

C.V. G.L. S.Q.

I. d C. 1

I. $d$ C. 2

I. d C. 3

(I. d C.)

(12)

17,9100

15,3760

20,0660

$(53,3520)$

Desdobramento de Capim dentro de Idade

$\begin{array}{lcccc}\text { C.V. } & \text { G.L. } & \text { S.0. } & 0 . M . & \text { F } \\ \text { c. dI. 1 } & 2 & 24,2233 & 12,1117 & 10,44^{\text {** }} \\ \text { c. dI. 2 } & 2 & 0,4433 & 0,2217 & 0,19^{\text {ns }} \\ \text { C. dI. 3 } & 2 & 9,7300 & 4,6850 & 4,19^{\text {ns }} \\ \text { c. dI. 4 } & 2 & 0,8100 & 0,4050 & 0,35^{\text {ns }} \\ \text { c. dI. 5 } & 2 & 5,9700 & 2,9850 & 2,57^{\text {ns }}\end{array}$

c. d I.

(10)

$(41,1767)$

Q.M.

4,4775

3,8440

5,0165

F

$3,86^{*}$

3,31 *

$4,32^{*}$ 
Tabela 39 - Análise de variância do fatorial e os respectivos desdobramentos, para o teor de celulose, bem como os valores da média geral (MG), desvio padrão (s) e coefi ciente de variação (cv).

Análise de variância para teor de celulose

C.V.

G.L.

S.Q.

Capin (C)

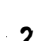

36,0080

Idade (I)

C $\times$ I

2

383,5487

50,4853

Q.M.

18,0040

95,8872

6,3107

$\therefore$

(Tratam.)

8

470,0420

Blocos

14

Resíduo

1

14

1,1603

10,4447

33,5744

1,1603

0,7460

$M G=40,2100$

$s=0,8637$

$c v=2,15$

Desdobramento de Idade dentro de Capim
C.V.
G.L.
S.Q.
Q.M.
$F$
I. $d$ C. 1
4
239,3260
59,8315
119,9140
29,9785
74,7940
18,6985
$80,20_{* *}^{* *}$
$40,18_{* *}^{* *}$
I. d C. 3
4
25,06

(1. d C.)

(12)

$(434,0340)$

Desdobramento de Capim dentro de Idade
c.v.
G.L.
S.Q.
Q.M.
c. d I. 1
2
32,0133
23,3233
c. d I. 2
24,5433
c. d I. 3
0,3733
c. d I. 4
6,2400
16,0067
11,6617
12,2717
0,1867
3,1200

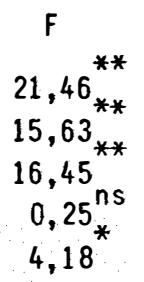

(c. d I.)

(10)

$(86,4933)$ 
Tabela 40 - Análise de variancia do fatorial e os respectivos desdobramentos, para teor de lignina, be m como os valores da média geral (MG), desvio padrão (s) e coeficiente de variação (cv).

Análise de variância para teor de lignina

\begin{tabular}{lrrrc} 
C.V. & G.L. & S.Q. & Q.M. & F \\
Capim (C) & 2 & 7,9927 & 3,9963 & $6,80^{* *}$ \\
Idade (I) & 4 & 99,6853 & 24,9213 & $42,39^{*}$ \\
C $x$ I & 8 & 17,7707 & 2,2213 & $3,78^{*}$ \\
\hline (Iratam.) & 14 & 125,4487 & 8,9606 & \\
Blocos & 1 & 0,0750 & 0,0750 & $0,13^{\text {ns }}$ \\
Resíduo & 14 & 8,2300 & 0,5979 & \\
\hline
\end{tabular}

$M G=6,7233$

$s=0,7667 \quad c v=11,40$

Desdobramento de Idade dentro de Capim
C.V.
G.L.
S.Q.
Q.M.
I. $d$ C. 1
4
54,9660
47,7300
13,7471
14,7600
11,9325
I. d C. 3
4
3,6900
$F$
$23.38_{* *}^{* *}$
20,30 *

(I. d C.)

(12)

$(117,4560)$

Desdobramento de Capim dentro de Idade
C.V.
G.L.
S.Q.
Q.M.
$F$
C. d I. 1
2
0,0533
1,9233
c. d I. 2
2
5,6233
0,0267
0,9617
$0,05^{\text {ns }}$
c. d I. 3
- 2
1,4700
2,8117
$1,64^{\mathrm{ns}}$
c. d I. 4
2
0,7350
$4,78^{*}$
c. d I. 5
16,6933
8,3467
$1,25_{* *}^{\text {ns }}$
$14,20^{* *}$

(c. d I.)

(10)

$(25,7633)$ 
Tabela 41 - Análise de variância do fatorial e os respectivos desdobramentos, para teor de digestibilidade "in vitro" da matéria seca, bem como os valores da média geral (MG), desvio padrão (s) e coeficiente de variação (cv).

Análise de variância para teor de digestibilidade "in vitro" da matéria seca it

c.v. G.L.

S. 0 .

Q.M.

Capim (C)

Idade (I)

2

4

$C \times I$

8

42,1807

2064,3387

79,6393

21,0903

516,0847

9,9549

$7,39^{* *}$
$180,83^{* *}$
$3,49^{*}$

\begin{tabular}{lrrrr}
\hline (Tratam.) & 14 & 2186,1587 & 156,1542 & $2^{* *}$ \\
Blocos & 1 & 26,8853 & 26,8853 & $9,42^{*}$ \\
Resíduo & 14 & 39,9547 & 2,8539 & \\
\hline
\end{tabular}

$M G=52,5933$

$s=1,6894$

$c v=3,21$

Desdobramento de Idade dentro de Capim
c.v.
G.L.
S.Q.
Q.M.
I. d C. 1
4
4
833,8800
822,6740
208,4700
1. d C. 2
487,4240
205,6685
I. d C. 3
4
121,8560

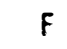
$73,05_{* * *}^{* *}$
$72,07 * *$
$42,70^{* *}$
(I. d C.)
(12)
$(2143,9780)$

Desdobramento de Capim dentro de Idade
C.V.
G.L.
S.Q.
Q.M.
$F$
c. d I. 1
- 2
29,4433
15,0433
c. d I. 2
73,0000
c. d I. 3
1,5100
c. d I. 4
2
2
c. d I. 5
2
2,8233

$$
\begin{array}{r}
14,7217 \\
7,5217 \\
36,5000 \\
0,7550 \\
1,4117
\end{array}
$$


Tabelá 42 - Análise de variância do fatorial, para os teores de fósforo, cálcio e magnésio, bem como os valores da média geral (MG), desvio padrão (s) e coeficiente de variação (cv)

Análise de variância para teor de fósforo

C.V.

G.L.

S.0.

O.M.

F

Capim (C)

2

0,0020

0,0010

Idade (I)

4

0,0451

0,0113

$C \times I$

8

0,0044

0,0006

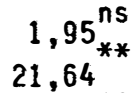

$1,06^{\text {ns }}$

\begin{tabular}{lrrll}
\hline (Tratam.) & 14 & 0,0515 & 0,0037 & $0,31^{\text {ns }}$ \\
Blocos & 1 & 0,0002 & 0,0002 & 0,0005 \\
Resíduo & 14 & 0,0073 & 0,005 & \\
\hline
\end{tabular}

$M G=0,1877$

$s=0,0228$

$c V=12,16$

Análise de variancia para teor de cálcio

C.V.

G.L.

S.Q.

Q.M.

F

\begin{tabular}{lrrrr} 
Capim (C) & 2 & 0,0426 & 0,0213 & $2,25^{\text {ns }}$ \\
idade (I) & 4 & 0,0305 & 0,0070 & $0,61^{\text {ns }}$ \\
$C \times I$ & 8 & 0,0827 & 0,0103 & $1,09^{\text {ns }}$ \\
\hline (Iratam.) & 14 & 0,1558 & 0,0111 & \\
Blocos & 1 & 0,0018 & 0,0018 & $0,19^{n s}$ \\
Resíduos & 14 & 0,1326 & 0,0095 & \\
\hline
\end{tabular}

$M G=0,7850$

$s=0,0973$

$c v=12,40$

Análise de variância para teor de magnésio

\begin{tabular}{lcccc} 
C.V. & G.L. & S.Q. & Q.M. & F \\
Capim (C) & 2 & 0,0276 & 0,0138 & $1,87^{\text {ns }}$ \\
Idade (I) & 4 & 0,0232 & 0,0058 & $0,78^{\text {ns }}$ \\
$C \times I$ & 8 & 0,0454 & 0,0057 & $0,77^{\text {ns }}$ \\
\hline (Tratam.) & 14 & 0,0962 & 0,0069 & $0,002^{\text {ns }}$ \\
Blocos & 1 & $-0,1037$ & $-0,0074$ & \\
Resíduo & 14 & $0,-$ &
\end{tabular}

$M G=0,4267$

$s=0,0861$

$c v=20,17$ 
Tabela 43 - Análise de variância do fatorial, para os teores de potássio, enxofre e da relação nitrogênio:enxofre, bem como os valores da média geral (MG), desvio padrão (s) e coeficiente de variação (cv).

Análise de variância para teor de potássio

\begin{tabular}{lcccc} 
C.V. & G.L. & S.Q. & Q.M. & F \\
Capim (C) & 2 & 0,8029 & 0,4014 & $4,36^{*}$ \\
Idade (I) & 4 & 5,1880 & 1,2970 & $14,10^{* *}$ \\
CXI & 8 & 0,4762 & 0,0595 & $0,65^{\text {ns }}$ \\
\hline (Tratam.) & 14 & 6,4670 & 0,4619 & \\
Blocos & 1 & 0,0053 & 0,0053 & $0,66^{n s}$ \\
Resíduo & 14 & 1,2880 & 0,0920 & \\
\hline
\end{tabular}

$M G=1,2440$

$s=0,3033 \quad c v=24,38$

Análise de variância para teor de enxofre

\begin{tabular}{lrrrr} 
C.V. & G.L. & S.Q. & Q.M. & F \\
Capim (C) & 2 & 0,0090 & 0,0045 & $9,21^{*}$ \\
Idade (I) & 4 & 0,0246 & 0,0061 & $12,577^{\text {ns }}$ \\
$C \times I$ & 8 & 0,0039 & 0,0005 & $0,99^{2}$ \\
\hline (Tratam.) & 14 & 0,0374 & 0,0027 & $6,55^{*}$ \\
Blocos & 1 & 0,0032 & 0,0032 & \\
Resíduo & 14 & 0,0068 & 0,0005 & \\
\hline
\end{tabular}

MG $=0,1237$

$s=0,0221$

$c V=17,83$

Análise da variância para relação nitrogênio:enxofre

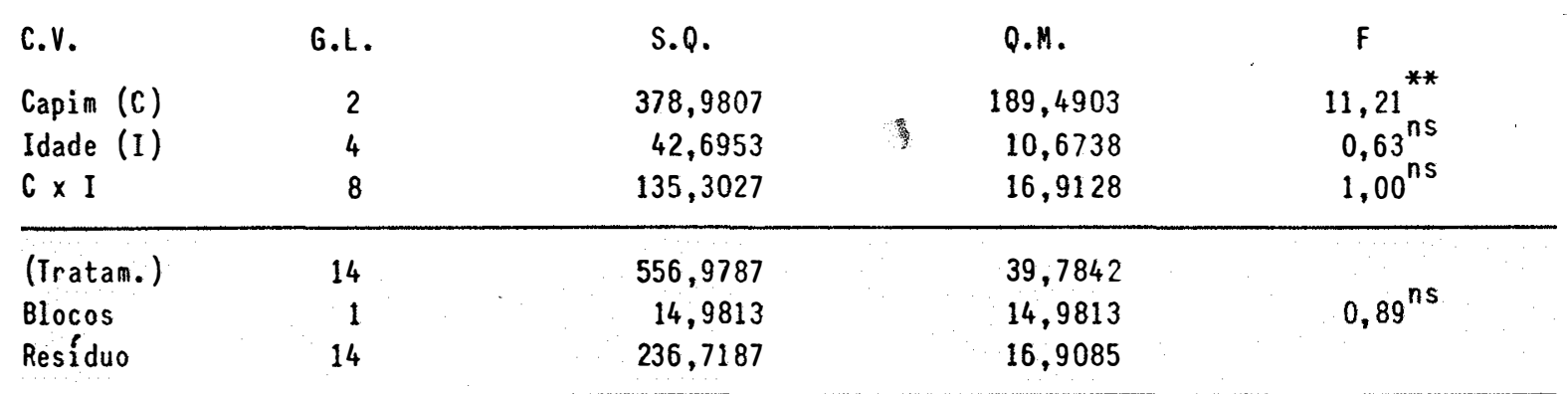

NG $=19,4267$

$s=4,1120$

$c v=21,17$ 
Tabela 44 - Análise de variância fatorial, para os teores de cobre e ferro, bem como os valores da média geral (MG), desvio padrão (s) e coeficiente de variação (cv).

Análise de variância para teor de cobre

c.v.

Capim (C)

Idade (I)

$C \times 1$

(Tratam.)

Blocos

Resíduo

NG $=6,1667$
G.L.

2

4

8
S.Q.

0,8667

148,0000

11,8000

160,6667

14,7000

24,8000
Q.M.

0,4333

37,0000

1,4750

\section{F}

$0,24^{\text {ns }}$ $20,89^{* *}$ $0,83^{\text {ns }}$

11,4762

14,7000

1,7714

Análise de variância para o teor de ferro

C.V.

Capim (C)

Idade (I)

C X I

(Iratam.)

Blocos

Resíduo

$M G=379,1000$
G.L.

\section{2}

4

8
S.Q.

16038,2000

1636869,8667

140647,1333

1793553,2000

997,6333

226259,8667

$c v=21,58$

$8,30^{*}$

$s=1,3310$

21,58 
Tabela 45 - Análise de variância do fatorial, para os teores de manganês e zinco, bem como os valores da média geral (MG), desvio padrão (s) e coeficiente de variação (cv).

Análise de variância para teor de manganês

\begin{tabular}{lrrrr} 
C.V. & G.L. & S.Q. & Q.M. & $F$ \\
Capim (C) & 2 & 6304,2000 & 3152,1000 & $1,31^{\text {ns }}$ \\
Idade (I) & 4 & 7962,4667 & 1990,6167 & $0,83^{\text {ns }}$ \\
CXI & 8 & 6377,1333 & 797,1417 & $0,33^{\text {ns }}$ \\
\hline (Iratam.) & 14 & 20643,8000 & 1474,5571 & $0,69^{\text {ns }}$ \\
Blocos & 1 & 1657,6333 & 1657,6333 & \\
Resíduo & 14 & 33658,8667 & 2404,2048 & \\
\hline$G=230,3000$ & & $S=49,027$ & CV $=21,29$ &
\end{tabular}

Análise de variância para teor de zinco

C.V.

G.L.

S.0.

Q.M.

$\mathrm{F}$

Capim (C)

Idade (I)

$\mathrm{C} \times \mathrm{I}$

2

4

8

264,4667

446,4667

168,5333

(Tratam.)

Blocos

Resíduo

14

1

14
879,4667

19,2000

222,8000
132,2333

111,6167

21,0667

62,8190

19,2000

15,9143

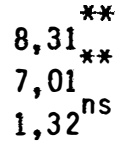

$1,21^{\text {ns }}$

$M G=23,1333$

$s=3,9893$

$c V=17,24$ 